\title{
SURVEY OF THE ARCHAEOLOGICAL LANDSCAPE OF UŞAKLI / KUŞAKLI HÖYÜK (YOZGAT)
}

\author{
S. Mazzoni, A. D’Agostino, V. Orsi
}

\section{INTRODUCTION (S. Mazzoni)}

In 2008 and 2009 thanks to the kind approval of the Directorate of Cultural Heritage and Museums of Turkey $^{1}$ a new archaeological survey was started by the University of Florence $^{2}$ on the site of Uşaklı/Kuşaklı Höyük and its surrounding area, a wide plain north-west of the Kerkenes Dağ watered by the Egri Öz Su.

The site is clearly visible from the route connecting Yozgat and Sivas (fig. 1), emerging in a wide plain defined to the south by the Kerkenes Dağ. It had already been visited by E. Forrer in 1926 (Forrer 1927: 33), by H.H. von der Osten (von der Osten 1929: 37, 38, Figs. 31-32) in the following year, and later by P. Meriggi (Meriggi 1971: 62, Pl. X.1-2), and recorded under different names: Kusachakly (Forrer), Kuşaklı (von der Osten) and Uçaklı (Meriggi). ${ }^{3}$ On the old maps of the land register of Sorgun, the site is clearly marked as Uşaklıhöyük; ${ }^{4}$ however, the name of Kuşaklı Höyük prevailed in the literature and the höyük is listed with this name in the Yozgat catalogue of archaeological sites of the region. In order to avoid confusion with Kuşakl1/Sarissa we will use Uşakl1/Kuşaklı Höyük.

\footnotetext{
${ }^{1}$ We wish to express our sincere gratitude to the Director of the General Directorate of Cultural Heritage and Museums, Orhan Düzgün, to the Director of Excavations, Gökhan Bozkurtlar, and his staff for their invaluable support. We are truly grateful also to Erkan Yilmaz, of the Museum of Aydin and Emel Özçelik of the Museum of Eskişehir, who gave us gracious and wise assistance, and to Director of the Yozgat Museum, Hasan Senyurt for his kindness. We thank the Sorgun District Governor, the Ilçe Kaymakani, Ertugrul Kiliç and the Military Head Commander of Sorgun, the Ilçe Jandarma Komutani, Hakan Öztürkmen for their kind welcome and aid during our staying in the region. The guardian of the Kerkenes house, Mehmet Ergiyas, and the Muhtar of Sahmuratl, Osman Muhratdagi, made our stay there easy in every way. Special thanks are due to Murat Akar, PhD student at Florence, and Ekin Demirci, student at the Bilkent University, who worked with us in the field and provided their valuable help on many questions. We are indebted to Prof. Tangianu, Director of the Istituto Italiano di Cultura for her support and interest. Financial support for this campaign has been granted by the University of Florence and the Foundation OrMe, Oriente Mediterraneo.

${ }^{2}$ Director: S. Mazzoni; archaeologists: A. D’Agostino, V. Orsi, B. Chiti, M. Akar; epigraphers: G. Torri, C. Corti; topographers and geomagnetic surveyors: G. Carpentiero, E. Mariotti; geomorphologists: R. Salvini, A. Cartocci, M.C. Salvi; draughtsman: S. Martelli; students: G. Della Lena Guidiccioni; E. Demirci, F. Barsacchi, M. Di Marcoberardino, D. Fossati, R. Ranieri, W. Bucci, F. Longo.

${ }^{3}$ See Summers 1995: 53-55.

${ }^{4}$ We thank our 2009 representative, Emel Özçelik, who made enquiries of the communal authorities which own old maps of the land register.
} 
The first archaeological survey of Uşakl1/Kuşaklı was carried out by G.D. and M.E.F. Summers in 1993-1994 in the framework of the Kerkenes Project. ${ }^{5}$ They were able to provide for the settlement a date which includes both the $2^{\text {nd }}$ and $1^{\text {st }}$ millennia B.C. with a main floruit in the Hittite period, on the basis of a preliminary surface collection of pottery. A few blocks in the lower terrace, apparently in situ, were recognised by von der Osten, and later on by Meriggi and Summers as belonging to a gate and documenting a not insignificant Hittite phase. Summers also attributed to the site a well dressed granite slab now in the garden of the mosque in the nearby village of Aşağı Karakaya Köy. A further important document associated with Uşakl1/Kuşaklı Höyük is a Hittite tablet which is said to have come from Taşl1k Höyük, a small mound of LC and EB periods, 2 km SW of Uşaklı/Kuşaklı. ${ }^{6}$

O.R. Gurney suggested that this settlement could be Zippalanda (Gurney 1995: $69-71),{ }^{7}$ because it lies about $30 \mathrm{~km}$ as the crow flies to the north of Alişar Höyük, which had already been identified with Ankuwa by I.J. Gelb. ${ }^{8}$ Textual sources place Zippalanda two or three days (in two different itineraries) from Hattuša (which lies nearly $43 \mathrm{~km}$ to the north). According to the Spring festival, the Hittite king worshiped Mount Daha, the seat of a Storm God, after having reached Zippalanda, and moving to Ankuwa. A good candidate for this mountain is, therefore, Kerkenes Dağ, as Gurney pointed out.

Against this background, our new survey is primarily directed towards exploring intensively the site and its catchment area and obtaining clear information on its historical development. At the same time, it aims to gather evidence on the settlement pattern of the plain over a long duration and examine its environment and economic background. Distinct and coordinated archaeological, topographic, geophysical and geological surveying operations have been consequently organised in the first two years of the research.

The survey was conducted in a very limited area of the south-western region of the province of Yozgat, dominated by granitic cliffs and mountains, rich in springs and water, especially to the south of the river Egri Öz Dere, which flows from WNW to E, and south of the highway which today links the towns of Yozgat and Sorgun. Uşakl1/Kushakli Höyük is located in the southern and western part of a quite large plain limited to the N by the Egri Öz Dere (fig. 2). The höyük lies on the southern bank of the river in a large recess shaped by the meandering course of this stretch of the river. The plain is limited to the N by gentle hills ; to the NW can be seen the mountains bordering Hattuša which are crossed by a network of rivers providing clear route alignments along the bottom of the valleys. The high and distinct profile of Kerkenes Dağ marks the

\footnotetext{
${ }^{5}$ Without the initial encouragement and support given to the application by G.D. and M.E.F. Summers and their generous scientific guide, our work would not have reached its goal. No less appreciated by our team was their hospitality in the Kerkenes Mission house which made our stay a fully enjoyable experience. See Summers, Summers and Ahmet, 1995: 43-68.

${ }^{6}$ On the tablet see Summers, Summers and Ahmet 1995: 55.

${ }^{7}$ In a religious festival the Hittite king, moving from Hattusha, reached Haitta and Mount Puskurunuwa. From there, the king arrived on the third day in Zippalanda, where he worshiped Mount Daha (probably Kerkenes Dağ). The next day, he reached Ankuwa.

${ }^{8}$ For the debate on the identification of Ankuwa, see Gurney 1995: 70, note 9.
} 
southern skyline of the landscape; the mountain can be easily reached from Uşakl1/Kuşaklı Höyük through two wide N-S valleys running parallel on the east, while to the west and south there are instead deep gorges rich in natural springs and small watercourses, such as the Kötü Dere, a SW tributary of the Egri Öz Dere.

The survey is currently concentrated on a triangle of the NW sector of the regional survey of the Kerkenes Project conducted by G. Summers. To the S of this area a regional survey was undertaken by S.A. Branting in the area of Alişar Höyük in the framework of an excavations project begun in 1993 in Alişar Höyük and in the nearby Çadır Höyük by R.L. Gorny (R.L. Gorny 1994, 1995; Branting 1996). To the NW the regional survey of Büyüknefes-Tavium by K. Strobel and Ch. Gerber covers an extended area to the $\mathrm{N}$ and NE of Yozgat (Strobel, Gerber 2007a, 2007b); a further survey concentrated on the routes linking the area with Hattusha and the site of Yassihüyük and its catchment by M.F. Fales, St. de Martino S. Ponchia and M. Luciani (Fales, De Martino, Ponchia, Strobel 2009). These regional investigations were able to provide evidence of a steady occupation of the area from the Late Chalcolithic/EB I period on, with a substantial increase during the Hittite and Iron Age periods and a final floruit in the Byzantine period.

\section{GeOLOGY OF THE AREA (R. Salvini)}

The geology of the area is the result of the collision of Eurasian and AfricanArabian plates which began more than 100 million years ago with the closure of the ancient Tethys Sea. The collision created mountain ranges and valleys as well as provoking volcanic activity and intrusion of igneous granitic rocks. Plate movements produced numerous faults that bound large areas, the continuation of which explains the susceptibility of Anatolia to earthquakes.

The granitic rocks were formed kilometres beneath the earth's surface where the collision of plates caused the crust to thicken. Great pressure and temperatures at these depths began to melt the rocks of the continental crust. The resultant magma was forced up through fractures and accumulated, forming granitic rocks as it slowly cooled. The study area lies along the Alpine-Himalayan system within the Central Anatolian Crystalline Complex or CACC (Erler and Göncüoğlu 1996), an assemblage of magmatic, metamorphic and ophiolitic rocks highly fractured by continuous deformation since the Upper Cretaceous.

The granitic rocks, present mainly in the southern part of the area, intruded older Paleozoic-Mesozoic metamorphic rocks and late Cretaceous mélange units, and are overlain by early Tertiary volcanics, clastics, coal and carbonates. To the north, Miocene evaporites and clastics and Plio-Quaternary clastics are the youngest cover rocks of the region mainly represented by sandstones, marls, conglomerates and breccia.

The distribution of rock units in the region is mostly caused by the NE-SW trending faults. Fractures are easily recognised on the surface because they have a high moisture content that creates linear growths of grass. Water resources are also controlled by faults and fracture systems. Springs have formed at intersections of fault or fracture planes along which water can easily rise upwards. To the south-west of the area granitoids 
were uplifted by these faults and they occupy topographically high erosional areas, such as ranges or hills. The cover units occupy low depositional areas and are not resistant to erosion.

The primary minerals of granitic rock are plagioclase, K-feldspar, quartz, pyroxene and hornblende. Besides primary minerals in various proportions, other minerals can be identified such as biotite and chlorite.

The highest elevations of the area are in the north-western neighbourhoods of Islegen (above $1,300 \mathrm{~m}$ ). The lowest measured point is north-west of Babali $(1,146 \mathrm{~m})$. The site of Uşaklı/Kuşaklı Höyük lies within a simple drainage basin that consists of one main stream, running WNW-ESE with small tributaries.

Talus of blocks of granitoids at the foot of the hills, alluvial fans of gravel to sandsized fragments of rocks along topographic breaks, alluvium along tributaries and the main stream, and soil on gentle slopes constitute the main depositional features of this area.

\section{Fieldwork activities}

The geologic-geomorphologic survey was conducted over an area of about 90 square kilometres around the mound of Uşaklı/Kuşaklı Höyük (the big triangle in figures 3 and 4) during August-September 2009.

The geomorphologic study involved the geological survey and GPS measurement of rock outcrops and morphological features (133 stops) (fig. 3).

A multispectral GeoEye stereo image pair, $0.50 \mathrm{~m}$ ground resolution, were acquired on September $25^{\text {th }} 2009$, with the aim of creating, from the stereoscopic digital restitution, a topographic map of the Uşaklı/Kuşaklı Höyük area on a scale of 1:10,000, a Digital Terrain Model (DTM) and a geomorphologic map.

The survey involved 132 GCP, spatially well-distributed around the area (Figure 2) and related to 9 purpose-built reference stations (south of Kababel village, north of Karakaya Köy, west of Dişli, Inceçayır, Kuşaklı Höyük, Karakaya Köy, north of Işleğen, Kuçuk Taşlik, west of Babalı) (fig. 4). Thanks to the director of the Kerkenes Mission, coordinates and description cards of 3 reference points were made available (Atalan et alii 2008). Moreover, additional trigonometric points were acquired at the Harita Genel Komutanlığ 1 - Geodezi Dairesi Başkanlığı of Ankara.

\section{INFORMATION FROM THE SURFACE: THE TOPOGRAPHICAL SURVEY (E. Mariotti)}

The survey on site took place in different working sessions during two campaigns (2008-2009): the topographical survey involved the whole site (the höyük and its valley) and the surrounding area, for a total surface of 50 ha with 43,000 topographical points recorded. The entire extension of the settlement is about 10 ha, while the central mound covers an area of 2 ha. The measurements were taken at the mean distance of $1 \mathrm{~m}$ along linear paths, following the natural morphology of the soil (2008).

The interpolation of measured points from survey generates a 3-Dimensional model: the surface is represented homogeneously and can be read in its realistic shape. An 
initial interesting result come from examination of the contour line layout: the plateau of the lower city, in spite of the apparent uniformity of the surface, is actually characterised by two clearly distinct areas identified by the different orientation of the isoipses (figs. 5 and 6). They might represent two urban districts serving different functions: the eastern one could be linked to a public area or to the acropolis itself (area A), the other one (area B) probably playing a more general role in the communal life of the site. The eastern part is characterised by huge structures, which have determined the current morphology of the terrain (as clearly visible from the results of geophysical survey); the western and northwestern part with a larger extension of about 3 ha is characterised by a low depression and, along its northern and southern limits, shows what could be a gate and a defensive rampart.

These structures, although still hypothetical, can be determined from the $3 \mathrm{D}$ model (fig. 6): the north-western edge of the lower city presents two bumps with a central depression at the very limit of the slope that could be identified as the wall rampart. Examining its shape and position we can assume the presence of a gate flanked by defensive structures (towers or small ramparts). The central gully on the surface could represent the passage through the entrance. Seen from the digital model the whole complex seems to be of remarkable size (about $65 \mathrm{~m} \times 20 \mathrm{~m}$ ), which is probably also determined by collapses and later stratification. It is not possible to estimate the exact width of the gate; we can only note that the more clearly visible point of the depression (and its related isoipses) is about $5 \mathrm{~m}$ wide. This position is certainly of strategic importance both from a tactical and an urban point of view, near the limit where the lower city turns towards the south. In similar cases fortifications show several vulnerable sides facing outwards which, for precisely this reason, are normally provided with defensive structures, such as ramparts and towers. This is the reason why gates and access roads are provided with the same structures. Similar considerations can be applied to strategic and defensive techniques of both Classical and Hellenistic features as well as Hittite fortifications.

The Digital Elevation Model shows other characteristics, such as: a) the central part of the western valley is crossed by a slight linear dip, coming from the structures described above; the path ends at the limit of the tell, in the southern part of the area, where another similar dip is visible; b) the south-western corner of the valley is higher than the surrounding area, creating a bump and a significant external slope. The hypothesis concerning the presence of a huge defensive structure in this place seems to be confirmed by the presence of large square blocks with well-shaped corners. We cannot rule out the presence of another eastern entrance, in a protected and tactical position; c) in the extra-urban region there are some interesting prints, visible in the north-western area, which is in a lower position than the rest of the valley and the surrounding fields: the mark running south-west/north-east, visible in the surveyed surveyed sector, ${ }^{9}$ could be identified as a paleo-riverbed or a marsh area during the wet-season.

\footnotetext{
${ }^{9}$ The modern road and the river with trees on its banks have hindered a wider survey. Nevertheless this is the only part of the site which seems to have maintained its geomorphologic patterns.
} 
Technical information:

1. total surface surveyed: approximately 30 ha;

2. total points recorded: 42,000 ;

3. extension of the terrace: circa 7 ha;

4. extension of the central mound: circa 2 ha

5. elevation: $1116-1136 \mathrm{~m}$ above sea level;

\section{First RESUlts of GeophysiCAL Survey (G. Carpentiero)}

The first two campaigns of geophysical prospection concerned the northern and eastern part of the terrace at Uşaklı/Kuşaklı Höyük.

The main aims of the survey were to recognize the topography of the site and the urban organization of the city, to identify road networks, districts, the circuit of walls and, finally, the extent of the settlement. The area for the geophysical prospection was chosen in order to investigate a part of the lower city which seemed the most accessible for data acquisition.

With the aim of integrating different kinds of geophysical prospection with other survey methodologies, magnetic surveying was undertaken together with a geoelectric survey, while the topographical survey with DGPS (Differential GPS) was carried out alongside the surface survey on the same grid as the geophysical prospection. The integration of different methods is necessary as geophysical data furnish a onedimensional image of buried structures. Systematic collection of pottery sherds and other materials helps to outline the diachronic development of the settlement and, where possible, to identify the function of different structures (Keay 2000: 6).

\section{Magnetic survey (fig. 7)}

The acquisition of magnetic data on the site of Uşakl1/Kuşaklı Höyük has been carried out using a Fluxgate Gradiometer FM36 (Geoscan Research), a model of magnetometer which has two sensors stacked vertically $0.5 \mathrm{~m}$ apart and which records the differences between their readings. It was chosen also because of its practical suitability for covering a large area in a relatively short time.

This method is particularly effective as it can be carried out rapidly before further geophysical investigations. In 11 days work (9 days in 2008 and 2 days in 2009) an area of 3.68 hectares was investigated, divided into a regular grid of 92 squares. The dimension of each square was established as $20 \times 20 \mathrm{~m}$ and the measurements were taken every $0.50 \mathrm{~m}$ (sample interval) with $1 \mathrm{~m}$ traverse interval for a total of 73,600 readings. The acquisition was made with parallel mode (instead of zig zag) in order to reduce field errors and noise such as that produced by grid edges and striping of traverses. Fluxgate sensors are relatively sensitive to changes in survey direction as they measure the vertical component of the total magnetic field. The field accessories such as measuring tapes and wedges were made of non-magnetic materials. The gradiometer sensitivity was set to $0.1 \mathrm{nT}$. 
After the acquisition Geoplot Software (Geoscan Research) was used to download and process the gradiometer data with different functions, such as zero mean grid, zero mean traverse, low pass filter and clipping. The result was a shade plot map in greyscale as visible in the table.

\section{Geoelectric Resistivity survey (fig. 8)}

An RM15 Resistance Meter (Geoscan Research) was used for the electrical resistance survey at Uşakl1/Kuşaklı Höyük over the north-eastern edge of the area, already surveyed the year before by magnetic methods. The survey was carried out in 20 by $20 \mathrm{~m}$ grids with a sampling strategy of readings every $0.50 \mathrm{~m}$ at $0.50 \mathrm{~m}$ traverse intervals in zigzag mode. This kind of horizontal surveying enables us to determine the location of artefacts and features by observing the distribution of relative electrical relative resistance and attempting to infer the nature of the anomalies from their shape, size, position and strength.

Data was collected for a total of 26 grids covering an area of 10,400 square metres, a little over one hectare. Results were of greater clarity than the data obtained from the magnetic survey alone.

\section{Preliminary results and interpretation}

With the help of the geophysical survey completely new structures were detected and numerous new details perceived. A positive result was that we were able to verify that the two methods detect different sorts of anomalies that can be integrated with each other. This effect depends on the nature of the construction material, the surrounding soil and state of conservation. For this purpose it is interesting to note the different data obtained with the two methodologies: the structures visible during the magnetic survey are invisible in the geoelectric and vice versa.

The overall impression gained from the combination of the results obtained from the two kinds of prospection is that all the structures are oriented in the same direction (northwest-southeast), except those on the slope in the southern part of the prospected area probably influenced by local topography. We are also able to identify four particular areas of interest.

The first (A) indicates the presence of a huge defensive structure on the northwestern side of the surveyed area connected with the system of bumps and gullies already visible from the topographical survey (see above: Mariotti). In particular the magnetic survey locates a marked anomaly arising from a structure subjected to severe heating (probably burned by fire) as visible in the greyscale shade plot map (fig. 9).

Moving east, another large structure (B) is clearly visible when we combine resistivity and magnetic data. This covers an area of approximately 50 by $40 \mathrm{~m}$ with several rooms probably around a court. In this case the resistivity survey was much more effective than the magnetic one which did not yield such good results.

In the north-east corner of this area there is a structure clearly visible from magnetic survey as it was probably heated by fire (fig. 7) with two pairs of rooms on 
either side of a small passage and another anomaly probably to be identified as the two walls of a city wall circuit.

The third large structure $(\mathrm{C})$ is located south of the second. Here we can clearly discern the presence of 4 long rooms that can be interpreted as store rooms and some other large rooms underneath, all flanking a possible road that led from the "gate" to the city core.

The last large complex of anomalies singles out the presence of two long walls bordering the slope and other structures not homogenously orientated. On initial analysis these could be interpreted as the city walls and the structures outside in the suburbs. All the small round anomalies could be kilns or other productive structures.

\section{SURVEYING MATERIALS AND ARCHITECTURE (B. Chiti)}

The collection of surface materials conducted on the Uşakl1/Kuşaklı Höyük site during the 2008-2009 campaigns involved a total surface area of 29,151 $\mathrm{m}^{2}$, divided into 6 different areas ${ }^{10}$ situated on the terrace and the northern and south-eastern slopes of the lower terrace (fig. 10), where architecture remains are exposed and sherds are abundant on the surface. For the acquisition of the prospecting data (archaeological, geomagnetic and geoelectric), a 20x20m-square grid was constructed, ${ }^{11}$ inscribing the site in a $500 \times 380 \mathrm{~m}$ rectangle. In the areas involved in the collection, the squares were in turn subdivided into smaller squares of $5 \times 5 \mathrm{~m}$, so as to facilitate the localization of the finds. The south-eastern slope of the lower terrace was instead divided into lots and bands following the present system of agricultural division and morphology of the land. Diagnostic pottery was then surveyed by means of total station (Leica TCR407 Total Station).

Mapping surface architecture was a further goal of the project, beginning with the large-sized stones (Structure 1) on the eastern side of the lower terrace (figs. 11), already identified in the course of the preceding surveys as a Hittite gate. ${ }^{12}$ These remains appear to have been greatly altered since their first discovery. Nine blocks of granite are actually on the surface and apparently in situ, ${ }^{13}$ carefully worked and arranged on two parallel staggered segments. These segments are both orientated along the SE-NW axis and stretch along a total line of about $10 \mathrm{~m}$. Despite the absence of an effective connection between the two alignments, the original " $Z$ " shape of the structure can still be made out.

The distinct granite used for the blocks seems to have been quarried in an outcrop $2 \mathrm{~km}$ away, as the geological survey was able to detect. ${ }^{14}$ Both the use of special building material and the size of the blocks attest to the monumental nature of the original building. As regards the relation of these stones to the buildings identified by the geomagnetic and

\footnotetext{
${ }^{10}$ During the 2008 campaign collecting was conducted over a total surface of $13,508 \mathrm{~m}^{2}$, whereas in 2009 the surveyed surface area was $15,643 \mathrm{~m}^{2}$.

${ }^{11}$ The squares were denominated according to a system of letters along the N-S axis, and of numbers along the E-W axis.

${ }^{12}$ See above, footnote 3. Note the preservation of the stones in Meriggi 1971, Pl. X.2.

${ }^{13}$ Another twenty of so large or medium sized blocks, probably belonging to this structure, can be recognised in the area.

${ }^{14}$ Salvini, this article.
} 
geoelectric surveys ${ }^{15}$ (figs. 7 and 8 ) in this eastern area of the terrace (consisting of two large and regularly planned buildings and, close to the slope of the terrace, a fortification system), we can only say that their position and orientation fit better with the southern building (fig. 10) rather than the supposedly defensive wall. Thus, if Structure 1 were a gate, it might have been the entrance to this building.

Other groups of stones and individual stones were also observed and mapped in the 2009 campaign. These offer evidence of the presence of probably quite long-lasting buildings in the höyük, which can be assigned to the Hittite period on the basis of the cutting and polishing techniques employed. In particular, three large-sized and well dressed blocks are worked on the external surface with a square groove in correspondence with one of the corners (fig. 5). Stone 2 is the biggest ${ }^{16}$ and is situated on an elevation on the south-western side of the terrace but is most probably out of place (fig. 12). This stone, which is of a different type of granite ${ }^{17}$ than the blocks of Structure 1, shows a carving technique which is probably Hittite. The other two stones displaying the same carving technique are much smaller in size. Stone 3 is situated on the western boundary of the höyük, at the edge of the road, and seems to be still in situ, whereas Stone 4 is situated to the south and seems to have been moved from its original place.

Moreover, it was from the interpretation of geomagnetic and geoelectric data that we were able to obtain important information concerning the nature and the typology of the detected remains.

On the north-eastern slope of the terrace a series of rectangular rooms has been identified, irregularly aligned, forming a "saw-tooth" profile, that can be interpreted as a casemate of a city fortification line. The typology, the dimensions, ${ }^{18}$ and especially the "saw-tooth" alignments of these rooms allow us to establish a comparison with the fortifications of the Hittite period attested at Alişar Höyük (von der Osten 1937: 4-10).

Furthermore, on the geomagnetic plan a large rectangular structure (fig. 7) could clearly be observed on the north-eastern slope, consisting of a passage, that measures at least $2.4 \mathrm{~m}$ in width, flanked by two quadrangular constructions composed of small rooms. This structure is perhaps to be identified as a city gate equipped with towers. Although the typology of this gate is to be found in Hittite architecture, both the interior tripartite subdivision and the unusual width $(13 \mathrm{~m})$ of the eastern tower prevent us from finding any precise parallels ${ }^{19}$.

\footnotetext{
${ }^{15}$ Carpentiero, this article.

${ }^{16}$ This stone had already been identified during a preceding survey (Summers, Summers and Ahmed 1995: 56).

${ }^{17}$ Salvini, personal communication.

${ }^{18}$ The rooms measure 2.4 to $3.6 \mathrm{~m}$ in length.

${ }^{19}$ At Alaça Höyük, Alişar Höyük, Kuşakl1-Sarissa the city gates are equipped by towers with an interior bipartite subdivision, the dimensions of which indicate standardisation, that is 9 to 10m in length (Koşay 1966: 124-125; von der Osten 1937: 4-10; Schachner 1998: 129-135; Schachner 1999: 69-79; Mielke 2004: 146-157).
} 
The two large constructions ${ }^{20}$ detected by the geoelectric survey (fig. 10) are both situated on the north-eastern area of the lower terrace, the one indicated as Building I close to the north-eastern city gate, and the other one, called Building II, to the south-east of the former.

The number of rooms ${ }^{21}$ that seems to compose the buildings, but primarily their considerable dimensions (Building I: around $710 \mathrm{~m}^{2}$; Building II: around $875 \mathrm{~m}^{2}$ ), strongly suggest a public rather than a domestic destination.

From their plan, these two structures reveal very different characteristics. While Building I has a quite a regular arrangement, inscribed in a $25 \times 28 \mathrm{~m}$ rectangle, Building II shows a mostly irregular plan that seems to be the result of the juxtaposition of different blocks. The north-western one can be seen particularly clearly on the geoelectric plan. Here is possible to distinguish four long and narrow parallel rooms, which recall the storage rooms of the palaces of Alaça Höyük and especially the four rooms of the northern wing of the level III palace at Maşat Höyük (Özgüç 1982: 73-76). ${ }^{22}$ Given these comparisons, Building II might be part of a palatial complex.

Building I instead does not show in plan any distinct characteristics that could indicate its nature or typology. Nevertheless, it can be observed that its eastern external wall seems to be parallel to the fortification line, suggesting that they might belong to the same phase.

\section{Collecting Method (A. D’Agostino)}

Systematic investigations have so far concerned the large extended terrace at the foot of the high mound. The survey was focused on the NE and W portions of the terrace and its E-SE low, slightly sloping base, where buried walls and structures have been identified with geomagnetic and resistivity recognition. An intensive sampling strategy of all the artefacts relating to the main topographical or surveyed units was at first aimed at achieving precise spreadsheets of the different categories of finds. As is generally known, the means of estimating the size of a multi-period site in each period of occupation is a systematic collection of all the artefacts, directed towards achieving precise spreadsheets of the different categories of finds. Through the analysis of spreadsheets we are able to understand if there is a differentiation in the distribution pattern of different categories of artefacts and hence infer chronological and functional information. Obviously, there are limits in putting the theory into practice. We have to say that serious limits to a correct understanding of the initial local of artefacts, the original distribution and composition of the archaeological record are posed by post-depositional activities such as human intervention and natural events. In particular, previous visits to the site and collections

\footnotetext{
${ }^{20}$ The limits of each building have been defined on the basis of orientation and morphological and metrical coherence of remains detected.

${ }^{21}$ In building A at least 10 rooms could be identified, and at least 13 in building B.

${ }^{22}$ At Maşat Höyük rooms are larger and measure 17x3m, at Kuşaklı Höyük around 9x1.80m.
} 
carried out in past years, intense agricultural activities and erosion could have resulted in quite marked modifications of the original location of the artefacts and their consistency. ${ }^{23}$ In the case of Uşakl1/Kuşaklı Höyük these factors are all documented and observed.

It would, in fact, be more correct to define our activity as a sort of 're-surveying' of the site first covered by unsystematic explorations conducted by travellers and scholars and, in recent times, by American and British colleagues. The collections of surface sherds carried out by O.R. Gurney (1995: 69-72) and then by G.D. and M.E.F. Summers, in the framework of the Kerkenes Dağ Survey Project (Summers et alii 1995: 53-59), provided us the first organised pieces of information concerning the main phases of occupation. These first data collections were able to document that the major period of occupation was the $2^{\text {nd }}$ millennium $\mathrm{BC}$, followed by a later occupation (Iron Age, including Achaemenid up to the Roman/Byzantine periods) mainly involving the high mound and portions of the lower terrace, the limits of which have not yet been established.

Keeping this in mind, and conscious of possible bias in the displacement of artefacts, we decided to start the intensive collection, even though the disposal and concentration of sherds could only provide us with a map of areas in which the reliability of the deposit had to be verified by statistical analysis, separating the deposit coming from the buried strata of the deposit caused by disturbance. We should also note that the intensive collection strategy applied could in part also help reduce the disadvantages resulting from reduced visibility factors. In fact, the presence of relatively dense vegetation (residuals of the crop season, ears, stems and dry straw as well as some herbaceous plants) covering most of the terrace during the 2008 campaign partially reduced the visibility of the soil. We decided to partially clear each square of vegetation with the use of rakes, being careful not to remove sherds or other artefacts: in so doing, the heap of vegetation removed was also examined for possible sherds unintentionally dug up. This method was applied to of the single collecting units. During the 2009 campaign, the increased visibility due to the absence of cultivation residues and to recent ploughing activity over a large portion of the lower terrace, facilitated the collection of sherds and made our task both easier and quicker.

The collection was carried out on three separate portions of the flat surface constituting the top of the terrace and its low slope that gradually descends to the valley floor. Only a handful of noteworthy sherds were gathered from other sectors of the site, in particular on the slope of the high mound, and located on the map with the total station.

Our field method involved sampling survey units established on the basis of morphological characteristics and following, on the flat areas, the general topographical grid. The method applied was based on dividing up the surface into squares or irregular discrete units from which all the artefacts and diagnostic sherds were collected. The intensive collecting involved full coverage of 39 squares of $20 \times 20 \mathrm{~m}$ and 6 survey sectors on the low slope, leading off the terrace limit fanwise (fig. 13). As regards the top of the

\footnotetext{
${ }^{23}$ Speaking generally once again, it is also true that, in the case of a multi period and extended site, erosion and ploughing affect the archaeological deposit but, at the same time, expose archaeological remains through the removal of vegetation and the disturbance of buried strata, periodically bringing new sherds to the surface.
} 
terrace and the low northern slope, within the 20x20 m squares used for the geomagnetic investigations, we laid out smaller regular units, sixteen for each square, measuring $5 \times 5 \mathrm{~m}$. In a different way, we decided to divide the six radial sectors (lots 1-4, -1, -2) on the E-SE slope into five, four and three bands, irregular shaped ${ }^{24}$ (like segments of a circumference, concentric with respect to the curve of the main mound and lower terrace) in order to fit the collecting grid to the morphology of the slope. In this case we considered as limits of the single unit the main changes in level and agricultural field boundaries. The entire intensively surveyed area where intensive collection was carried out totalled 3 ha ca equalling roughly more then $30 \%$ of the site coverage.

The team consisted of seven operators on average during the 2008 campaign (six fieldwalkers and one member at the total station), and five operators in the 2009 campaign. Shovels and rods were used to clean the soil of residual vegetation not removed with the rakes. During 2008 campaign the fieldwalkers took nine days to cover the entire area arranged for the collection; seven days during the 2009 campaign. Even so, as the low visibility fields could not be avoided, we attempted to compensate for this bias, reducing the dimension of the area to be surveyed by one person. As regard the campaign of 2008, the average of units surveyed each day was 24.90 on the terrace (4.14 units per person) and 4.44 on the slope ( 0.70 units per person); in 2009,73 ca units on the terrace (14.6 ca per person) and 1 on the slope ( 0.2 per person). Over the course of the first season each fieldwalker attained an average rate of coverage on the terrace of approximately $100 \mathrm{~m}^{2}$ per day as compared to $360 \mathrm{~m}^{2}$ in 2009 , due to a better surface visibility. ${ }^{25}$

In each of surveyed units we picked up all the artefacts from the surface. ${ }^{26}$ Diagnostic artefacts, that is to say artefacts giving information as regard chronology and function of the assemblage, all fragments and lithics, were systematically collected for each surveyed field unit as well as fragments of roof tiles and baked-bricks. During the campaign of 2008 the diagnostic artefacts were marked and mapped. ${ }^{27}$

\section{SAMPLES ANALYSIS (V. Orsi)}

In the course of the two campaigns carried out in 2008 and 2009, a total of approximately $824 \mathrm{Kg}$ of samples were recovered within the surveyed area. The corpus consists mostly of potsherds (17880 potsherds for a total weight of ca. $590 \mathrm{Kg}$ ), but also a notable quantity of roof tiles (200 Kg ca) and a few slags (34 Kg ca) were collected (Tab. 1).

\footnotetext{
24 The dimensions of these units (each lot is divided in different bands, coinciding with different collecting units) vary from $5 \times 30$ to $30 \times 50 \mathrm{~m}$. The first band of units, near the edge of the terrace, is narrower; the dimensions increase as we move towards the valley floor. The particular form of sectors -1 and -2 is due to the curvature of the foot of the high mound.

${ }^{25}$ The difference of coverage is also due to the fact that during the second part of the 2008 survey more time was dedicated exclusively to the collection of sherds rather than other activities, such as the arrangement of the topographical grid and geomagnetic investigations that took up part of the crew in the first days. During the 2009 campaign more time was dedicated to weighing, counting and recording pottery sherds.

${ }^{26}$ The collection units were given individual names with the use of numbers and letters (20x20 m square labelled with letters and main units of the slope labelled as lots 1-6; 5x5 m square and single small units of the slope labelled with numbers).

${ }^{27}$ In the square $\mathrm{J} 19$ we mapped all the artefacts to assess the feasibility of a very intensive collecting approach.
} 
The density of roof tiles, of which both flat (tegulae) and half tub tiles (imbrices) have been found, clearly indicate some form of occupation on the site in 'late' periods (Late Roman/Byzantine), mainly concentrated on the lower terrace (fig. 14). Both flat tiles with squared profile flanges (cut across the top edges) and rounded profile flanges have been found. Finger grooves next to the flanges and incised lines are usually visible on the upper surface of tiles, whereas imprints of chaff and reed ragged lines are recurrent characteristics of the lower surface. Roof tiles are distributed all over the eastern, northern and western sectors of the terrace, but they seem to be particularly concentrated in a few squares of the N-NE sector, mainly in proximity of the terrace border. Among these, a definitely significant concentration is registered in the square F13. As concerns the terrace slopes, roof tiles seem to be homogeneously dispersed all over the south-eastern lots 1 to 4, while they seem to be virtually absent within the southern lots 1 to -2 . Even though the presence of Roman or Byzantine structures cannot be excluded, the dispersed distribution pattern on the S-SE slope of the terrace might have resulted from erosion and ploughing, while both 'cappuccina' burials or structures might have been located on the terrace.

The sample of slags includes different variants of melted combustion residuals. The nature of the primary artefacts is not clearly recognisable but a clay material origin is in most cases quite likely. Among these, the remains of burnt bricks and wall elements, identified by the presence of reed impressions on the surface, have been recovered on the SE terrace and on the $\mathrm{S}$ terrace slope, and might be evidence of destruction by fire (fig. 14). A valuable concentration of melted residuals from combustion, slag and ceramic waste which in theory might have been related to kiln activities, are concentrated in squares K19, J19 and I19, near the north-eastern slope of the höyük. On the contrary, the distribution within the other sectors of the terrace seems to be mainly scattered. The concentration within the same area of both slags and irregular geomagnetic anomalies could reflect an interconnected phenomenon.

In respect of slags, roof-tiles seem to be widespread over a great part of the terrace. The distribution of both series of samples, probably as a result of modern activities on the soil, may be considered principally homogeneous for most of the surveyed area. However, sectors of major concentration emerge for both samples, but in an essentially diverging area. The two sets of samples could therefore pertain to a non-interrelated order of phenomena, and thus possibly reflect a different chronological phase of occupation on the site.

As concerns pottery, a total number of 17,880 potsherds have been collected. Among these, potsherds valuable in chronological terms, that is inclusive of rim, base, decoration, spout or handle, have been sorted into the diagnostic category $(3,335$ potsherds); the remaining poorly preserved potsherds have been sorted into the generic category $(14,545)$. The ceramic samples are widespread all over the surveyed area, but the distribution does not seem perfectly homogeneous (see tab. 1 and fig. 14). In the majority of cases, that is 27 units, the total amount of pottery recovered for survey units is between 5 and $10 \mathrm{Kg}$, followed by amounts between 10 and $15 \mathrm{Kg}$ (19 survey units), and then less than $5 \mathrm{Kg}$ (14 survey units). Only in a few areas did the quantity of sherds amount to more than $15 \mathrm{Kg}$ (6 survey units). A major concentration is registered in the squares at the base of the Höyük (H15), on the S-SE upper slopes of the terrace (band 3 of lots 2 and 3) 
and on the NE slope of the terrace (F20), where, according to the geomagnetic survey results, a conspicuous structure seems to be located.

A general classification based on wide-ranging parameters such as fabric typology and wall thickness, has been established to distinguish, as far as possible, common from storage and kitchen wares. A different distribution might reflect a potential macroscopic differentiation in the destination of the surveyed areas. The main ceramic class attested is the Common Ware, of which a total amount of $465 \mathrm{Kg}$ ca has been registered, but a few examples of Storage (119 Kg ca.) and a small percentage of Kitchen wares (5 Kg ca.) have been also recovered.

The distribution pattern of Common Ware testifies to a quite sensible differentiation of the surveyed areas (fig. 15). In comparison with the eastern and northern part of the lower terrace, the concentration on the western part seems to be definitely inferior (see squares L5; L6), while a conspicuous amount of pottery is recorded in the proximity of the base of the höyük (squares H13-H15) and on the upper slopes of the terrace (band 2 and 3 in lots 2, 3 and 4; squares F20), mainly in connection with erosion phenomena. The concentration within the lots -1 and -2 is however inferior to than in lots 2, 3 and 4 .

The distribution of Storage Ware (fig. 15) is evidence of a certain differentiation: in a few cases, a greater concentration of storage ware corresponds to a greater concentration of pottery (like in lot 2-band 3 or square F20), but in other cases the concentration seems to be independently high - as in the first band of lot 2 and in the third band of lot 4, on the terrace southern slope, and in square F17, on the northern part of the terrace - or particularly reduced - as in squares G17-19, H14, H16-18 and D9.

The Kitchen Ware (fig. 15 and tab. 1) is attested in small percentages only, but its distribution does not seem related to the main distribution units of pottery. A certain concentration seems in fact to be located within the southern lots -1 and -2 .

As regards ceramic technology, with a very few exceptions, sherds seem to be all wheel-thrown.

Plain Ware constitutes the major component of the assemblage of Uşakli/Kuşakl Höyük. Finishing usually consists of simple smoothing, but 'self-slips' resulting from wet-smoothing are also well attested. The colours of the clay vary mainly between brown and orange nuances: brown and reddish brown colours seem to be the most widespread, but buff nuances are also attested. Within the Plain Ware sample, standardized 'drab' ware, with uniform grit tempered fabric, can be easily recognized. The scraping marks made by trimming off the excess clay after its removal from the wheel are clearly visible on the surface.

A quite significant component of the Uşaklı/Kuşaklı Höyük ceramic inventory is represented by different varieties of slipped or burnished wares. The most conspicuous is certainly the red-slipped ware. Several variants are, however, attested with regards to manufacture, finishing techniques and colours, indicating different traditions. The colour of the slip ranges from light red/pinkish red or reddish orange to purple red, reddish brown or reddish violet. The slip could be thick and homogeneously applied, probably by dipping, or very thin and unevenly applied, possibly by being wiped onto the surface of the vessel with a cloth or an instrument. The surface can be lustrous or mat. The slip is 
usually limited to the outer surface of the vessel or to its sole upper part, covering often a small portion of the inner rim. Among the variants are attested fine tempered sherds with thick light-red/orange slip and deep smoothed surface, purple red/reddish brown and lustrous slip specimens, pinkish wiped slip sherds with chaff fabric, red edged vessels and red-slipped storage jars.

Other types to be mentioned are the orange-slipped sherds, both in fine or rough fabrics; brown ware sherds, with a well-smoothed or slightly burnished surface, common and rough fabrics with yellow or whitish slip and some fine ware sherds with shining micaceous slip, probably to be identified with the Gold Wash Ware.

Painted Ware is documented by different types: common wares with simple red paint traces; bi-chrome painted ware in red and black colours; black painted ware and polychrome painted ware with white background and red and black colours. Furthermore, the hand-made painted ware, characterised by chaff and grits tempers and burnished surface, constitutes a distinct type.

\section{PreliminARY REMARKS On the CERAMiC ASSEMblage (A. D’Agostino)}

Notwithstanding all the above-mentioned elements which result in massive biases in the survey data, a good representative sample of ceramics has been collected. The site in fact is characterised by relatively medium density and spatially extensive scatters. The systematic collection yielded a sufficient amount of pottery to identify the ware and shape groups and, accordingly, to date the occupation of the site and suggest the nature of the settlement during different periods. Dating surface pottery is, however, a challenge, particularly in areas where there is no continuous stratified sequence nearby which has been excavated or, as is the case with the central Anatolian plateau, we do not yet know enough about the different assemblages, as U.-D. Schoop (2009: 146) noted, due to the marked homogeneity that characterised most of the ceramic production over a long period of time. Thus, typological continuity and the slow development of types from the karum period onwards limit our ability to date survey assemblages.

Comparisons from Uşakl1/Kuşaklı Höyük sherds and those recovered from excavated contexts showing similar characteristics, such as fabric and surface treatments, constitute the basic method used to date our material. A considerable proportion of the sherds collected can only be dated to very broad periods, or overlaps two or more periods. For the moment we are able to present the ceramics according to very general chronological ranges.

We have assembled a sample of fragments that we believe to be representative of different types found on the terrace. Only a small selection of the repertoire is presented here: the bulk of the sherds will be published in the final report of the Uşakl1/Kuşaklı Höyük survey. The pottery from the survey will be presented according to general chronological phases that we have been able to distinguish.

Up until now, no traces of material dated to the first periods of the Early Bronze Age have been found. The only traces of earlier occupation of the site are a few hand- 
made and 'Cappadocian' painted sherds (fig. 18: 1-11), dating to the transition from the Early Bronze Age to the Middle Bronze Age.

The distribution of red-slipped sherds is homogeneous and covers wide sectors of the terrace. In some cases the similarities in shape and manufacturing allow us to establish some comparisons with ceramic types dating with a good degree of reliability to more restricted periods.

Carinated red slipped bowls, often with vertical V-shaped handles (fig. 18: 11-17), are generally good markers of the karum (Schoop 2009: 151; Schirmer 1969: pl. 24-25) and Old-Hittite period (Mielke 2006: 149, 123). ${ }^{28}$ The hole-mouth with half-moon shaped lugs (fig. 18: 18) could be pertinent to the late Early Bronze Age as well as to the Early Iron Age horizons.

The carinated bowls with short vertical (fig. 18: 21-22) or long incurved upper sides (fig. 19: 19-20), usually red slipped on the outer edge or completely slipped, find comparisons in Kuşaklı Höyük/Sarissa (Mielke 2006: pl. 57.44, 58.1, 56.5) and Kinet Höyük (Gates 2006: 305-306), for example. Some types of jars in red slipped ware (fig. 18: 24-29) could be dated to the Late Bronze Age, having comparisons in Kuşakl1 Höyük/Sarissa; a similar typology of vessels and rims are documented also during the karum period and in the Iron Age. Some spouts (fig. 19: 40-42), vertical handles (fig. 19: 45-48) belonging to jars and special vessels have to be dated to the same span of time (Mielke 2006: 147, abb.142), although some examples could be earlier or later. Spouted jar like n. 30 and beak spouts with tip curved downwards usually occur during the karum period: the fragments n. 30, 38 and 47 have a good red polished glossy surface. Six fragments of body sherds (fig. 19: 31-36; fig. 25) and one handle (n. 37) with stamp impressions on them are documented from the karum to the Hittite periods (Seidl 1972: A50-52). Among these we have two sherds (n. 31-32) bearing partial impressions of the 'signe royal' (for comparisons see Seidl 1972: A33, 36 and A26; Boehmer and Güterbock 1987: pl. XLII, 328). Five of these sherds with stamp impressions were recovered on the eastern slope of the terrace.

Curved bowls, shallow bowls with thickened rim and curved bowls with in-turned upper side (fig. 21) represent typical findings distributed on the terrace. All these types, with similar tempers and surface treatment, constitute our 'drab' repertoire.

As regards the bowls in 'drab ware', generally buff to brown in colour, comparison with published assemblages establishes a close similarity with ceramic wares and shapes of the Hittite repertoire. Plain small and medium sized bowls with simple and often pointed rims (fig. 20: 49-52), bowls with thickened rims (fig. 20: 54-59), large flat bowls with thickened rim (fig. 20: 60) and large plates (fig. 20: 61-68) are recurrent types in our Late Bronze Age assemblage. It seems that these types have to be dated to the Hittite period, on the basis of the Böğazköy sequence (Parzinger and Sanz 1992: pl. 26.19-27, 38.1-6; Schoop 2003: 173; 2006: 215-239) and building C of Kuşaklı Höyük (Mielke

\footnotetext{
${ }^{28}$ Some specimens continue to be used up until the end of Late Bronze Age, at Kaman-Kalehöyük for example (Matsumura 2005: 305.KL96-M51).
} 
2006: 128-134; pl. 57, 55). Generally it is assumed that the coarse cooking plates (fig. 20: 63-68) are more frequent between the Middle Hittite period and the first part of Empire period. The string impression around the rim attested in several cases is an element the diffusion of which in Böğazköy reached its peak around the middle of $15^{\text {th }}$ century (Schoop 2003: 231-233).

The distribution of carinated medium-large sized bowls with inturned upper wall in plain ware, brown in colour (fig. 21: 80-83), is unclear, but concentrated in a specific area in association with typical 'drab ware' sherds: some comparisons have been found with the layers of Kaman-Kalehöyük dating to the end of the Hittite empire period (Matsumura 2005: pl. 7:KL94-M72) or within level V of Porsuk (Dupré 1983: pl. 19, figs. 113-116), but the association between this type of carinated bowls and drab specimens could be fortuitous.

Our hole-mouth cooking pots (fig. 21: 74-77) usually have a globular body and folded rim. This shape also fits well with the examples dating to the Late Bronze Age contexts.

Sherds of funnel-necked jars, and necked craters, red slipped or in plain ware, could be pertinent both to the Late Bronze and Iron Age horizons (fig. 20: 27-29; fig. 21: 69-73). Some necked jars in common (fig. 21: 71-73) or red slipped ware (fig. 21: 69-70) and craters with black painted motifs (fig. 22: 90-96) are typical of this period and find comparisons, for instance, with Phrygian levels of Böğazköy (Bossert 2000: Farbtafel E: 272, 291; pl. 6, 9, 11, 15, 18, 22, 117-120, 123, 133), Alişar Höyük (von der Osten 1937: fig. 445-471) and Kaman-Kalehöyük (Matsumura 2005: pl. 134.KL-P63abc/P90;88-1023).

Storage jars and pithoi (fig. 25), in common and red slipped wares, cannot be dated with certainty exclusively on the base of the morphology. In some cases, the use of both red slip and white/buff slip on the rim or below it (fig. 24: 133-134), offers comparisons with specimens documented at Kuşaklı Höyük/Sarissa and Böğazköy (Mielke 2006: 142; Müller-Karpe 1988: 146, pl. 48).

Iron Age period sherds show no specific concentration in any area, which may be the result of modern agricultural disturbances and erosion. Near the base of the slopes of the high mound, and on different points of the terrace, we found painted sherds with black colour (Alişar IV type) (fig. 22) dating to the Middle/Late Iron Age. Also documented are painted sherds with a white background and red and black colours (polychrome ware) (fig. 22: 101) and probably an example of bichrome ware decorated with a band and concentric circles (fig. 22: 99). No hand-made Early Iron Age sherds have been found during the survey. Rim sherds, often ledged, of craters and open mouthed closed vessels, occurring in a wide range of sizes and forms, are typical of Iron Age, from Early to Late Phrygian, levels and find comparisons in Gordion (Sams 1994: figs. 34-55) and Böğazköy (Bossert 2000: pl. 5-26). The repertoire of painted bowls, jars, craters and handles finds good comparisons in Böğazköy Phrygian levels (Bossert 2000: pl. 63-67, 75) and other sites of the central plateau where a Middle/Late occupation has been documented.

Several groups of sherds presenting recurrent characteristics in terms of morphology and technology are probably to be dated to the 'later' periods, given the lack of comparanda with the repertoire excavated in other sites of central Anatolia dating to $2^{\text {nd }} / 1^{\text {st }}$ millennium. However, it should be noted that the remarks offered here are to be considered 
as preliminary proposals open to future modification when an in-depth study of the collected samples from the site is conducted and provides more substantial information.

Considering the preliminary stage of our study on the pottery repertoire, it is more problematic to date a group of sherds belonging to small necked jars characterised by a thin wall (fig. 23: 119-123) and some bowls in plain ware with ribbed rim (fig. 23: 113114) or thickened grooved rim (fig. 23: 115-116). All these types, together with some types of handles (fig. 23: 125-132), likely belonging to Late Roman/Byzantine amphoras and middle sized jars, share similar characteristics in their manufacturing, whilst the morphology and technology indicate a move away from the types that we have preliminarily dated to the Middle/Late Bronze Age and to the first part of the Iron Age. Preliminarily, we could try some general dates: red-orange slipped table-wares (fig. 23: 105-106) could be specimens or imitations of later Eastern red slipped ware; fine bowls (fig. 23: 110-112) could preliminary be dated to the Late Iron Age/Hellenistic periods; ribbed rim bowls find comparisons in level III of Porsuk (Dupré 1983: fig. 76, 108-109) but a later date cannot be excluded. Some of the shiny and well-smoothed slipped wares (whitish and pale yellow, red, orange) might well belong to this late period whereas some doubts arise regarding two small thin bowls (fig. 23: 107-109) that probably could be considered a fine production dating to the Middle/Late Bronze Age (Dupré 1983: 29 and pl. 5, figs. 11-13) or Iron Age.

These sherds documenting a late occupation dating from late Iron Age onwards till the more recent Late Roman/Byzantine periods are scattered mainly on the western portion of the terrace, although a fair number have also been noted in the northern sector. Roof tiles, representing sporadic traces of the late occupation in the Roman/Byzantine period, are similar to specimens found for example at Amorium, in the Afyon region (Witte-Orr 2007: 295-308): tiles both with cut flanges and others with rounded upper edged flanges document occupations at the sites probably around $5^{\text {th }}$ and $8^{\text {th }}$ centuries AD the Late Byzantine period. Finger groove decorations and footmarks are also documented on the upper surface of some tiles.

The presence of a fragmentary ring base in Glazed Ware with blue floral decoration on a white background, probably dating to the Seljukid/Medieval (?) period, is amongst the more recent artefacts found at the site.

\section{REMARKS ON POTTERY DISTRIBUTION (A. D’Agostino, V. Orsi)}

Some sectors of the site show traces of heavier occupation in certain periods. In fact the assemblage collected during a survey is not a random sample but is generally dominated by material that lay on or close to the original land surface. ${ }^{29}$

According to the distribution of diagnostic sherds, the $2^{\text {nd }}$ millennium appears to be concentrated mostly on the low slopes of the terrace.

\footnotetext{
${ }^{29}$ For issues concerning depositional processes and post-depositional problems see Taylor 2000: 16-26.
} 
It is often difficult to draw a clear distinction among the different phases of $2^{\text {nd }}$ and $1^{\text {st }}$ millennium and, at the moment, we are not able to assert if our red slip ware sherds belong to the Middle/Late Bronze Age horizon instead of the Iron Age. We can only highlight that the majority of the diagnostic sherds seem to have good parallels with types found at Middle Bronze Age/Late Bronze Age sites. In many cases, however, this does not exclude the possibility that they may instead pertain to the Iron Age horizon. We have some types that we can hardly consider chronological markers of a century as they are represented in $2^{\text {nd }}$ millennium assemblages of all periods. This difficulty is related mainly to the sherds with red slip and some types of vessels which continued to be in use until the Late Bronze Age.

The correspondence of $2^{\text {nd }}$ millennium sherds and some buried structures identified by the geomagnetic survey can hardly be considered fortuitous. In particular, the density of Drab Ware diagnostic sherds (fig. 16) over a limited area of the northern and eastern slopes (collecting units F19-20 and lot 2, bands 2, 4; lot 3, bands 2-3), may suggest, as a preliminary consideration, that architectural remains appearing beneath the surface might belong to the Late Bronze Age period. A noteworthy density of Drab Ware sherds has been found at the foot of high mound. Red slipped ware were found fairly evenly across the entire mound with a major density on the south-eastern slopes of the terrace (lots 1-4), where a fair number of diagnostic sherds, such as bowls with triangular handles (fig. 15) and sherds with impressed stamps, probably dating to the karum period, are also mainly distributed.

Hand-made sherds, probably to be dated to the transitional period between the Early and the Middle Bronze Age, have been found mainly on the terrace with a noteworthy concentration at the foot of the high mound and at the base of the northern terrace slope (fig. 17). Instead the later sherds are homogeneously dispersed over the terrace.

The first season of surveying provided us with the first pieces of systematic information about the occupational history of the mound. Subsequent analysis of the ceramics suggest the site was mainly occupied from the end of the Early Bronze Age to the Byzantine period, with an intensive occupation during the $2^{\text {nd }}$ millennium. ${ }^{30}$ The majority of diagnostic sherds collected during the first two seasons of work can be assigned to this period. A discrete number of sherds dated to the later periods (Middle Iron Age-Byzantine period) was also acquired mainly on the top of the terrace and in proximity of the high mound slope, while only a handful of sherds (end of Early Bronze Age) document the earlier occupation of the site. To date we do not know whether there was a break in the occupational sequence of the site.

\footnotetext{
${ }^{30}$ A simple walk around the lower city suggests that the extent of the $2^{\text {nd }}$ millennium settlement covered all the terrace and its slopes.
} 


\section{THE CLAY BULLA UK09.OB.1 (S. Mazzoni)}

The clay bulla was found on the northern outer slope of the terrace (fig. 5) in the course of a systematic collection of materials in grids coordinated with the geo-magnetic survey that indicated the presence of quite a large building. The sealing ${ }^{31}$ (fig. 26) consists of two impressions set at 90 degrees on a lump of clay; only one (a) has preserved the complete drawing of the original seal, while the second (b) shows only a small sector preserved. The readable impression (a) was made by a circular stamp with a slightly ridged and grooved base. The field is framed by an arc of a guilloche and an arc of spirals. In the middle there is a motif which is partially eroded and not deeply impressed. We can, however, identify on the top left a stylised head (?) facing left whereas the right part of the drawing is more damaged and only traces of the design can be cautiously recognised as a head (?) facing right. They are connected in the middle to a horizontal line over a vertical spiral-like motif. I would tentatively suggest a doubleheaded eagle with spiralled body and open wings, but the quite different rendering of the motif on the top right could indicate a different animal's head (lion?). Other interpretations cannot be ruled out, such as a stylised animal head or a hieroglyphic sign. The presence of the girdle constituted half by a guilloche and half by a spiral design does allow quite precise comparisons with old Hittite stamps; for example, there is a quite similar stamp seal from Hattuša dated by R.M. Boehmer to the $2^{\text {nd }}$ half of the $17^{\text {th }}$ cent. with a frieze composed of a spiral with three volutes and a guilloche (Boehmer 1987, 43, 45, no. 105, Pl. X). ${ }^{32}$ A bulla from the Palace of Level I of Konya Karahöyük (Alp 1968, 38, 181-182, no. 70, fig. 82, p. 38, P1. 74/195, from Area L, Level I, Room 6 [Inv. Nr.55/253]; Boehmer 1987, Fig. 23a) presents two frames both made with a girdle composed of half spirals and guilloches; in the middle there is an eagle with two heads, spread wings and the body rendered by a spiral. The vertical spiral motif of our bulla fits better with this spiral rendering. Different motifs and symbols are usually drawn in the centre of these stamps (altars, hands, heads of different animals, hieroglyphs) which may often be rendered in a rather crude and schematic manner and cannot be identified easily. The seals of this group are attributed to the Old Hittite period, around the $17^{\text {th }}-16^{\text {th }}$ cent. B.C.; a date in the second half of the $17^{\text {th }}$ cent. has been proposed for the Hattuša seal and can also be proposed for the Karahöyük bulla on the basis of its find context. ${ }^{33}$

\footnotetext{
${ }^{31}$ The colour of the sealed area is Munsell 7.5YR5/1; the colour of the clay is Munsell 2.5YR3/2.

${ }^{32}$ See comparisons: 43, Figs. 23, 28. Seals showing friezes with a more complex design with an entwined spiral can also be dated to the $16^{\text {th }}$ cent.

${ }^{33}$ In the Level I palace two old Syrian style cylinder seals were also found (central room: 117-119, no. 7, Inv. Nr. 55/56, pls. 11/23; Room 1: 26-27, 131-132, no. 36, Pl. 46/110) and a Syro-Hittite seal (sealings found in rooms 3 and 7: 25, $122-123$, no. 15 , Inv. $55 / 189$, Pls. $39 / 96,40 / 97-98$ ); they also suggest a $17^{\text {th }}$ cent. B.C. date.
} 


\section{The HitTite TABLet UK09.OB.2: A PRELIMINARY ANALYSIS (C. Corti)}

On September 3, 2009, during the routine collection of materials on the surface of the southern area at the base of the Uşaklı/Kuşaklı Höyük mound (fig. 5), Valentina Orsi found a fragment of a Hittite cuneiform tablet (fig. 27).

The piece is extremely burned - to the point that several parts are in an advanced state of vitrification - probably due to a violent fire; the overheating was so strong that it literally liquefied the clay on part of the left edge that, consequentially, melted along the anterior face, covering the beginning of the lines. ${ }^{34}$

The tablet measures $7.9 \mathrm{~cm} \mathrm{~h}$. x $8.3 \mathrm{~cm} \mathrm{w}$., and the maximum thickness is $4.3 \mathrm{~cm}$. Two faces are partially preserved. The colour of the obverse is light reddish brown (Munsell 2.5YR 7/4); the reverse is light gray (2.5Y 7/2); the edge and the initial part of the obverse are weak red (2.5YR 5/2).

The fragment, which has been preliminarily labelled with inventory number UK09.Ob.2, presents writing on both sides. The distinction between the obverse and the reverse is proposed based on the different form of the faces since this is not definable from the context: the obverse has a surface that tends towards flat, the reverse is convex.

Since the left edge narrows in the upper part of the fragment, the obverse must belong to the first half of the tablet and, consequently, the reverse to the lower half, even though it is not possible to quantify the distance from the end. Additionally, given the thickness of the inner part, it is held that originally the tablet was made up of at least two columns on each side.

The obverse of the tablet is composed of 13 lines and, approximately, from two to five signs of the beginning are missing (due to the melted clay); on the reverse, the start of 14 lines is preserved. ${ }^{35}$

Concerning the typology of the document, it could be a magical ritual (see the mention of the "tongue" in obv. 2', the "soul" in the rev. 4'-5' and of the "clay statue" in rev. 10') but, at the moment, we cannot confirm this suggestion with any certainty, the tablet being very fragmentary.

The "Sun god of the Heaven" is cited two times (obv. 3', 5') and the word "Earth" is cited several times (obv. 6', 12', rev. 6'-7') in the document; we can also find two personal names (female in rev. 8' and male rev. 9'), partially in lacuna.

In a preliminary way, we can date the fragment between the $14^{\text {th }}$ and the $13^{\text {th }}$ cent. B.C., that is, in the Hittite chronology, the Imperial period. ${ }^{36}$

\footnotetext{
${ }^{34}$ During the 2008 and 2009 campaigns, numerous bricks and slags were found in the area that had undergone the same transformation processes as those observed for the tablet.

${ }^{35}$ In the last line, the beginning of two extremely damaged cuneiform signs can be made out.

${ }^{36}$ The complete edition of the text will be published by the mission's team of philologists, composed, in addition to the writer, of Prof. Franca Pecchioli Daddi (University of Florence) and Dr. Giulia Torri (University of Florence); associated with this group is Prof. Alfonso Archi (University of Rome, La Sapienza).
} 
The tablet was found in the section of the southern slope in correspondence with the point in which the terrace of the "lower town" finishes and joins the mound of the "upper town". I believe it is possible that the fragment slid into such a low zone of the mound due first to a "runoff" effect and then due to subsequent agricultural activity. In my opinion it could come from the south-eastern area of the upper mound; this hypothesis would find correspondence in the synthetic description of the discovery site of the tablet that I recently published in KBo 52 with number $280^{37}$ and which was definitely found at Uşakl1/Kuşaklı Höyük (Summers, Summers, Ahmet 1995: 55): “Ostabhang des Hoyuks ostl. von Taşl1k", according to the information reported by Otten, on indications of Cornelius. $^{38}$

It can be added that, in various points of the same zone, there are clear traces of remains of burnt mudbrick structures. Therefore, in my opinion, the archive could be located in that area and the two tablets have effectively come from there. Obviously, this is merely a working hypothesis that could only be confirmed by systematic excavations.

\section{CONCLUSIOns (S. Mazzoni)}

The materials collected in the survey of Uşaklı/Kuşaklı Höyük and its adjacent area give evidence of a continuous occupation of this sector of the plain from the $2^{\text {nd }}$ millennium $\mathrm{BC}$ to the medieval period. The floruit of the occupation was most probably reached during the Late Roman and Byzantine period. The site has provided materials, pottery and tiles over all the lower town or low terrace extension and its outskirts. Scatters of materials (tiles and pottery) were also found in the hills to the south of the site and in the adjacent valleys and hillocks. Large well-dressed blocks are scattered over the gentle hills limiting the site to the south. These stones, a few of them probably reused by older Uşakl1/Kuşaklı Höyük buildings of the Hittite phase, can be attributed to a possibly not too ephemeral farmstead. The occupation of the Late Roman period might have been connected to the intensification of land exploitation and agriculture to obtain mainly crops, barley and wheat, a process which is well documented in other regions of the central Anatolian plateau for the same period.

In the Iron Age the area was apparently little settled; no mounds or scatters of materials belong clearly to this phase. Uşakl1/Kuşaklı Höyük Höyük produced sparse and not abundant materials belonging to the later Iron Age and the Phrygian period which were collected near the base of the central mound but also in the outer fields and might have come from the central mound itself. However, although it would appear quite logical

\footnotetext{
${ }^{37}$ Corti 2009: Inhaltsverzeichnis XII Nr. 280 (comment and bibliography), 51 (autography). Information on the discovery of this fragment can be found in Cornelius 1964: 12.

${ }^{38}$ For the history of the exploration of the site and for the edition of KBo 52.280, see C. Corti, "The History of the Exploration of Uşakl1/Kuşaklı Höyük (Yozgat) and the 'Rediscovery' of a Middle Hittite Tablet”, in preparation. The manuscript of $\mathrm{H}$. Otten, with the transcription «in the field» and the relative note on the discovery site are conserved at the Akademie der Wissenschaften und der Literatur, Mainz.
} 
the Phrygian settlement on the central mound, we cannot de facto exclude the possibility that it extended over a wider area including part of the terrace or lower town.

The second floruit phase of the site was reached in the Hittite period, in the course of the entire $2^{\text {nd }}$ millennium B.C. During this period the site already covered more than 10 ha. The fact that most of the Old Hittite and even earlier materials, such as Cappadocian and red slipped Kültepe wares, were found on the outskirts of the terrace can substantiate the hypothesis of a large settlement consisting of a lower town and an acropolis already during this older phase. This is however the extension that the site had in the Hittite imperial period, as documented by the surface materials. The geo-magnetic and resistivity survey provides evidence of large buildings on the terrace and its adjacent edges; their plans and regular walls, their size and the division into different units of rooms can be better compared with ceremonial and institutional buildings of the Late Hittite period. The fact that a curtain of casemate walls and possibly a gate can be seen on the eastern side of the outer terrace and that structures of a certain complexity and size can be seen beyond the edge of the terrace indicates that the town's outer limits were well beyond the edge of the outer terrace. The terrace thus seems to be constituted by the settlement of both the Imperial Hittite and the Old Hittite phases covered by an apparently not high deposit belonging mainly to the Roman period. Instead, no materials of the Old Hittite or Imperial periods have yet been collected in the territory, a fact which seems to indicate that, in the course of the $2^{\text {nd }}$ millennium B.C., occupation might have been concentrated only in the town of Uşakl1/Kuşaklı Höyük while in the surrounding land it might have been of a rather ephemeral and sparse nature, not easily detected by the survey.

\section{BIBLIOGRAPHY}

Atalan Çayırezmez, N., P. Ertepınar Kaymakçı, and G.D. Summers, 2008 - Remote Sensing at Kerkenes: Combining Geophysical and Other Methods, Yerbilimleri 29, no. 2, pp. 87-100.

Alp, S., 1968 - Zylinder- und Stempelsiegel aus Karahöyük bei Konya, Türk Tarih Kurumu Basımevi 26, Ankara.

Boehmer, R.M., 1987 - Althethitische Zeit, in: Boehmer and Güterbock 1987: 33-56.

Boehmer, R.M., 1987 - Gestampelte Keramik, in: Boehmer and Güterbock 1987: 117-118.

Boehmer, R.M., and H.G. Güterbock, 1987 - Glyptik aus dem Stadtgebiet von Boğazköy. Grabungskampagne 1931-1939, 1952-1978 (Boğazköy-Hattuša: Ergebnisse der Ausgrabungen XIV), Gebr. Mann, Berlin. 
Bohlendorf-Arslan, B., A.O. Uysal and J. Witte-Orr (eds.), 2007 - Late antique and Medieval pottery and tiles in Mediterranean archaeological contexts: Proceedings of the First International Symposium on Late Antique, Byzantine, Seljuk, and Ottoman pottery and tiles in archaeological contexts (Çanakkale, 1-3 June 2005) (=BYZAS 7, Veröffentlichungen des Deutschen Archäologischen Instituts Istanbul), Ege Yayınları, Istanbul.

Bossert, E.-M., 2000 - Die Keramik phrygischer Zeit von Boğazköy: Funde aus den Grabungskampagne 1906, 1907, 1911, 1921, 1931-1939 und 1952-196 (Boğazköy-Hattuša: Ergebnisse der Ausgrabungen XVIII), Verlag Philipp von Zabern, Mainz am Rhein.

Branting, S., 1996 - The Alişar Regional Survey 1993-1994: A Preliminary Report, Anatolica 22: 145-158.

Campana, S., and R. Francovich (eds) 2006 - Laser scanner e GPS, All'Insegna del Giglio, Firenze.

Campana, S., and S. Piro (eds.), 2009 - Seeing the Unseen, Taylor and Francis Group, London, pp. 79-80.

Cornelius, F., 1964 - Zur hethitischen Landeskunde. Ergebnisse der 2. W. Esch-Expedition 1962, Bibliotheca Orientalis 21, pp. 11-15.

Corti, C., 2009 - Texte aus dem Bezirk des Großen Tempels IV (Keilschrifttexte aus Boghazköy 52), Berlin.

Corti, C., in prep. - The History of the Exploration of Uşakl1/Kuşaklı Höyük (Yozgat) and the 'Rediscovery' of a Middle Hittite Tablet.

Erler, A., and M.C. Göncüoğlu, 1996 - Geologic and tectonic setting of the Yozgat batholith, Northern Central Anatolian Crystalline Complex, Turkey, International Geology Review, vol. 38, pp. 714-726.

Fales, M.F., St. de Martino, S. Ponchia, K. Strobel, 2009 - Austro-Italian Archaeological Investigations in the Region of Yozgat /Turkey), in: Pecchioli Daddi et al. 2009, pp. 31-37.

Fischer, B., H. Genz, É. Jean and K. Köroğlu, (eds.) - Identifying Changes: the Transition from Bronze to Iron Ages in Anatolia and its Neighbouring Regions, Proceedings of the International Workshop Istanbul, November 8-9, 2002, Türk Eskiçağ Bilimleri Enstitüsü, Istanbul.

Francovich, R., H. Patterson and G. Barker, (eds.), 2000 - Extracting meaning from ploughsoil assemblages (The Archaeology of Mediterranean Landscapes 5), Oxbow Books, Alden press, Oxford.

Forrer, E., 1927 - Ergebnisse einer archäologischen Reise in Kleinasien, 1926, Mitteilungen der Deutschen Orient-Gesellschaft 65, pp. 31-37.

Gates, M.-H., 2006 - Dating the Hittite Levels at Kinet Höyük: a Revised Chronology, in: D.P. Mielke, U.-D. Schoop, J. Seeher, eds., Strukturierung und Datierung in der hethitischen Archäologie (=BYZAS 4, Veröffentlichungen des Deutschen Archäologischen Instituts Istanbul), Ege Yayınları, Istanbul, pp. 293-309.

Gorny, R.L., 1994 - The 1993 Season at Alişar Höyük in Central Turkey, Anatolica 20: 191-202.

Gorny, R.L., 1995 - The Alişar Regional Project 1994, Anatolica 21: 65-100.

Gurney, O.R., 1995 - The Hittite Names of Kerkenes Dağ and Kuşaklı Höyük, Anatolian Studies XLV, 69-71.

Keay, S., M. Millett, J. Robinson, J. Taylor, N. Terrenato 2000 - Falerii Novi: a new survey of the walled area, Rome, vol. 68, pp. 1-94.

Koşay, H.Z., 1966 - Ausgrabungen von Alaca Höyük: Vorbericht über die Forschungen und Entdeckungen von 1940-1948, Türk Tarih Kurumu Yayınlarından, V. seri - Sa. 6, Türk Tarih Kurumu Basımevi, Ankara.

Matsumura, K., 2005 - Die Eisenzeitliche Keramik in Zentralanatolien aufgrund der Grundlage der Ausgrabung von Kaman-Kalehöyük (PhD Diss. Freie Universität Berlin).

Meriggi, P., 1971 - Ottavo e ultimo viaggio anatolico, Oriens Antiquus 10: 57-60.

Mielke, D.P., 2004 - Die Ausgrabung des Nordwest-Tores, in: Müller-Karpe et al. 2004, Untersuchungen in Kuşakl1 2003, Mitteilungen der Deutschen Orient-Gesellschaft 136: 137-172 .

Mielke, D.P., 2006 - Die Keramik vom Westhang (Kuşakl1-Sarissa, band 2), Verlag Marie Leidorf GmbH, Rahden/Westfalen.

Mielke, D.P., U.-D. Schoop, J. Seeher (eds.), 2006 - Strukturierung und Datierung in der hethitischen Archäologie (=BYZAS 4, Veröffentlichungen des Deutschen Archäologischen Instituts Istanbul), Ege Yayınları, Istanbul. 
Müller-Karpe, A., 1988 - Hethitische Töpferei der Oberstadt von Hattuša: ein Beitrag zur Kenntnis spätgrossreichszeitlicher Keramik und Töpferbetriebe unter Zugrundelegung der Grabungsergebnisse von 197882 in Boğazköy (Marburger Studien zur Vor- und Frühgeschichte, 10), Hitzeroth Verlag, Marburg/Lahn.

Müller-Karpe, A., mit beiträgen von V. Müller-Karpe, D.P. Mielke, A. Schachner, H. Stümpel, E. Jean und R. Pasternak 1998 - Untersuchungen in Kuşaklı 1997, Mitteilungen der Deutschen Orient-Gesellschaft 130: 93-174.

Müller-Karpe, A., mit beiträgen von V. Müller-Karpe, A. Schachner, T.A. Ökse, J. Miller, S. Lorra, H. Stümpel und R. Pasternak 1999 - Untersuchungen in Kuşaklı 1998, Mitteilungen der Deutschen Orient-Gesellschaft 131: 57-113 .

Özgüç, T., 1982 - Maşat Höyük II: A Hittite center northeast of Boğazköy, Türk Tarih Kurumu Yayınlarından, V. dizi - Sa.38, Türk Tarih Kurumu Basımevi, Ankara.

Parzinger, H., and R. Sanz, 1992 - Die Oberstadt von Hattuša: hethitische Keramik aus dem zentralen Tempelviertel. Funde aus den Ausgrabungen 1982-1987 (Boğazköy-Hattuša: Ergebnisse der Ausgrabungen XV), Gebr. Mann Verlag, Berlin.

Pecchioli Daddi, F., G. Torri and C. Corti (eds.) 2009 - Central-North Anatolia in the Hittite Period. New Perspectives in Light of Recent Researches (Acts of the International Conference held at the University of Florence, 7-9 February 2007) (Studia Asiana 5), Herder, Roma.

Sams, G.K., 1994 - The Early Phrygian Pottery (The Gordion Excavations, 1950-1973: Final Reports Volume IV, University Museum Monograph 79), University of Pennsylvania, Philadelphia.

Schachner, A., 1998 - Grabungen am Südost-Tor, in: Müller-Karpe et al. 1998: 93-174.

Schachner, A., 1999 - Grabungen am Südost-Tor, in: Müller-Karpe et al. 1999: 57-113.

Schmidt, A., 2009 - Electrical and magnetic methods in archaeological prospection, in: Campana and Piro 2009: 79-80.

Schoop, U.-D., 2003 - Pottery Tradition of the Late Hittite Empire: Problems of Definition, in: Fisher et al. 2003: $215-238$

Schoop, U.-D., 2006 - Dating the Hittites with Statistics: Ten Pottery Assemblages from BoğazköyHattuša, in: Mielke et al. 2006: 215-239.

Schoop, U.-D., 2009 - Indications of Structural Change in the Hittite Pottery Inventory at BoğazköyHattuša, in: Pecchioli Daddi et al. 2009: 145-167.

Seidl, U., 1972 - Gefässmarken von Boğazköy (Boğazköy-Hattuša: Ergebnisse der Ausgrabungen VIII), Gebr. Mann Verlag, Berlin.

Strobel, K., and Chr. Gerber, 2007a - Das internationale Tavium Projekt. Bericht über die Kampagne 2005, 25. Araştırma Sonuçları Toplantısı, CILT.2, Ankara: 15-34.

Strobel, K., and Chr. Gerber, 2007b - TAVIUM (Büyüknefes, Provinz Yozgat) - Bericht über die Kampagnen 2003-2005, Istanbuler Mitteilungen 57: 547-621.

Summers, M.E.F., G.D. Summers and K. Ahmet, 1995 - The Regional Survey at Kerkenes Dağ: an Interim Report on the Seasons of 1993 and 1994, Anatolian Studies 45: 43-68.

Summers, G.D., and M.E.F. Summers, 2006 - Aspects of Urban Design at the Iron Age City on the Kerkenes Dag as Revealed by Geophysical Survey, Anatolia Antiqua 15: 71-88.

Taylor, J., 2000 - Cultural depositional processes and post-depositional problems, in: Francovich et al. 2000: 16-26.

von der Osten, H.H., 1929 - Explorations in Hittite Asia Minor 1927-1928 (Oriental Institute Publications VI), University of Chicago Press, Chicago.

von der Osten, H.H., 1937 - The Alishar Höyük: Seasons of 1930-32, Part II (Oriental Institute Publications XXIX), University of Chicago Press, Chicago.

Witte-Orr, J., 2007 - Bricks and Tiles from the Triangular Tower at Amorium, in: Bohlendorf-Arslan et al. 2007: 295-308. 
TABLE 1. ARTEFACTS RECOVERED IN 2008/2009 (NUMBERS AND WEIGHT)

* Preliminary labelling of Survey Units as in 2008 (Mazzoni et alii in 31.Kazı Sonuçları Toplantısı 2009)

** Samples cumulative number for Survey Units; *** Samples cumulative weight (in kg) for Survey Units

\begin{tabular}{|c|c|c|c|c|c|c|c|c|c|c|c|}
\hline 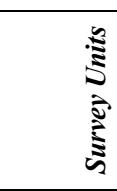 & 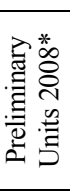 & 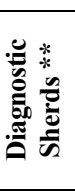 & 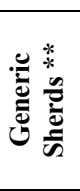 & 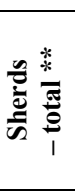 & 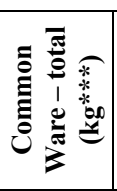 & 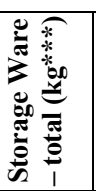 & 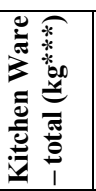 & 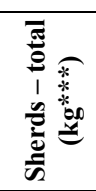 & 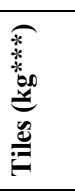 & 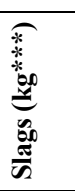 & 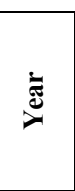 \\
\hline D9 & & 29 & 267 & 296 & 7,255 & 0,78 & 0,104 & 8,139 & 0,15 & 0,06 & 2009 \\
\hline D10 & & 11 & 198 & 209 & 5,76 & 1,6 & 0,016 & 7,376 & 5,98 & 0,1 & 2009 \\
\hline D14 & & 27 & 177 & 204 & 6,09 & 1,5 & 0,46 & 8,05 & 2,28 & 0,02 & 2009 \\
\hline$D 15$ & & 21 & 252 & 273 & 6,48 & 3,94 & 0,245 & 10,67 & 0,65 & 0,35 & 2009 \\
\hline E16 & & 30 & 298 & 328 & 9,3 & 3,98 & 0,02 & 13,3 & 8,51 & 2,73 & 2009 \\
\hline F13 & & 28 & 275 & 303 & 7,88 & 2,15 & 0,498 & 10,53 & 28,44 & 0,34 & 2009 \\
\hline$F 14$ & & 25 & 298 & 323 & 7,37 & 1,92 & 0,29 & 9,58 & 13,52 & 0,14 & 2009 \\
\hline F15 & & 20 & 306 & 326 & 7,28 & 3,04 & 0,04 & 10,36 & 6,67 & 0,01 & 2009 \\
\hline F16 & & 39 & 220 & 259 & 7,16 & 2,66 & 0,04 & 9,86 & 17,52 & 0,15 & 2009 \\
\hline F17 & & 36 & 217 & 253 & 6,555 & 8,88 & & 15,44 & 16,5 & & 2009 \\
\hline F18 & & 23 & 216 & 239 & 5,895 & 1,4 & & 7,295 & 1,78 & 0,36 & 2009 \\
\hline G13 & & 34 & 315 & 349 & 8,835 & 1,68 & 0,22 & 10,74 & 5,46 & & 2009 \\
\hline G14 & & 50 & 304 & 354 & 7,55 & 1,38 & & 8,93 & 0,84 & 0,11 & 2009 \\
\hline G15 & & 70 & 375 & 445 & 11,56 & 1,61 & 0,2 & 13,37 & 1,3 & 0,21 & 2009 \\
\hline G16 & & 44 & 380 & 424 & 9,96 & 1,37 & & 11,33 & 1,29 & 0,11 & 2009 \\
\hline G17 & & 62 & 305 & 367 & 7,4 & 0,49 & & 7,89 & 3,3 & 0,1 & 2009 \\
\hline G18 & & 44 & 220 & 264 & 6,49 & 0,91 & 0,02 & 7,42 & 2,68 & 0,52 & 2009 \\
\hline$H 13$ & & 75 & 330 & 405 & 12,89 & 1,3 & & 14,19 & 0,48 & & 2009 \\
\hline H14 & & 64 & 549 & 613 & 13,06 & 0,88 & 0,015 & 13,96 & 1,04 & & 2009 \\
\hline H15 & & 104 & 585 & 689 & 19,94 & 2,45 & 0,04 & 22,43 & 0,3 & & 2009 \\
\hline H16 & & 77 & 334 & 411 & 6,76 & 0,54 & & 7,3 & 0,2 & 0,045 & 2009 \\
\hline H17 & & 44 & 279 & 323 & 6,76 & 0,89 & 0,04 & 7,69 & & 0,135 & 2009 \\
\hline H18 & & 60 & 271 & 331 & 6,775 & 0,46 & & 7,235 & 11,48 & 1,46 & 2009 \\
\hline L10 & & 11 & 198 & 209 & 6,81 & & 0,24 & 7,05 & 2,88 & 0,013 & 2009 \\
\hline L11 & & 32 & 313 & 345 & 8,265 & 0,4 & 0,12 & 8,785 & & 0,31 & 2009 \\
\hline L5 & & 8 & 109 & 117 & 2,96 & 0,68 & 0,045 & 3,685 & 6,01 & 0,4 & 2009 \\
\hline L6 & & 3 & 128 & 131 & 2,355 & 0,16 & 0,035 & 2,55 & 4,1 & 0,01 & 2009 \\
\hline$L 7$ & & 10 & 153 & 163 & 4,05 & 1,75 & 0,04 & 5,84 & 7,04 & 0,08 & 2009 \\
\hline$L 8$ & & 23 & 162 & 185 & 5,47 & 0,88 & 0,015 & 6,365 & 1,57 & & 2009 \\
\hline L9 & & 32 & 265 & 297 & 8,11 & 4,08 & 0,41 & 12,6 & 1,73 & & 2009 \\
\hline$M 11$ & & 25 & 291 & 316 & 7,34 & 1,25 & 0,045 & 8,635 & 0,32 & & 2009 \\
\hline$N 11$ & & 16 & 173 & 189 & 4,868 & 0,3 & 0,13 & 5,298 & 0,03 & 0,04 & 2009 \\
\hline$K 19$ & A & 65 & 155 & 220 & 6,31 & & 0,18 & 6,49 & 0,30 & 6,82 & 2008 \\
\hline$J 19$ & B & 227 & & 227 & 4,83 & 2,10 & 0,04 & 6,97 & 2,90 & 3,95 & 2008 \\
\hline 119 & $\mathrm{C}$ & 103 & 358 & 461 & 6,16 & 1,80 & & 7,96 & 1,13 & 6,40 & 2008 \\
\hline H19 & D & 67 & 276 & 343 & 7,29 & 1,77 & & 9,06 & 12,01 & 2,06 & 2008 \\
\hline G19 & E & 82 & 324 & 406 & 12,03 & 0,20 & & 12,23 & 15,56 & 2,82 & 2008 \\
\hline F19 & $\mathrm{F}$ & 96 & 341 & 437 & 10,47 & 1,67 & & 12,14 & 0,86 & 0,18 & 2008 \\
\hline$F 20$ & G & 137 & 396 & 533 & 16,54 & 3,42 & 0,23 & 20,19 & 0,98 & 0,13 & 2008 \\
\hline
\end{tabular}




\begin{tabular}{|c|c|c|c|c|c|c|c|c|c|c|c|}
\hline 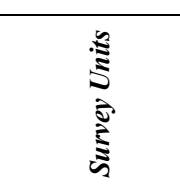 & 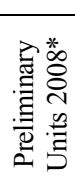 & 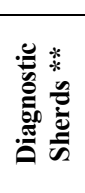 & 苞 & 窇 & 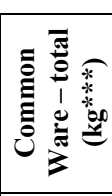 & 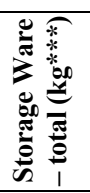 & 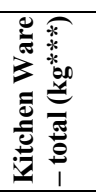 & 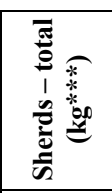 & 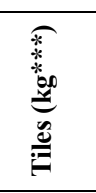 & 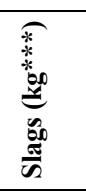 & $\ddot{\nexists}$ \\
\hline Lot -1 ; band 2 & & 7 & 92 & 99 & 2,35 & & 0,025 & 2,375 & & 0,3 & 2009 \\
\hline Lot $-1 ;$ band 3 & & 7 & 89 & 96 & 2,98 & 0,3 & 0,05 & 3,33 & & 0,8 & 2009 \\
\hline Lot $-1 ;$ band 4 & & 18 & 168 & 186 & 4,88 & & 0,13 & 5,01 & 1,05 & & 2009 \\
\hline Lot-1; band 5 & & 16 & 102 & 118 & 3,56 & 0,38 & 0,06 & 4 & & 0,01 & 2009 \\
\hline Lot $-2 ;$ band 3 & & 5 & 32 & 37 & 1,21 & & 0,02 & 1,23 & & 0,4 & 2009 \\
\hline Lot $-2 ;$ band 4 & & 8 & 69 & 77 & 3,08 & & 0,3 & 3,38 & & 0,02 & 2009 \\
\hline Lot $-2 ;$ band 5 & & 8 & 78 & 86 & 2,545 & 0,14 & 0,01 & 2,695 & & & 2009 \\
\hline Lot 1 ; band 1 & 113 & 21 & 59 & 80 & 2,22 & 1 & & 3,22 & 0,2 & & 2008 \\
\hline Lot 1 ; band 2 & 114 & 39 & 71 & 110 & 4,7 & 2 & & 6,7 & 2,1 & & 2008 \\
\hline Lot 1 ; band 3 & 115 & 43 & 129 & 172 & 5,6 & 3,6 & & 9,2 & 0,5 & & 2008 \\
\hline Lot 1 ; band 4 & 116 & 26 & 63 & 89 & 3 & 1,3 & & 4,3 & 1,85 & 1,5 & 2008 \\
\hline Lot 1 ; band 5 & 117 & 34 & 71 & 105 & 2,85 & 2,3 & & 5,15 & 0,85 & 0,32 & 2008 \\
\hline Lot 2 ; band 1 & 118 & 38 & 63 & 101 & 2,94 & 11,05 & & 13,99 & 0,5 & & 2008 \\
\hline Lot 2; band 2 & 119 & 90 & 267 & 357 & 11,58 & 3 & & 14,58 & & & 2008 \\
\hline Lot 2; band 3 & 120 & 157 & 498 & 655 & 16,43 & 5,6 & & 22,03 & & & 2008 \\
\hline Lot 2; band 4 & 121 & 116 & 201 & 317 & 8,4 & 1,78 & & 10,18 & 0,206 & & 2008 \\
\hline Lot 2; band 5 & 122 & 89 & 231 & 320 & 8,7 & 1,33 & & 10,03 & 0,24 & & 2008 \\
\hline Lot 3; band 1 & 123 & 29 & 66 & 95 & 2,22 & 1,9 & & 4,12 & 1,4 & 0,2 & 2008 \\
\hline Lot 3 ; band 2 & 124 & 74 & 293 & 367 & 9,51 & 2,7 & 0,17 & 12,38 & 0,62 & 0,18 & 2008 \\
\hline Lot 3 ; band 3 & 125 & 153 & 284 & 437 & 15,80 & 2,8 & & 18,6 & 0,3 & & 2008 \\
\hline Lot 3; band 4 & 126 & 91 & 203 & 294 & 8,44 & 1,6 & 0,13 & 10,17 & 0,36 & & 2008 \\
\hline Lot 3 ; band 5 & 127 & 29 & 66 & 95 & 2,96 & 0,42 & & 3,38 & 0,2 & & 2008 \\
\hline Lot 4; band 1 & 128 & 4 & 13 & 17 & 0,62 & & & 0,62 & & & 2008 \\
\hline Lot 4; band 2 & 129 & 104 & 229 & 333 & 11,54 & 2,12 & 0,2 & 13,86 & 0,74 & 0,18 & 2008 \\
\hline Lot 4; band 3 & 130 & 75 & 346 & 421 & 10,74 & 6,64 & 0,08 & 17,46 & 0,88 & & 2008 \\
\hline Lot 4; band 4 & 131 & 62 & 80 & 142 & 4,38 & 0,82 & 0,01 & 5,21 & 0,22 & & 2008 \\
\hline Lot 4; band 5 & 132 & 29 & 69 & 98 & 3,47 & 0,31 & & 3,78 & 0,5 & & 2008 \\
\hline Outside Unit & & 9 & & 9 & & & & & & & 2009 \\
\hline TOT & & 3335 & 14545 & 17880 & 465,6 & 119,4 & 4,963 & 589,9 & 200,5 & 34,07 & $\begin{array}{r}2008 / \\
2009\end{array}$ \\
\hline
\end{tabular}




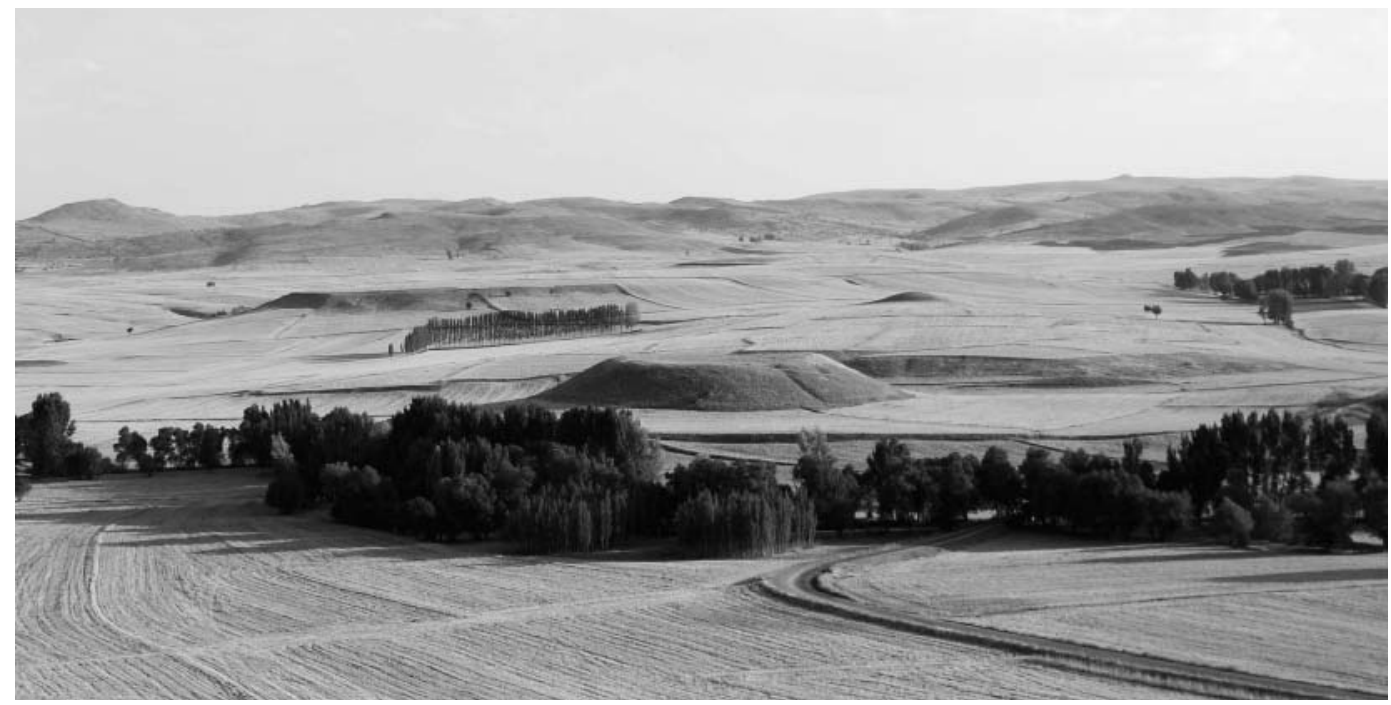

Fig. 1. View of Uşakl1/Kuşaklı Höyük, from north.

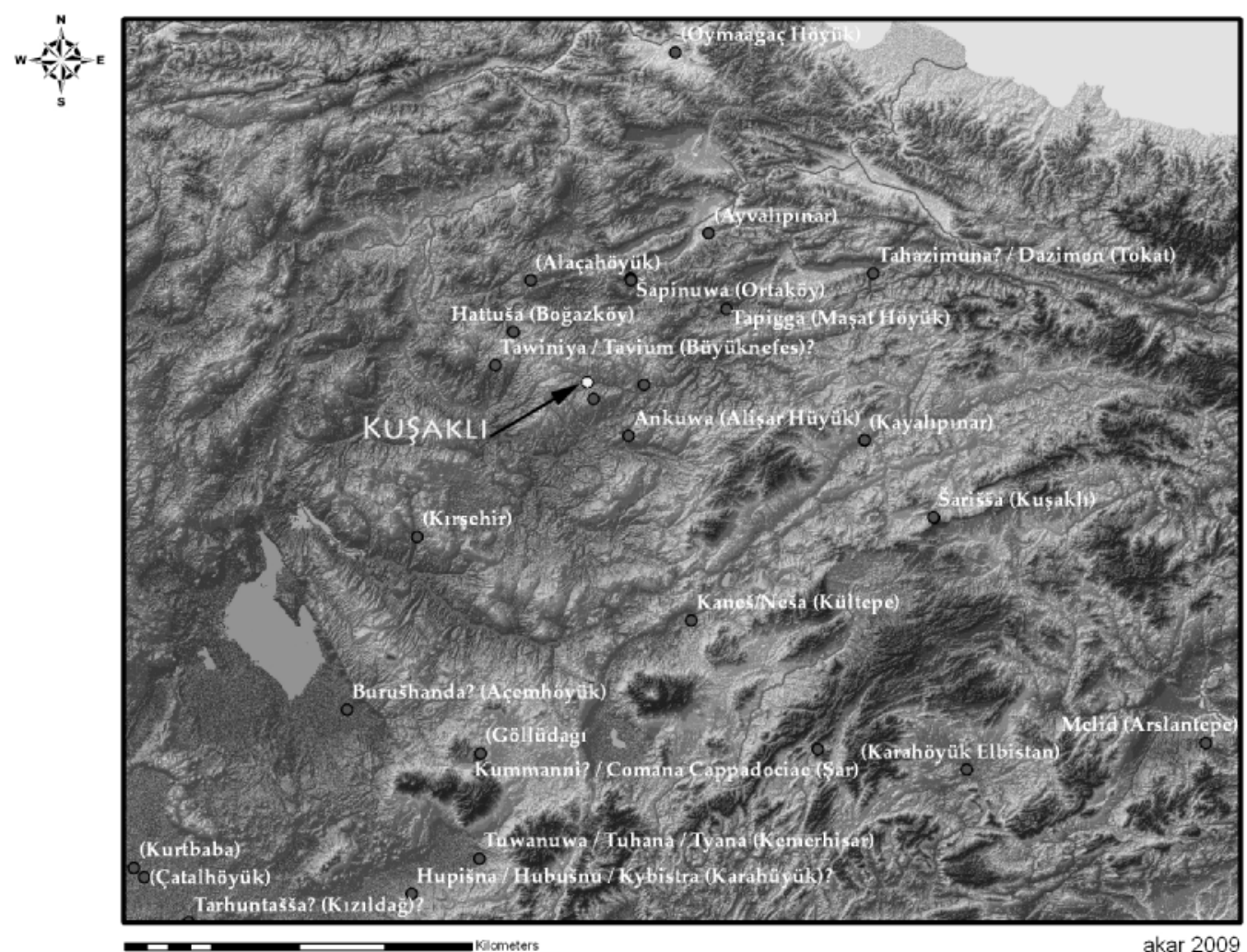

Fig. 2. Maps of Central Anatolian Plateau showing the location of Uşaklı/Kuşaklı Höyük and other sites (by M. Akar). 


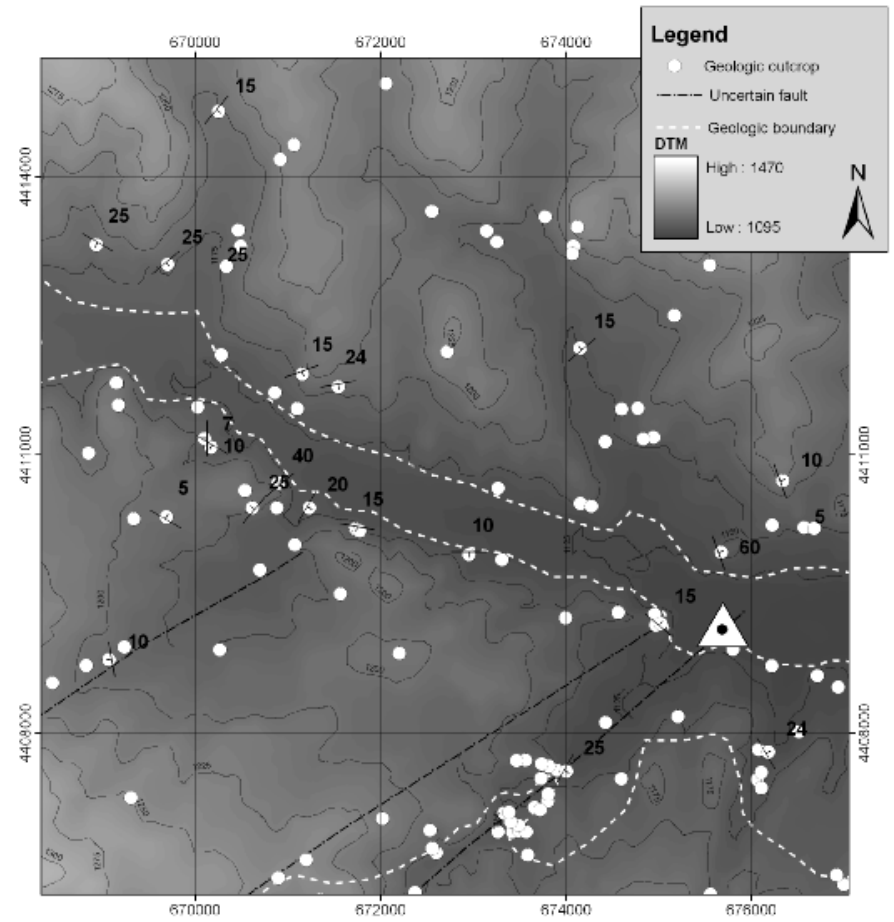

Fig. 3. Sketch map of geologic outcrops, boundaries and faults displayed over the Digital Terrain Model (DTM) (by R. Salvini).

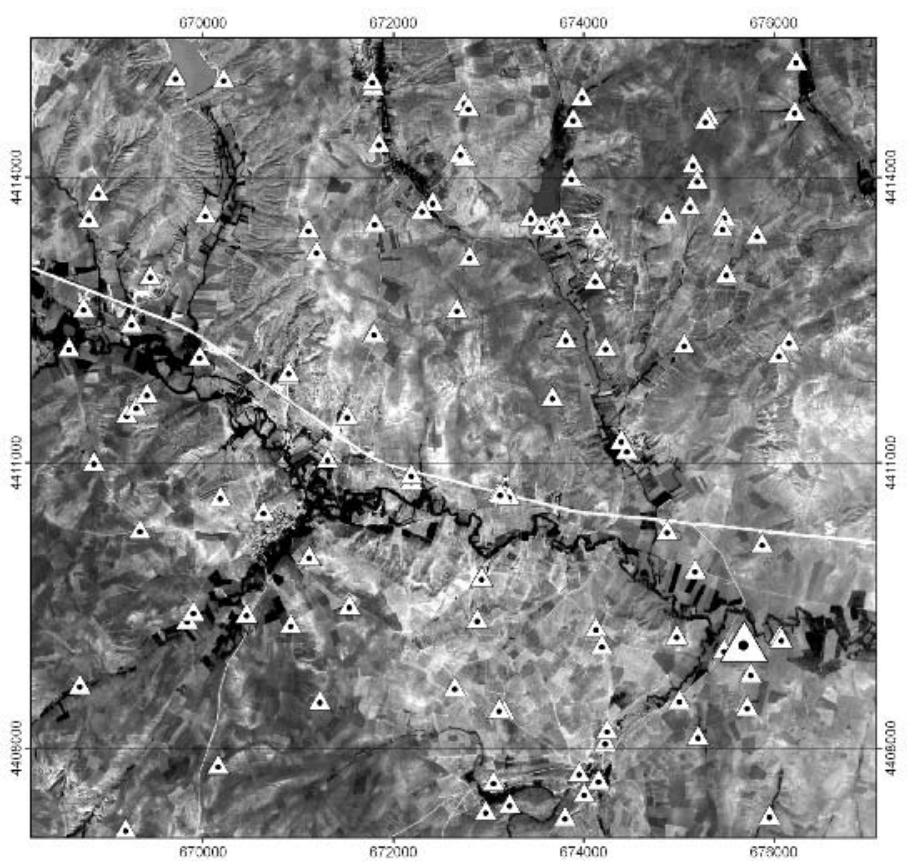

Fig. 4. Spatial distribution of GCPs shown over the GeoEye image (by R. Salvini). 


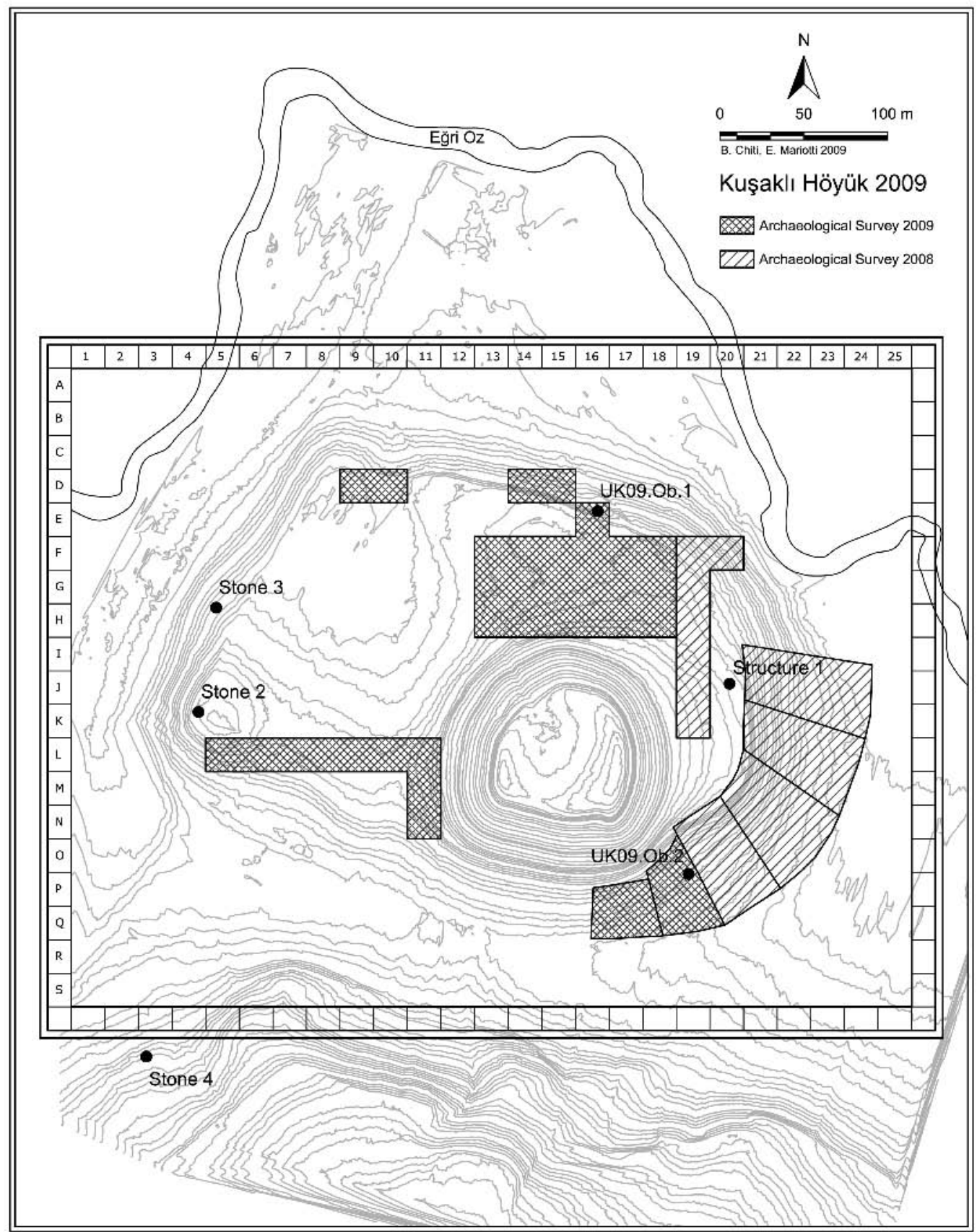

Fig. 5. Topographic map of Uşaklı/Kuşaklı Höyük with archaeological survey areas and location of architectural remains and objects found on the surface (by B. Chiti and E. Mariotti). 


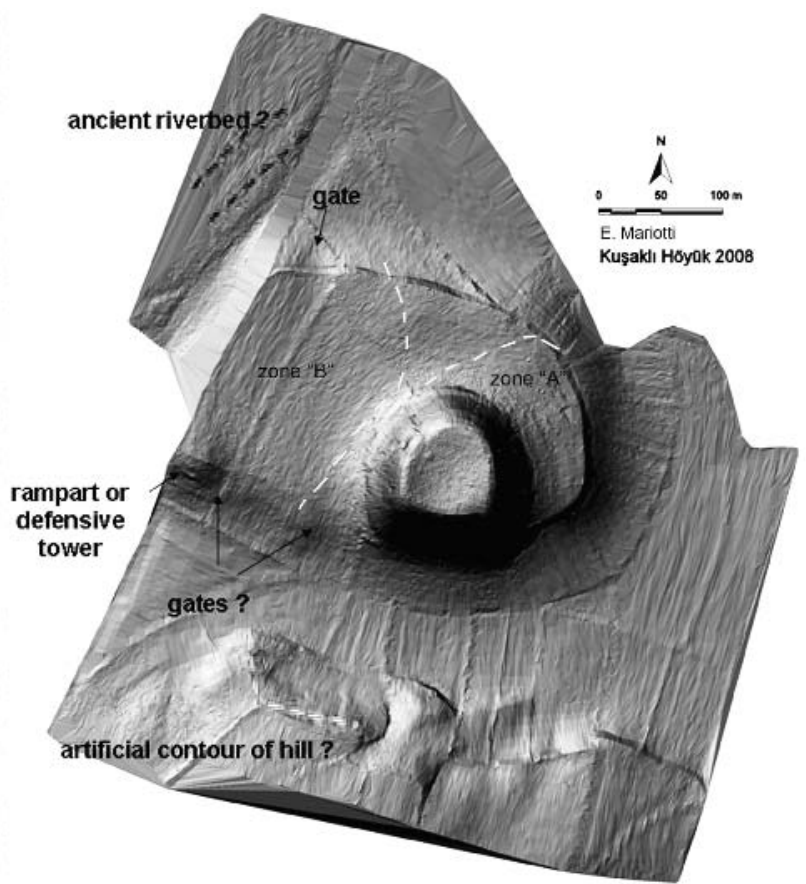

Fig. 6. Three-dimensional model of Uşakl1/Kuşaklı Höyük (by E. Mariotti).

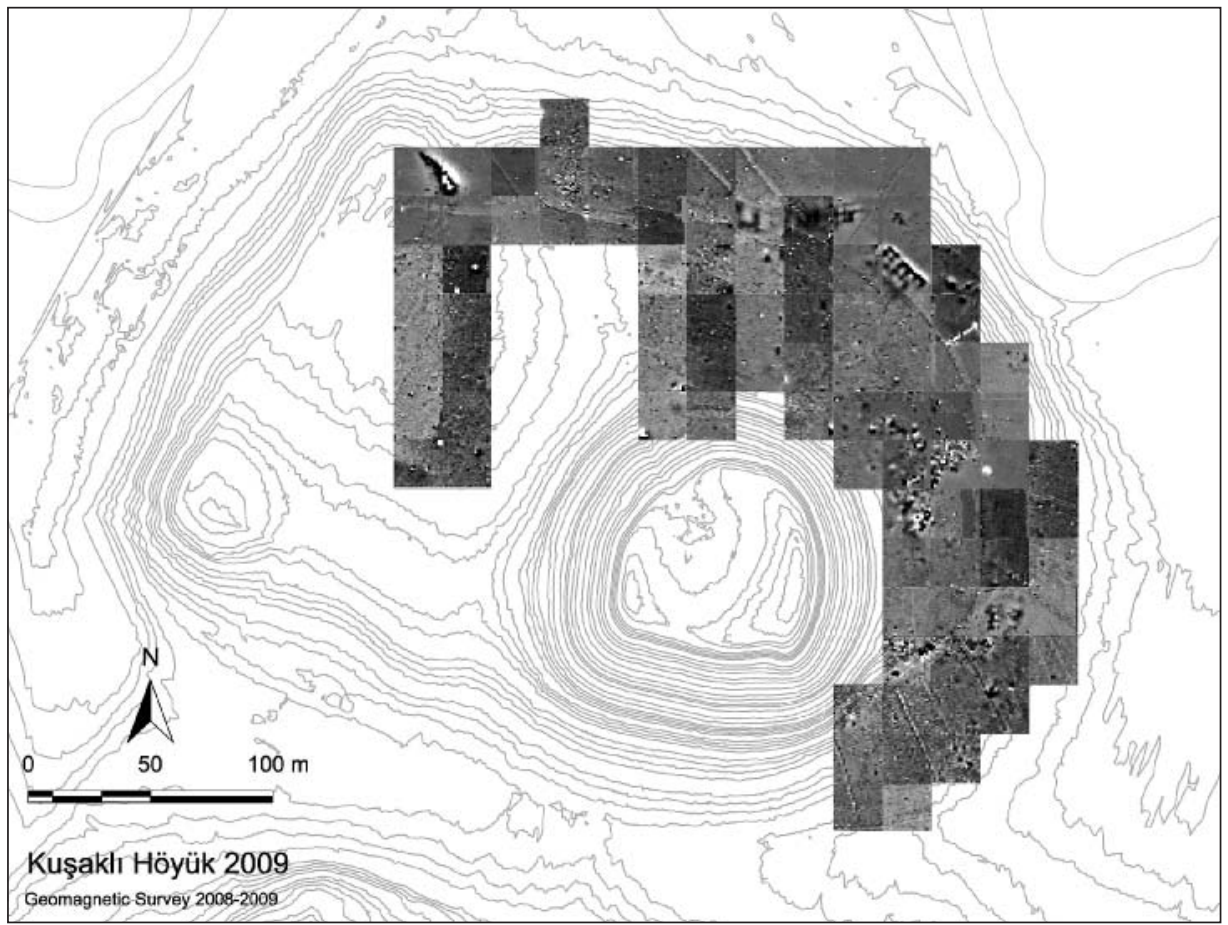

Fig. 7. The 2008 and 2009 magnetic survey (by G. Carpentiero). 


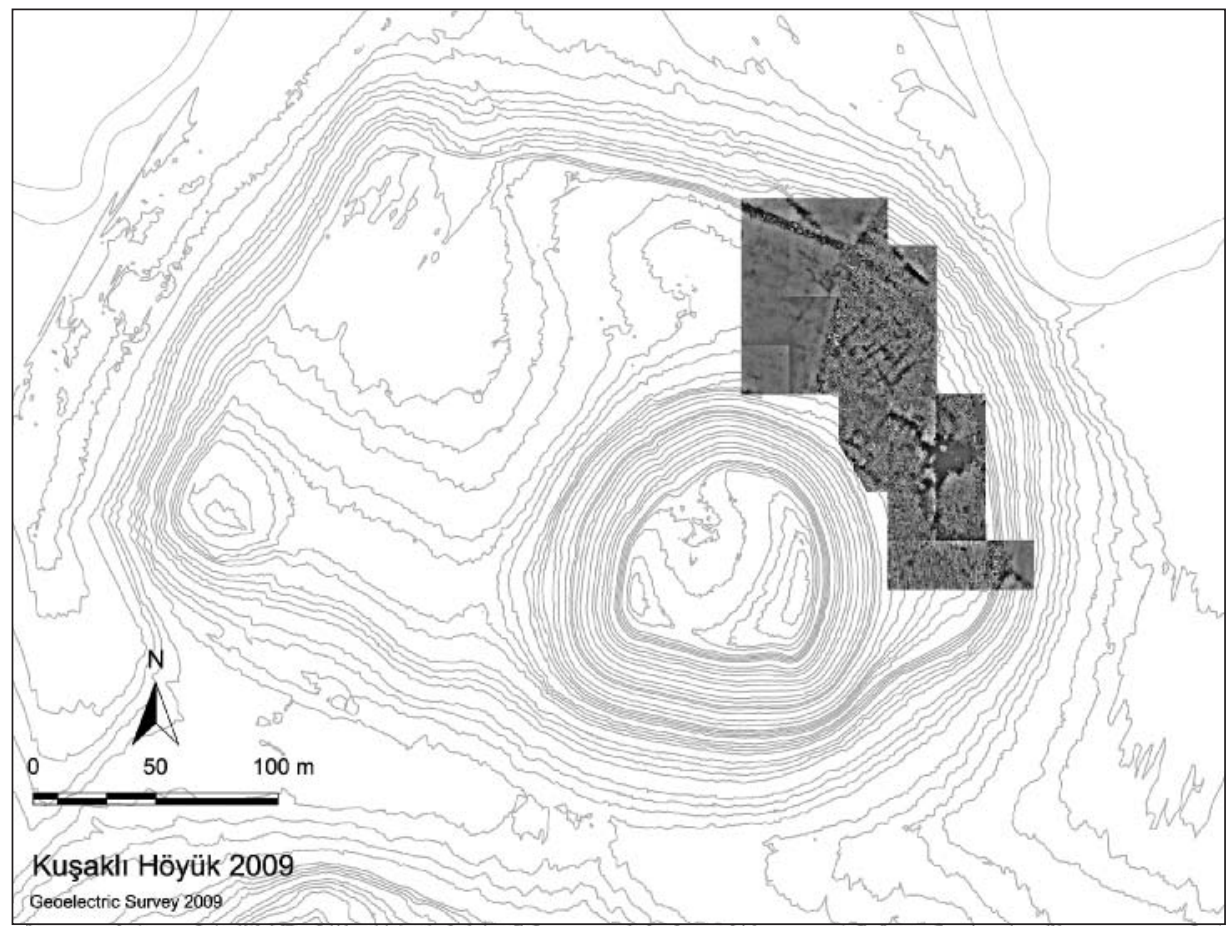

Fig. 8. The 2009 geoelectric survey (by G. Carpentiero).

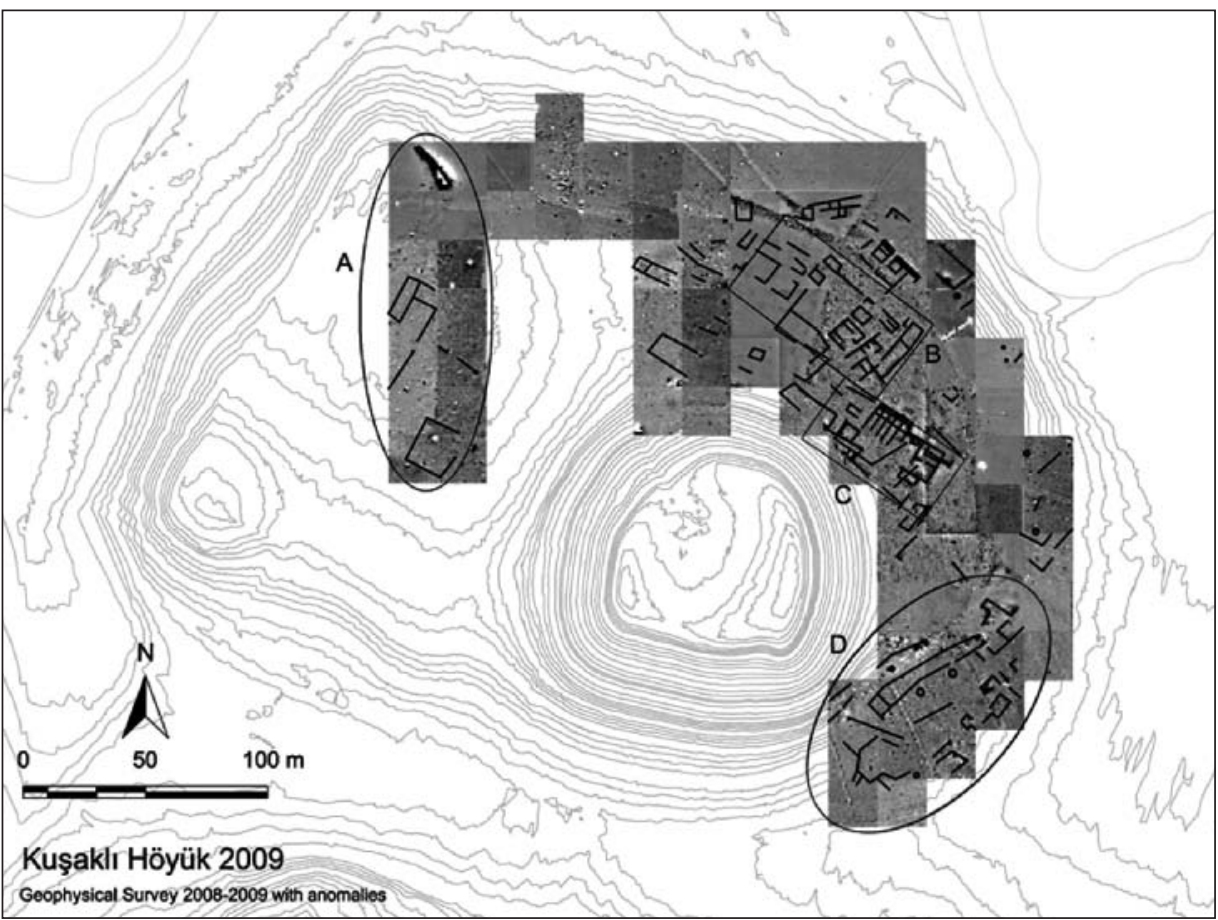

Fig. 9. Interpretation of geophysical surveys with main areas identified (by G. Carpentiero). 


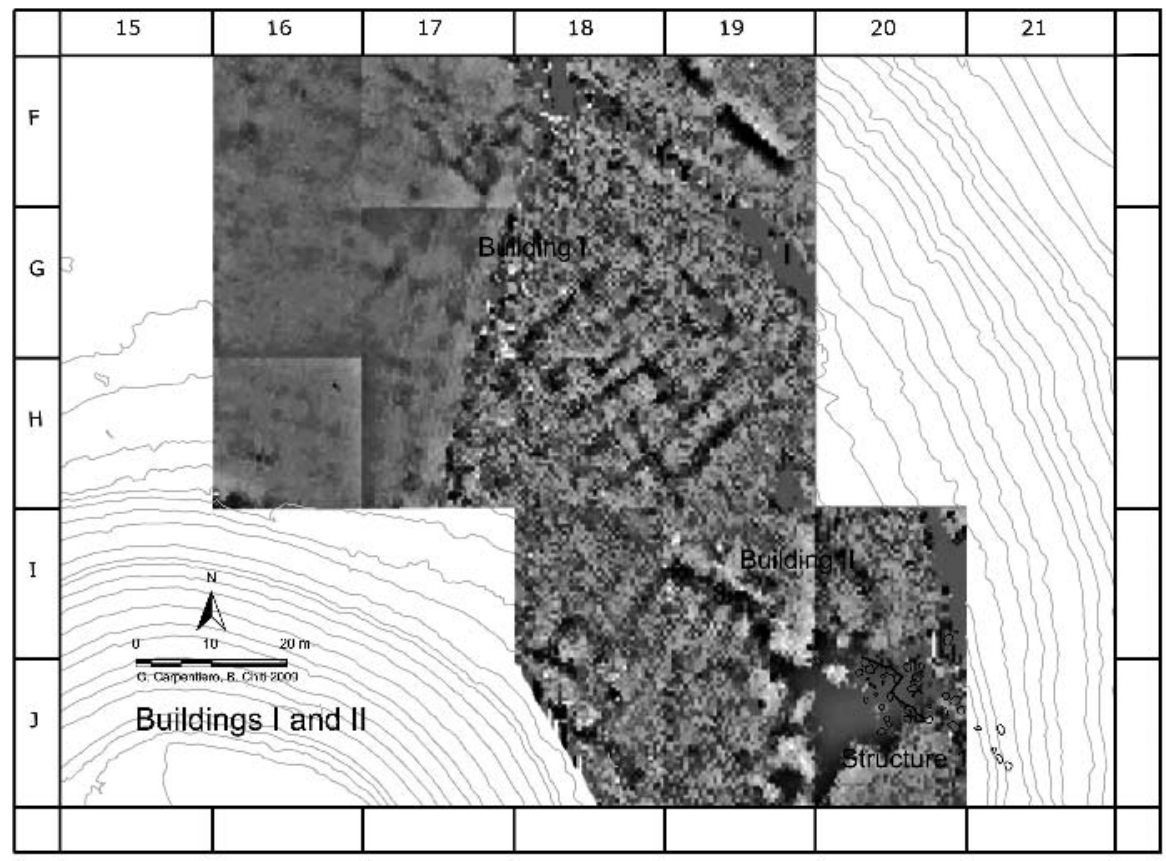

Fig. 10. Detail of the geoelectric map showing buildings I-II and the location of Structure 1 (by G. Carpentiero and B. Chiti).

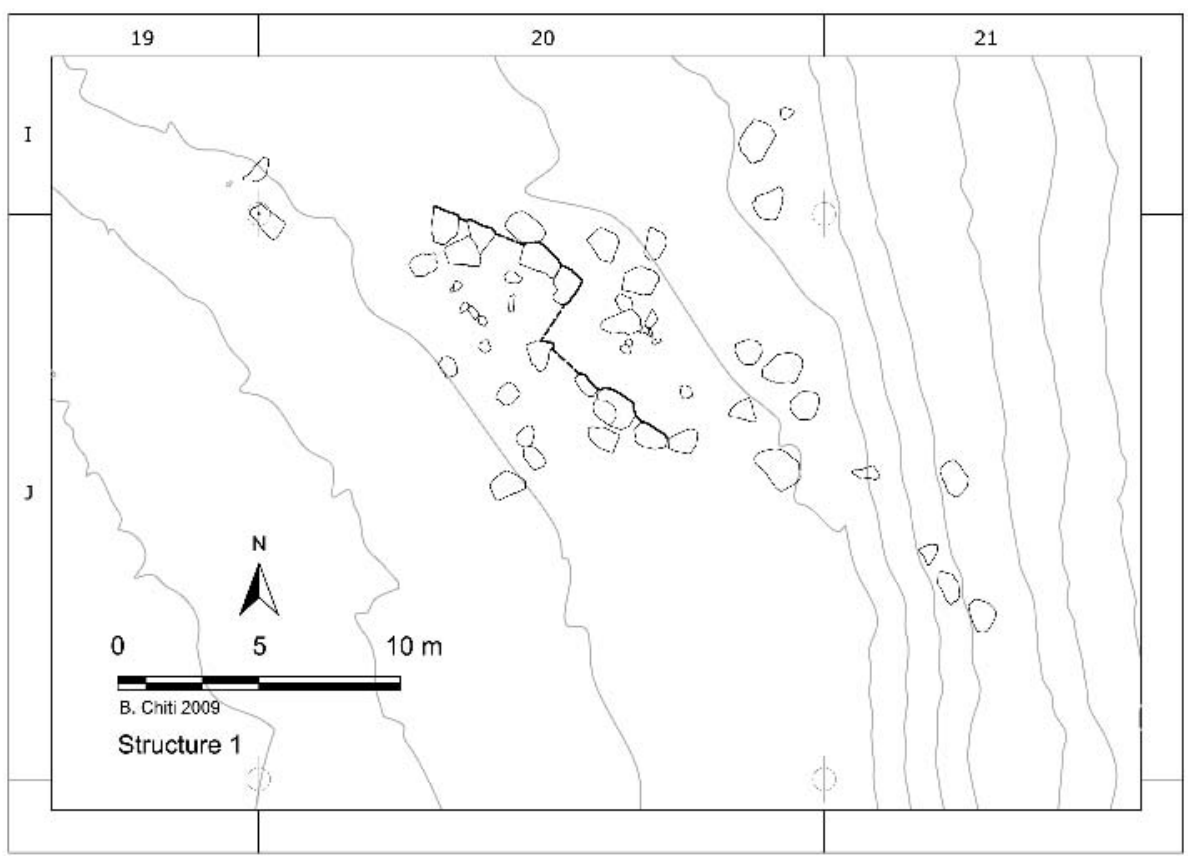

Fig. 11. Structure 1 plan (by B. Chiti). 


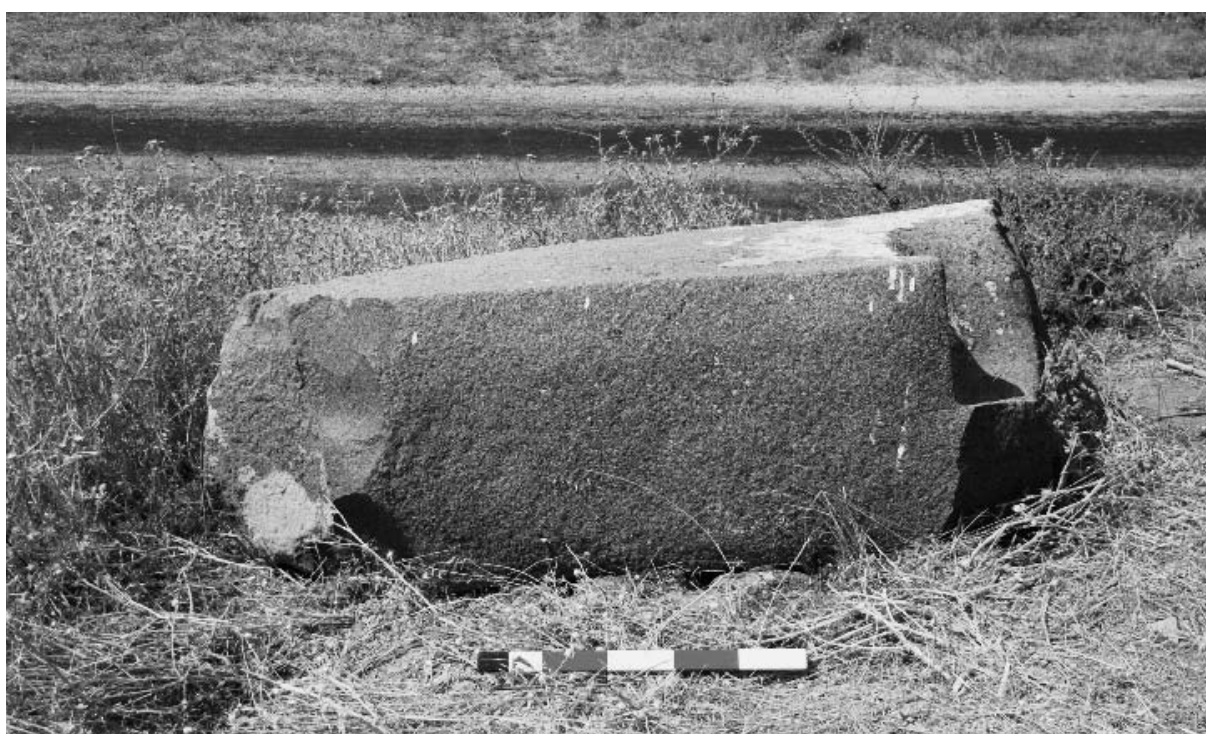

Fig. 12. Stone 2, from east.

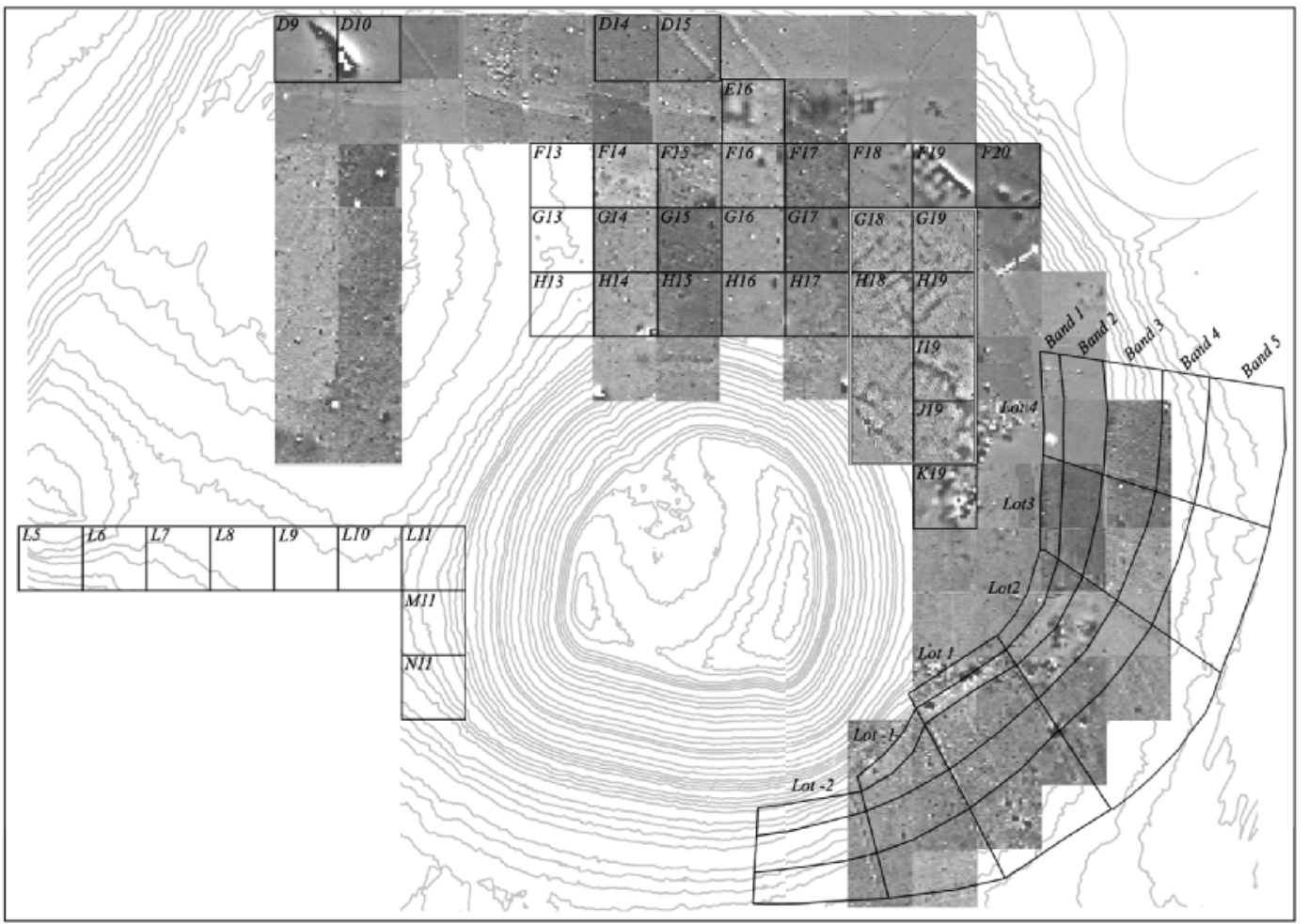

Fig. 13. Collection units. 


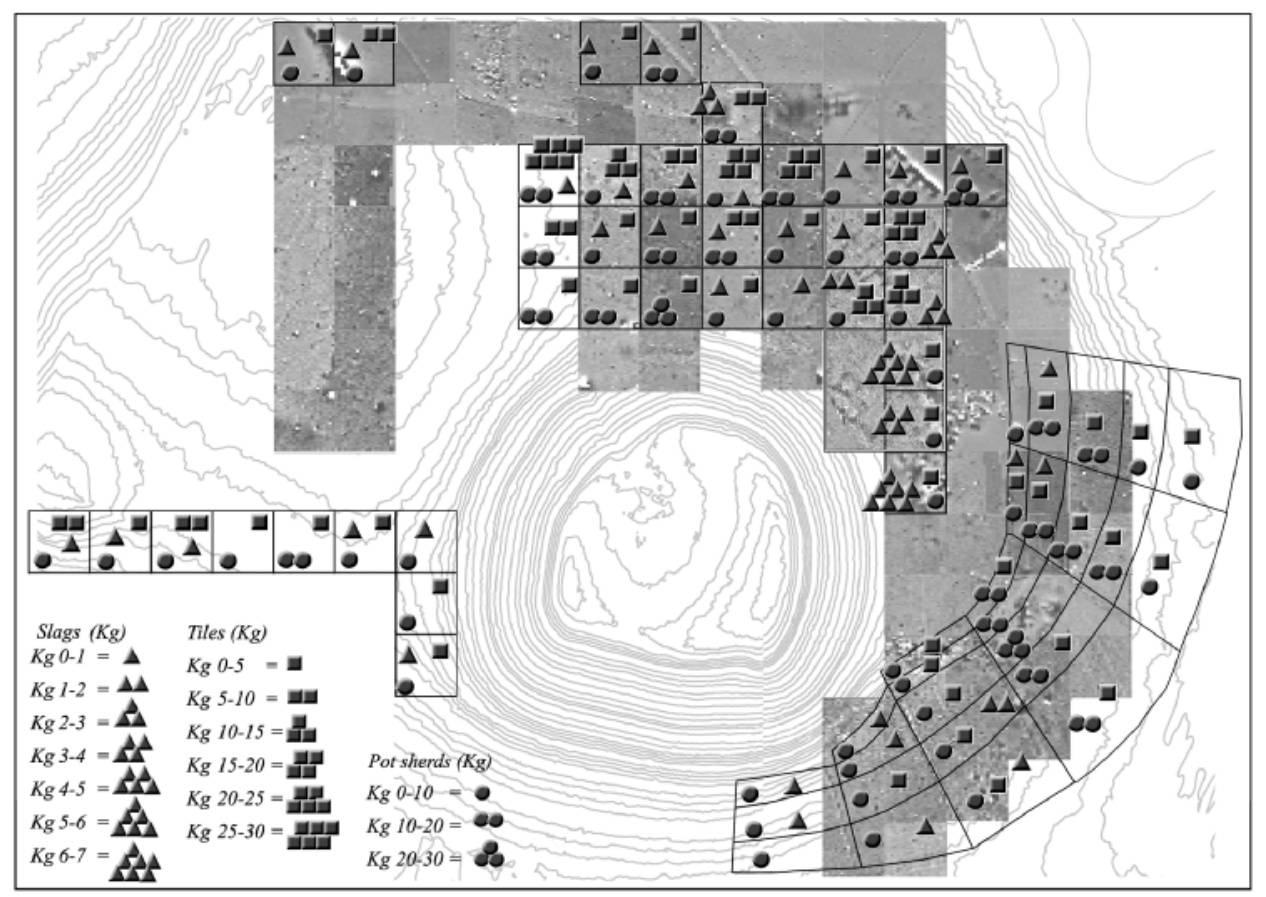

Fig. 14. Spreadsheets 1 (pot sherds, tiles, slags)

(by V. Orsi; graphics adapted from G. Carpentiero and B. Chiti plans).

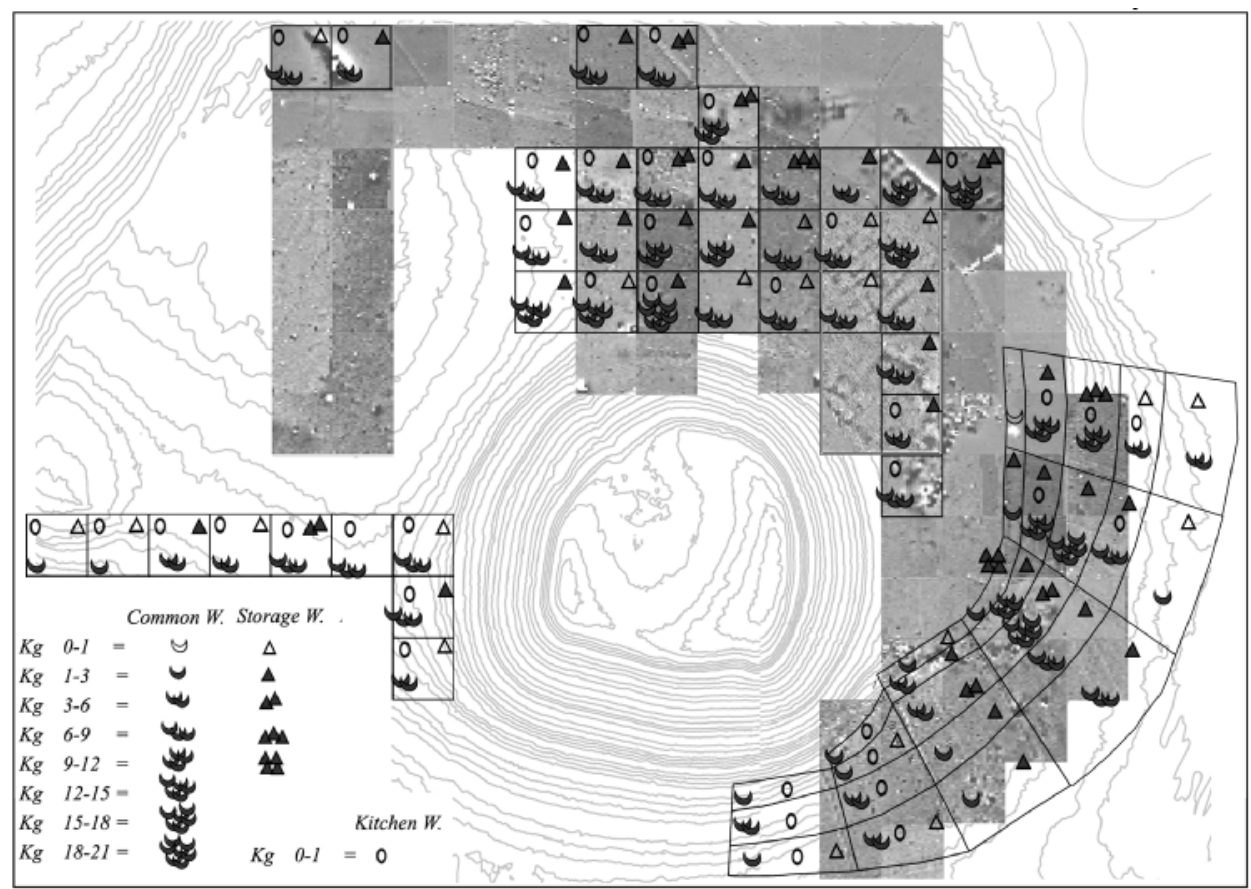

Fig. 15. Spreadsheets 2 (common, storage and kitchen wares). 


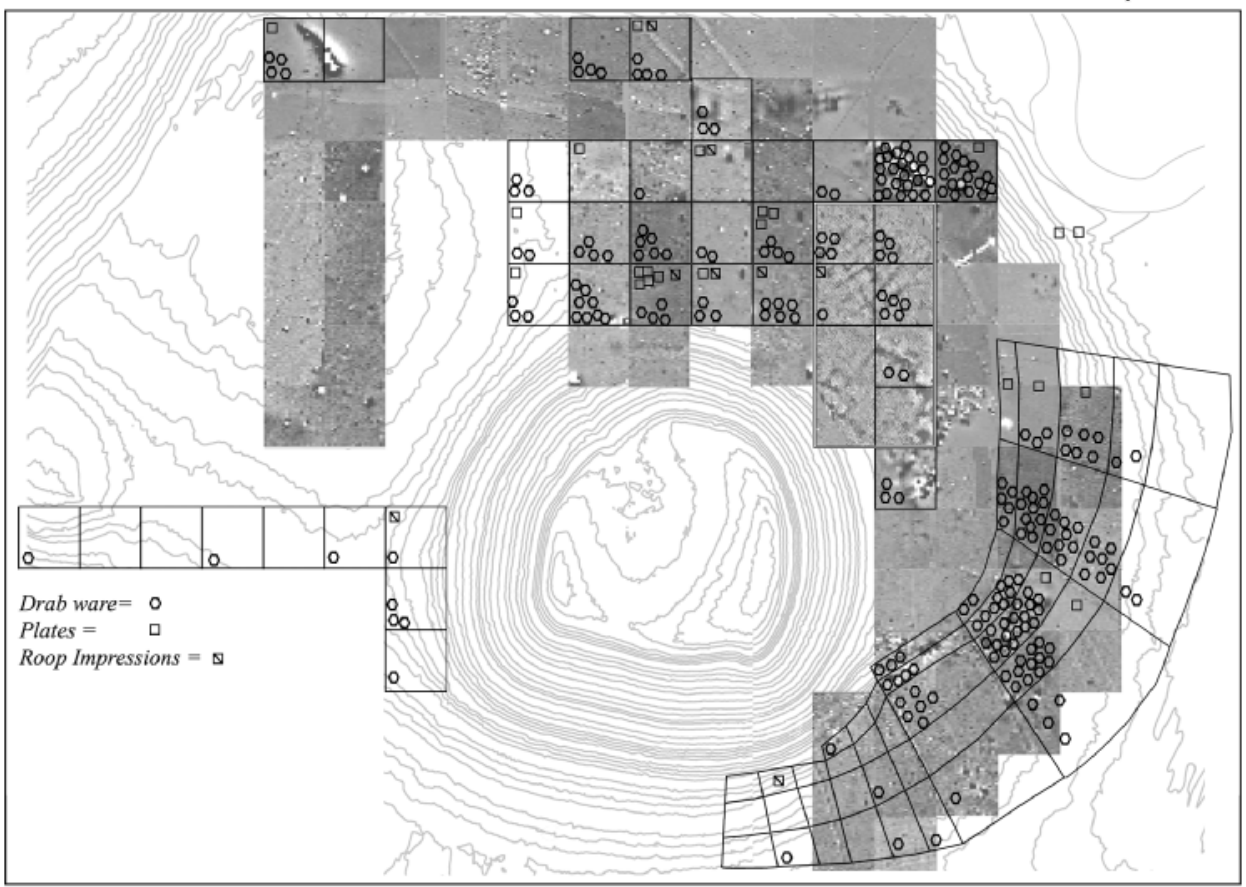

Fig. 16. Spreadsheets 3 (drab ware and plates).

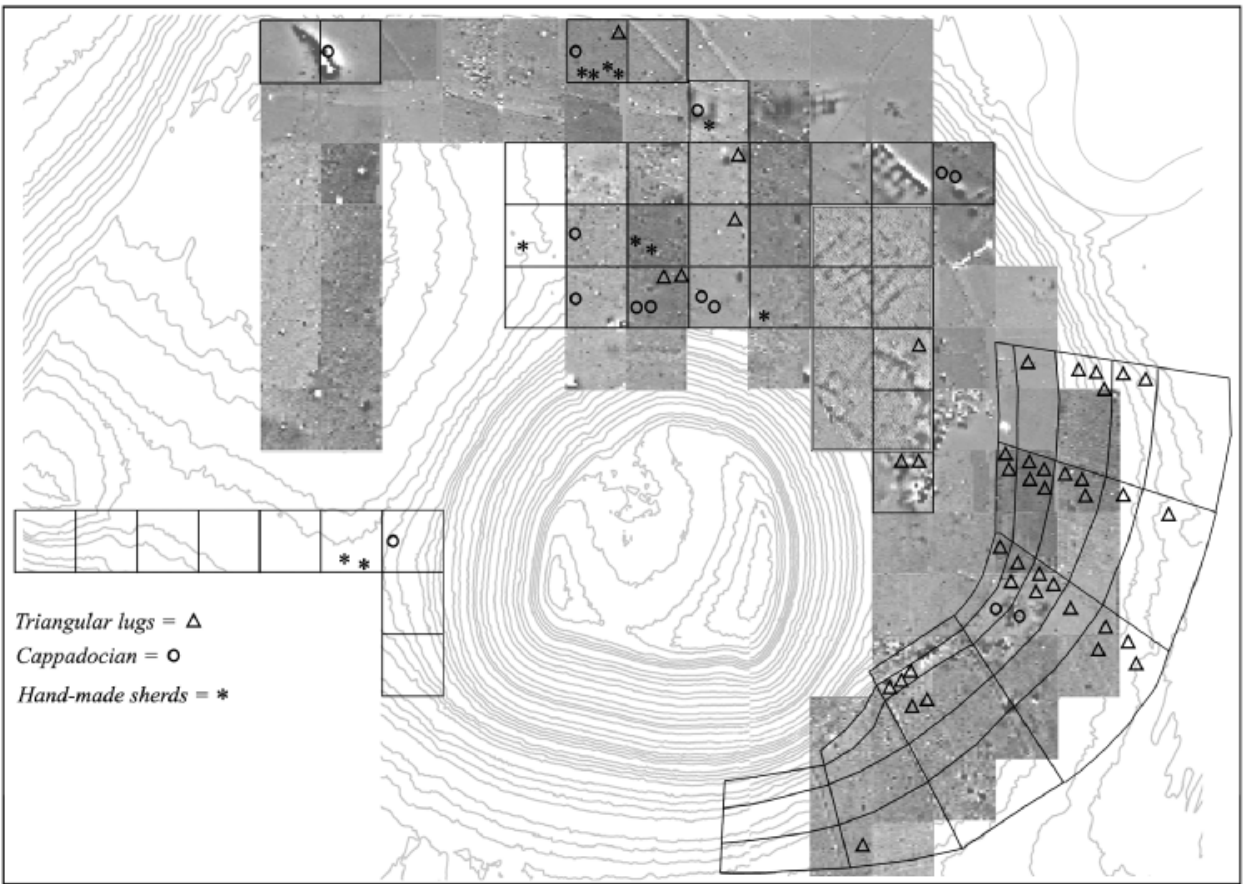

Fig. 17. Spreadsheets 4 (hand-made sherds and triangular lugs) (by V. Orsi; graphics adapted from G. Carpentiero and B. Chiti plans). 


\section{KEY TO THE POTTERY CATALOGUE}

Drawings by S. Martelli; A. D'Agostino composed the catalogue and pottery figures.

$\mathrm{n} .: \quad$ number of sherds as referred to the drawing in the figures

UKn.: inventory number

Area: square of provenience referred to topographic grid and collection units

(HM: high mound southeastern slope; TS: terrace northern slope)

$\mathrm{W} / \mathrm{Cl}$ : ware and functional class

(C: 'Cappadocian'; D: Drab; Gl: Glazed; K: Kitchen; OS: Orange Slip, 'late'; P: Plain;

PB: 'Pseudo-Brittle'; RS: Red Slip, all fragments red coated; Pf: Polychrome,

'Phrygian'; PT: Painted, Iron Age; PYS: Panted on Yellowish/White Slip, 'Phrygian' -

I - C: Common and table wares; K: Kitchen; S: Storage and long term preservation; F:

Fine and luxury wares)

E: $\quad$ texture evaluation

(FF: very fine; F: fine; MF: medium-fine; M: medium; MC: medium-coarse; C: coarse)

ST: $\quad$ surface treatment - type of coat and secondary treatment

(1: no coat/treatment; 2 : rough, summary treatment, lines of wheel are evident; 3 : selfslip; 4: slip/painting:

S: smoothed [o: horizontal lines are clearly visible]; V: sort of glazed consistence; B: burnished; P: polished)

Fa: fabric - main inclusion (V: vegetal; M: mineral; MV: mineral and vegetal) and quality of inclusions

(M1: very small grits, calcareous particles, few mica; M2: grits, middle amount of calcareous particles and mica; M3: prevailing amount of calcareous particles, grits, mica; M3b: prevailing amount of calcareous particles, grits, mica, sandy; M4: prevailing amount of mica, white grits, fine-grained sand; M5: very small grits, calcareous particles, large calcareous particles; M6: very small grits, calcareous particles, straw well minced, sandy; M8: small and medium sized white and blackish grits, mica, coarse; M9: very small grits, calcareous particles, large black grits; M10: mixed mineral inclusions and calcareous particles; M11: very small grits, calcareous particles; M12: sand, calcareous particles, mica; M14: inclusions not visible; M15: white grits, calcareous particles; M16: white and red grits, sporadic calcareous particles and mica; M17: angular red and black grits; M30: brown and reddish grits, sporadic vegetal particles;

W2: chaff and little amount of calcareous particles; W3: little sized grits and little amount of calcareous particles; W5: chaff and grits usually white)

Colours: outer and inner surface color (main color visible in surface; color of the self-slip when it is present or matrix color; in the case of slipped or painted sherds the first color before the sign + refers to the color of the painted motifs; color of the section), color of the section (main color visible in section; + nucleus color if different). Abbreviations used are referred to the Munsell Soil Color Charts.

AS: $\quad$ appearance of surface - 1: mat red-brown surface, coverage uniform; 2: lustrous, glossy redbrown surface, coverage uniform; 3: mat red-brown surface, brush traces, coverage uneven

T: $\quad H:$ hand made; W: wheel made; HW: hand made and finished on the wheel 

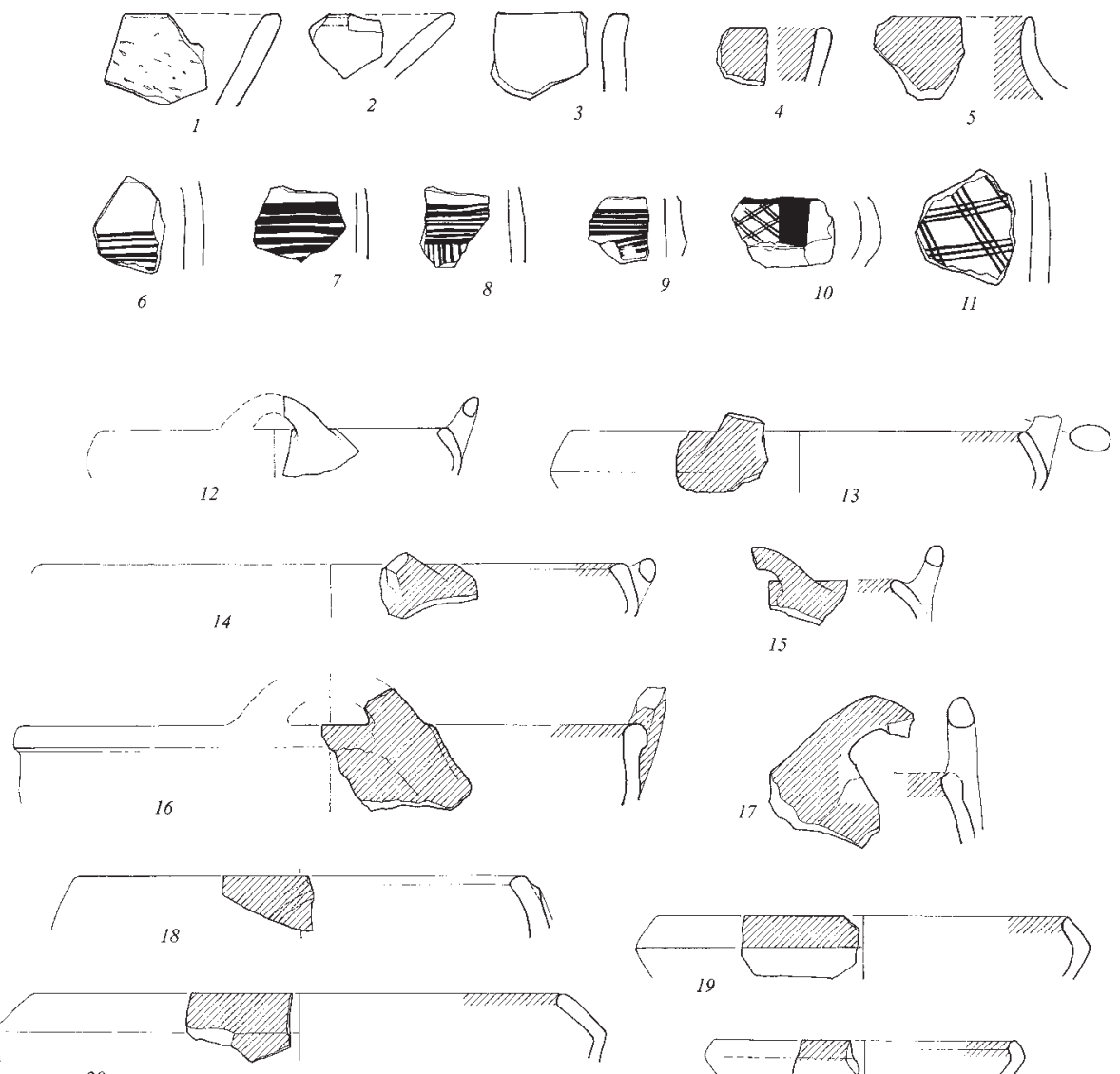

20
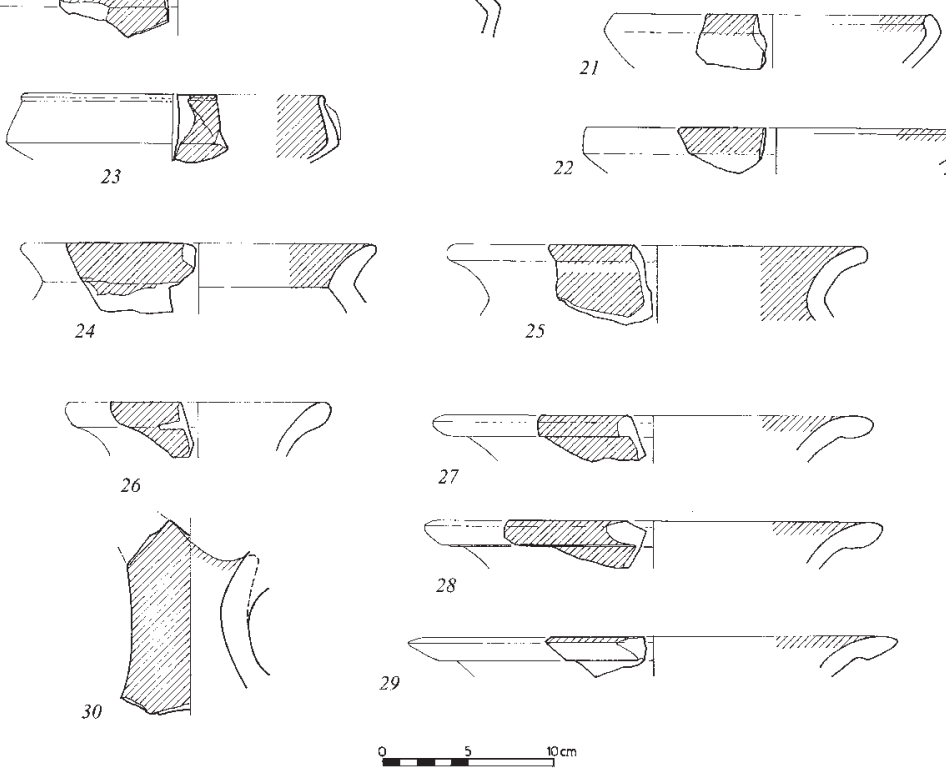

Fig. 18. Sherds dating to the Early Bronze Age-Middle Bronze Age transition (n. 1-11) and to the Middle Bronze Age/Late Bronze Age (n. 12-30). 
Fig. 18. Sherds dating to the EBA-MBA transition and to the MBA/LBA.

\begin{tabular}{|c|c|c|c|c|c|c|c|c|c|c|c|}
\hline n. & UKn. & area & $\mathbf{W} / \mathbf{C l}$ & $\mathbf{E}$ & ST & $\mathbf{F a}$ & Color (out) & Color (in) & Color (sect.) & $\mathbf{A}$ & $\mathbf{T}$ \\
\hline 1 & 09.1169 & $\mathrm{~L} 1, \mathrm{~b} 5 \mathrm{~A}$ & $\begin{array}{l}\mathrm{P} / \\
\mathrm{C}\end{array}$ & $\mathrm{M}$ & $2 \mathrm{~B}$ & $\begin{array}{l}\text { VM } \\
\text { w2 }\end{array}$ & 1.r. - 2.5 YR $6 / 6$ & 1.r. - 2.5 YR $6 / 6$ & r.y. - 5YR 6/6 & 1 & $\mathrm{H}$ \\
\hline 2 & 09.1211 & D14 & $\begin{array}{l}\mathrm{P} / \\
\mathrm{C}\end{array}$ & $\mathrm{MC}$ & 1 & $\begin{array}{l}\mathrm{Mw} \\
3\end{array}$ & br. - 7.5YR 5/3 & d.g. - 7.5 YR 4/1 & $\begin{array}{l}\text { br. }-7.5 \text { YR 5/3+ } \\
\text { d.g. - } 7.5 \text { YR 4/1 }\end{array}$ & 1 & $\mathrm{H}$ \\
\hline 3 & 09.1208 & D14 & $\begin{array}{l}\mathrm{P} / \\
\mathrm{C}\end{array}$ & M & 3 & $\begin{array}{l}\mathrm{Mw} \\
4\end{array}$ & $\begin{array}{l}\text { w.r. - } 10 \text { R } 5 / 4+ \\
\text { l.r.b. }-2.5 \text { YR } 6 / 4\end{array}$ & r.y. - 5 YR 6/6 & $\begin{array}{l}\text { 1.r. - } 2.5 \text { YR 6/8; } \\
\text { GLEY1 3/N }\end{array}$ & 1 & $\mathrm{H}$ \\
\hline 4 & 09.790 & H15 & $\mathrm{RS} / \mathrm{C}$ & M & 4Bo & Vw2 & $\begin{array}{l}\text { r. - } 10 \text { R 5/8; } \\
\text { r. - } 10 \text { R 5/6 }\end{array}$ & $\begin{array}{l}\text { r. - } 10 \text { R 5/8; } \\
\text { r. - } 10 \text { R 5/6 }\end{array}$ & $\begin{array}{l}\text { v.d.g. - GLEY1 } \\
3 / \mathrm{N}\end{array}$ & 1 & $\mathrm{H}$ \\
\hline 5 & 09.892 & E16 & $\mathrm{RS} / \mathrm{C}$ & $\mathrm{M}$ & $4 \mathrm{~B}$ & M30 & $\begin{array}{l}\text { r. - } 10 \text { R 5/6; } \\
\text { l.b. - } 7.5 \text { YR } 6 / 4\end{array}$ & $\begin{array}{l}\text { r. - } 10 \text { R 5/6; } \\
\text { r.y. - } 5 \text { YR } 6 / 6\end{array}$ & br. - 7.5 YR 5/4 & 1 & $\mathrm{H}$ \\
\hline 6 & 08.1695 & $\mathrm{~L} 3, \mathrm{~b} 3$ & $\begin{array}{l}\mathrm{C} / \\
\mathrm{C}\end{array}$ & $\mathrm{M}$ & $2 \mathrm{~B}$ & M11 & $\begin{array}{l}\text { d.r.g. - } 5 \text { YR 4/2 + } \\
\text { r.br. - } 5 \text { YR 5/4 }\end{array}$ & r.br. - 5 YR 5/4 & $\begin{array}{l}\text { r.br. - } 5 \text { YR 5/4; } \\
\text { d.g. - } 5 \text { YR 4/1 }\end{array}$ & 1 & $\mathrm{H}$ \\
\hline 7 & 09.1212 & D14 & $\begin{array}{l}\mathrm{C} / \\
\mathrm{C}\end{array}$ & M & 4B & $\begin{array}{l}\text { Mw } \\
5\end{array}$ & $\begin{array}{l}\text { p.r. }-10 \text { R } 6 / 3+ \\
\text { r. - } 10 \text { R 4/8; } \\
\text { g.br. - } 2.5 \text { Y } 5 / 6\end{array}$ & 1.r.b. - 5 YR $6 / 4$ & $\begin{array}{l}\text { l.o.b. - } 2.5 \text { Y } 5 / 6 ; \\
\text { r.b. - } 2.5 \text { YR } 2.5 / 1\end{array}$ & 1 & $\mathrm{H}$ \\
\hline 8 & 08.2203 & F20 & $\begin{array}{l}\mathrm{C} / \\
\mathrm{C}\end{array}$ & $\mathrm{M}$ & $4 \mathrm{P}$ & M3 & $\begin{array}{l}\text { b.b. - } 5 \text { PB } 2.5 / 1+ \\
\text { r. - } 10 \text { R } 5 / 6 ; \\
\text { l.r. - } 10 \text { R } 6 / 6\end{array}$ & 1.r. - 10 R $6 / 6$ & 1.r. - 10 R $6 / 6$ & 1 & $\mathrm{H}$ \\
\hline 9 & 08.1133 & TS & $\begin{array}{l}\mathrm{C} / \\
\mathrm{C}\end{array}$ & $\mathrm{M}$ & $4 \mathrm{~S}$ & M3 & $\begin{array}{l}\text { b. - } 7.5 \text { YR } 2.5 / 1+ \\
\text { p. }-7.5 \text { YR } 7 / 4 ; \\
\text { r.b. }-2 / 5 \text { YR } 4 / 3\end{array}$ & r.b. $-2 / 5$ YR $4 / 3$ & $\begin{array}{l}\text { r.b. - 2/5 YR 4/3; } \\
\text { b. - GLEY1 2.5/N }\end{array}$ & 1 & $\mathrm{H}$ \\
\hline 10 & 08.0382 & $\mathrm{~F} 20$ & $\begin{array}{l}\mathrm{C} / \\
\mathrm{C}\end{array}$ & M & 3B & M6 & $\begin{array}{l}\text { 1.b. - 7.5 YR } 6 / 3+ \\
\text { 1.b. - } 7.5 \text { YR } 6 / 4 ; \\
\text { r.y. - } 7.5 \text { YR6/6 }\end{array}$ & r.y. - 7.5 YR 6/6 & r.y. - 7.5 YR 6/6 & 1 & $\mathrm{H}$ \\
\hline 11 & 09.0801 & H15 & $\begin{array}{l}\mathrm{C} / \\
\mathrm{C}\end{array}$ & $\mathrm{M}$ & 2Bo & V2 & $\begin{array}{l}\text { W.r. - } 2.5 \text { YR 4/2 + } \\
\text { r.br. - } 5 \text { YR 5/4 }\end{array}$ & $\begin{array}{l}\text { w.r. - } 2.5 \text { YR } 4 / 2+ \\
\text { r.br. - } 5 \text { YR 5/4 }\end{array}$ & $\begin{array}{l}\text { r.br. - } 5 \text { YR 5/4; } \\
\text { g. - } 5 \text { YR 5/1 }\end{array}$ & 1 & $\mathrm{H}$ \\
\hline 12 & 08.0799 & F20 & $\begin{array}{l}\mathrm{P} / \\
\mathrm{C}\end{array}$ & $\mathrm{F}$ & $4 \mathrm{~B}$ & M11 & $\begin{array}{l}\text { r.br. - } 5 \text { YR 5/3; } \\
\text { r.y. - } 5 \text { YR 6/6 }\end{array}$ & 5 YR 6/6 & YR 6/6 & 1 & W \\
\hline 13 & 08.2109 & L4,b4 & $\begin{array}{l}\mathrm{RS} / \\
\mathrm{C}\end{array}$ & $\mathrm{M}$ & $4 \mathrm{~S}$ & M3 & $\begin{array}{l}\text { w.r. - } 10 \text { R } 5 / 4 ; \\
\text { r. - } 2.5 \text { YR 5/6 }\end{array}$ & $\begin{array}{l}\text { W.r. - } 10 \text { R 5/4; } \\
\text { r. - } 2.5 \text { YR 5/6 }\end{array}$ & $\begin{array}{l}\text { r. - 2.5 YR 5/6; } \\
\text { g. - GLEY1 6/N }\end{array}$ & 1 & W \\
\hline 14 & 08.1821 & $\mathrm{~L} 3, \mathrm{~b} 4$ & $\mathrm{RS} / \mathrm{C}$ & M & $4 \mathrm{P}$ & M11 & $\begin{array}{l}\text { r. - } 10 \text { R 4/8; } \\
\text { w.r. - } 10 \text { R 5/4 }\end{array}$ & $\begin{array}{l}\text { r. - } 10 \text { R 4/8; } \\
\text { w.r. - } 10 \text { R 5/4 }\end{array}$ & w.r. - 10 R 5/4 & 1 & W \\
\hline 15 & 08.1566 & $\mathrm{~L} 3, \mathrm{~b} 2$ & $\begin{array}{l}\mathrm{RS} / \\
\mathrm{C}\end{array}$ & $\mathrm{F}$ & $4 \mathrm{~B}$ & M11 & $\begin{array}{l}\text { w.r. - } 10 \text { R 5/4; } \\
\text { y.r. - } 5 \text { YR 5/6; }\end{array}$ & $\begin{array}{l}\text { w.r. - } 10 \text { R 5/4; } \\
\text { y.r. - } 5 \text { YR 5/6; }\end{array}$ & 5 YR 5/6; & 1 & W \\
\hline 16 & 09.0002 & $\mathrm{~L} 1, \mathrm{~b} 2$ & $\mathrm{RS} / \mathrm{C}$ & M & 4B & $\begin{array}{l}\text { M3 } \\
\text { B }\end{array}$ & $\begin{array}{l}\text { W.r. - } 10 \text { R } 4 / 4 ; \\
\text { br. - } 7.5 \text { YR 5/3 }\end{array}$ & $\begin{array}{l}\text { g. - } 7.5 \text { YR 5/1; } \\
\text { br. - } 7.5 \text { YR 5/3 }\end{array}$ & d.r.g. - 10 YR 4/1 & 1 & W \\
\hline 17 & 08.1626 & $\mathrm{~L} 3, \mathrm{~b} 2$ & $\begin{array}{l}\mathrm{RS} / \\
\mathrm{C}\end{array}$ & M & $4 \mathrm{~S}$ & M11 & $\begin{array}{l}\text { w.r. - } 10 \text { R 5/4; } \\
\text { r. - } 2.5 \text { YR 5/6 }\end{array}$ & $\begin{array}{l}\text { W.r. - } 10 \text { R 5/4; } \\
\text { r. - } 2.5 \text { YR 5/6 }\end{array}$ & $\begin{array}{l}\text { r. - 2.5 YR 5/6; } \\
\text { d.g. - GLEY1 4/N }\end{array}$ & 1 & W \\
\hline 18 & 08.0846 & J19 & $\mathrm{RS} / \mathrm{C}$ & M & 4B & M11 & $\begin{array}{l}\text { w.r. - 10R 5/4; } \\
\text { r.br. - } 5 \text { YR 5/3; }\end{array}$ & r.br. - 5 YR 5/3 & $\begin{array}{l}\text { r.br. - } 5 \text { YR 5/3; } \\
\text { d.g. - GLEY1 4/N }\end{array}$ & 1 & $\mathrm{~W}$ \\
\hline 19 & 08.574 & H19 & $\begin{array}{l}\mathrm{RS} / \\
\mathrm{C}\end{array}$ & M & 4B & M3 & $\begin{array}{l}\text { r. }-2.5 \text { YR 5/6; } \\
\text { l.r.b. - } 2.5 \text { YR 6/4 }\end{array}$ & $\begin{array}{l}\text { r. }-2.5 \text { YR 5/6; } \\
\text { l.r.b. - } 2.5 \text { YR } 6 / 4\end{array}$ & $\begin{array}{l}\text { l.r.b. - } 2.5 \text { YR 6/4; } \\
\text { g. - GLEY1 5/N }\end{array}$ & 1 & W \\
\hline 20 & 08.1392 & L2,b4 & $\begin{array}{l}\mathrm{RS} / \\
\mathrm{C}\end{array}$ & $\mathrm{F}$ & 4 & M11 & $\begin{array}{l}\text { w.r. - } 10 \text { R 5/4; } \\
\text { l.r. - } 2.5 \text { YR } 6 / 6\end{array}$ & $\begin{array}{l}\text { w.r. - } 10 \text { R } 5 / 4 ; \\
\text { l.r. - } 2.5 \text { YR } 6 / 6\end{array}$ & $\begin{array}{l}\text { l.r. - 2.5 YR 6/6; } \\
\text { d.g. - GLEY1 4/N }\end{array}$ & 1 & $\mathrm{~W}$ \\
\hline 21 & 08.1558 & $\mathrm{~L} 3, \mathrm{~b} 2$ & $\begin{array}{l}\mathrm{RS} / \\
\mathrm{C}\end{array}$ & M & 4 & M3 & $\begin{array}{l}\text { w.r. - } 10 \text { R 5/4; } \\
\text { r. - } 2.5 \text { YR 5/6 }\end{array}$ & $\begin{array}{l}\text { w.r. - } 10 \text { R 5/4; } \\
\text { r. - } 2.5 \text { YR 5/6 }\end{array}$ & $\begin{array}{l}\text { r. - } 2.5 \text { YR 5/6; } \\
\text { d.g. - GLEY1 4/N }\end{array}$ & 1 & $\mathrm{~W}$ \\
\hline 22 & 08.1097 & $\mathrm{~L} 2, \mathrm{~b} 2$ & $\begin{array}{l}\mathrm{RS} / \\
\mathrm{C}\end{array}$ & $\mathrm{M}$ & 4B & M11 & $\begin{array}{l}\text { r. - } 10 \text { R 5/6; } \\
\text { r.br. - } 5 \text { YR 5/4 }\end{array}$ & $\begin{array}{l}\text { r. - } 10 \text { R 5/6; } \\
\text { r.br. - } 5 \text { YR 5/4 }\end{array}$ & r.br. - 5 YR 5/4 & 1 & W \\
\hline 23 & 09.0001 & $\mathrm{~L} 1, \mathrm{~b} 2$ & $\mathrm{RS} / \mathrm{F}$ & $\mathrm{F}$ & $4 \mathrm{~B}$ & M12 & $\begin{array}{l}\text { w.r. - } 10 \text { R 4/4; } \\
\text { br. - } 7.5 \text { YR 5/3 }\end{array}$ & $\begin{array}{l}\text { w.r. - 10R4/4; } \\
\text { br. - 7.5 YR 5/3 B }\end{array}$ & g. - 7.5 YR 5/1 & 1 & W \\
\hline 24 & 08.1128 & $\mathrm{~L} 2, \mathrm{~b} 2$ & $\mathrm{RS} / \mathrm{C}$ & $\mathrm{M}$ & $4 \mathrm{~S}$ & M5 & $\begin{array}{l}\text { r. - } 10 \text { R 5/6; } \\
\text { w.r. - } 10 \text { R 5/4 }\end{array}$ & $\begin{array}{l}\text { r. - } 10 \text { R 5/6; } \\
\text { w.r. - } 10 \text { R 5/4 }\end{array}$ & w.r. - 10 R 5/4 & 1 & W \\
\hline 25 & 08.1231 & $\mathrm{~L} 2, \mathrm{~b} 3$ & $\mathrm{RS} / \mathrm{C}$ & M & $4 \mathrm{~S}$ & M11 & $\begin{array}{l}\text { l.r. - } 10 \text { R } 6 / 6 \text {; } \\
\text { r.br. - } 5 \text { YR 5/4 }\end{array}$ & $\begin{array}{l}\text { l.r. - } 10 \text { R } 6 / 6 \text {; } \\
\text { r.br. - } 5 \text { YR 5/4 }\end{array}$ & r.br. - 5 YR 5/4 & 1 & W \\
\hline 26 & 08.1467 & $\mathrm{~L} 2, \mathrm{~b} 5$ & $\mathrm{RS} / \mathrm{C}$ & $\mathrm{F}$ & 4B & M11 & $\begin{array}{l}\text { W.r. - } 10 \text { R } 5 / 4 ; \\
\text { r. - } 2.5 \text { YR 5/8 }\end{array}$ & $\begin{array}{l}\text { W.r. - } 10 \text { R } 5 / 4 ; \\
\text { r. - } 2.5 \text { YR 5/8 }\end{array}$ & r. -2.5 YR 5/8 & 1 & W \\
\hline 27 & 08.0728 & I19 & $\begin{array}{l}\mathrm{RS} / \\
\mathrm{C}\end{array}$ & $\mathrm{M}$ & 4B & M11 & $\begin{array}{l}\text { p.r. }-10 \text { R } 6 / 4 \text {; } \\
\text { r. - } 2.5 \text { YR } 5 / 6\end{array}$ & $\begin{array}{l}\text { W.r. - } 10 \text { R } 5 / 4 ; \\
\text { r. - } 2.5 \text { YR 5/6; }\end{array}$ & r. - 2.5 YR 5/6 & 1 & W \\
\hline 28 & 08.2030 & $\mathrm{~L} 4, \mathrm{~b} 3$ & $\mathrm{RS} / \mathrm{C}$ & M & $4 \mathrm{~B}$ & M3 & $\begin{array}{l}\text { w.r. - } 10 \text { R 4/3; } \\
\text { d.g. - } 7.5 \text { YR 4/1 }\end{array}$ & $\begin{array}{l}\text { w.r. - } 10 \text { R 4/4; } \\
\text { d.g. - } 7.5 \text { YR 4/1 }\end{array}$ & d.g. - 7.5 YR 4/1 & 1 & W \\
\hline 29 & 08.1760 & $\mathrm{~L} 3, \mathrm{~b} 3$ & $\mathrm{RS} / \mathrm{C}$ & $\mathrm{M}$ & $4 \mathrm{~S}$ & M5 & $\begin{array}{l}\text { w.r. - } 10 \text { R 4/3; } \\
\text { r.br. - } 5 \text { YR 5/4 }\end{array}$ & r.br. - 5 YR 5/4 & r.br. - 5 YR 5/4 & 1 & W \\
\hline 30 & 09.1277 & $\mathrm{~L} 2, \mathrm{~b} 2$ & $\mathrm{RS} / \mathrm{F}$ & MF & $4 \mathrm{P}$ & M3 & $\begin{array}{l}\text { r. - 2.5 YR 4/6; } \\
\text { 1.r. - 2.5 YR 6/6 }\end{array}$ & $\begin{array}{l}\text { r. }-2.5 \text { YR 4/6+ } \\
\text { v.p.b. }-10 \text { YR } 8 / 4\end{array}$ & 1.r. - 2.5 YR 6/6 & 2 & WH \\
\hline
\end{tabular}



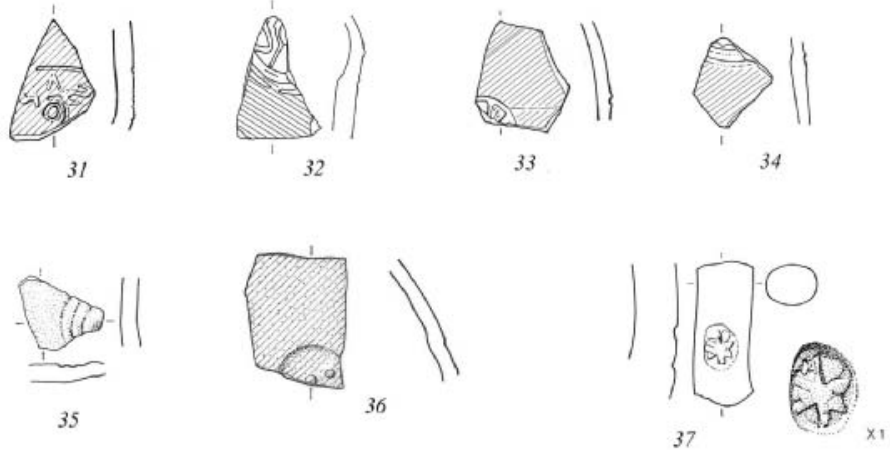

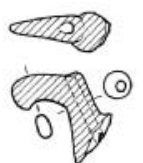

38

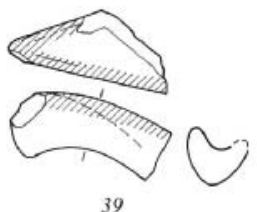

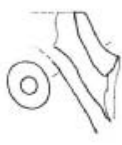

40
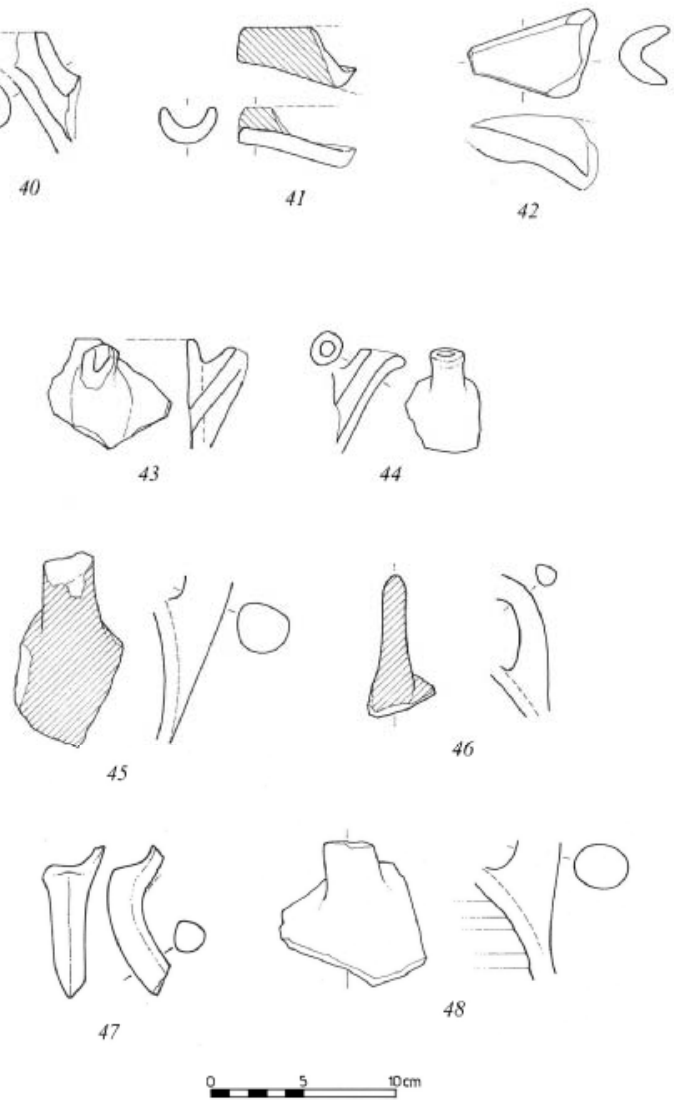

Fig. 19. Sherds dating to the Middle Bronze Age/Late Bronze Age (31-48). 
Fig. 19. Sherds dating to the Middle Bronze Age/Late Bronze Age.

\begin{tabular}{|c|c|c|c|c|c|c|c|c|c|c|c|}
\hline n. & UKn. & area & $\mathbf{W} / \mathbf{C l}$ & $\mathbf{E}$ & ST & $\mathbf{F a}$ & Color (out) & Color (in) & Color (sect.) & $\mathbf{A}$ & $\mathbf{T}$ \\
\hline 31 & 09.0008 & F19 & $\begin{array}{l}\mathrm{RS} / \\
\mathrm{C}\end{array}$ & MF & 4 & M1 & $\begin{array}{l}\text { r. - } 10 \text { R 5/6; } \\
\text { l.b. - } 7.5 \text { YR 6/4 }\end{array}$ & 1.b. - 7.5 YR $6 / 4$ & br. - 7.5 YR 5/2 & 1 & W \\
\hline 32 & 08.0432 & G19 & $\begin{array}{l}\mathrm{RS} / \\
\mathrm{C}\end{array}$ & $\mathrm{F}$ & $4 \mathrm{~S}$ & M1 & $\begin{array}{l}\text { w.r. - } 10 \text { R 4/4; } \\
\text { v.d.g. - GLEY1 3/N }\end{array}$ & $\begin{array}{l}\text { v.d.g. - GLEY1 } \\
3 / \mathrm{N}\end{array}$ & $\begin{array}{l}\text { v.d.g. - GLEY1 } \\
3 / \mathrm{N}\end{array}$ & 1 & W \\
\hline 33 & 08.0858 & $\mathrm{~L} 1, \mathrm{~b} 1$ & $\begin{array}{l}\mathrm{RS} / \\
\mathrm{C}\end{array}$ & M & 4 & M3 & $\begin{array}{l}\text { r. - } 10 \text { R 5/6; } \\
\text { r.y. - 5YR6/6 }\end{array}$ & r.y. - 5 YR 6/6 & $\begin{array}{l}\text { r.y. - } 5 \text { Y R 6/6; } \\
\text { d.g. - GLEY1 4/N }\end{array}$ & 1 & W \\
\hline 34 & 08.1907 & $\mathrm{~L} 4, \mathrm{~b} 1$ & $\begin{array}{l}\mathrm{RS} / \\
\mathrm{C}\end{array}$ & $\mathrm{F}$ & 4 & M11 & $\begin{array}{l}\text { r. - } 10 \text { R 5/6; } \\
\text { r.br. - } 5 \text { YR 5/4 }\end{array}$ & $\begin{array}{l}\text { r. - } 10 \text { R 5/6; } \\
\text { r.br. - } 5 \text { YR 5/4 }\end{array}$ & r.br. - 5 YR 5/4 & 1 & W \\
\hline 35 & 08.1243 & $\mathrm{~L} 2, \mathrm{~b} 3$ & $\begin{array}{l}\mathrm{RS} / \\
\mathrm{C}\end{array}$ & $\mathrm{F}$ & $4 \mathrm{~S}$ & M11 & $\begin{array}{l}\text { w.r. - } 10 \text { R } 5 / 4 ; \\
\text { y.r. - } 5 \text { YR 5/6 }\end{array}$ & y.r. - 5 YR 5/6 & y.r. - 5 YR 5/6 & 1 & $\mathrm{~W}$ \\
\hline 36 & 09.1256 & HM & $\begin{array}{l}\mathrm{RS} / \\
\mathrm{C}\end{array}$ & MF & $4 \mathrm{BV}$ & M & $\begin{array}{l}\text { r. - } 10 \text { R } 4 / 6 ; \\
\text { p.r. - pi.r. - } 10 \text { R } 6 / 4\end{array}$ & p.g. - 7.5 YR $6 / 2$ & 1.b. - 7.5 YR $6 / 4$ & 2 & W \\
\hline 37 & 08.1793 & $\mathrm{~L} 3, \mathrm{~b} 4$ & $\begin{array}{l}\mathrm{P} / \\
\mathrm{C}\end{array}$ & $\mathrm{F}$ & 1 & M11 & r.y. - 5 YR 6/6 & r.y. - 5 YR 6/6 & $\begin{array}{l}\text { r.y. - } 5 \text { YR 6/6; } \\
\text { l.g. - GLEY 7/N }\end{array}$ & 1 & $\mathrm{H}$ \\
\hline 38 & 09.1279 & $\mathrm{~L} 3, \mathrm{~b} 3$ & $\mathrm{RS} / \mathrm{F}$ & $\mathrm{F}$ & $4 \mathrm{P}$ & M10 & $\begin{array}{l}\text { y.r. - } 5 \text { YR } 4 / 6 ; \\
\text { p. - } 5 \text { YR } 7 / 4\end{array}$ & p. -5 YR 7/4 & p. - 5 YR 7/4 & 2 & $\mathrm{H}$ \\
\hline 39 & 09.0003 & $\mathrm{~L} 1, \mathrm{~b} 2$ & $\begin{array}{l}\mathrm{RS} / \\
\mathrm{C}\end{array}$ & M & $4 \mathrm{~B}$ & M3 & $\begin{array}{l}\text { r. }-2.5 \text { YR 5/6+ } \\
\text { l.r.b. - } 5 \text { YR } 6 / 4\end{array}$ & $\begin{array}{l}\text { r. }-2.5 \text { YR } 5 / 6+ \\
\text { l.r.b. } 5 \text { YR } 6 / 4\end{array}$ & br. - 7.5 YR 5/4 & 1 & $\mathrm{H}$ \\
\hline 40 & 08.0424 & TS & $\begin{array}{l}\mathrm{RS} / \\
\mathrm{C}\end{array}$ & $\mathrm{F}$ & $4 \mathrm{P}$ & M11 & $\begin{array}{l}\text { r. - } 10 \text { R 4/6; } \\
\text { r.y. - } 5 \text { YR 6/6 }\end{array}$ & r.y. - 5 YR 6/6 & r.y. - 5 YR 6/6 & 1 & $\mathrm{H}$ \\
\hline 41 & 08.0291 & F20 & $\begin{array}{l}\mathrm{RS} / \\
\mathrm{C}\end{array}$ & $\mathrm{F}$ & $4 \mathrm{~B}$ & M11 & $\begin{array}{l}\text { r. - } 10 \text { R 4/6; } \\
\text { r.br. - } 5 \text { YR 5/4 }\end{array}$ & r.br. - 5 YR 5/4 & r.br. - 5 YR 5/4 & 1 & $\mathrm{H}$ \\
\hline 42 & 08.1943 & $\mathrm{~L} 4, \mathrm{~b} 2$ & $\mathrm{C}$ & M & $3 \mathrm{~B}$ & M3 & r. -2.5 YR 5/6 & r. -2.5 YR 5/6 & r. -2.5 YR 5/6 & 1 & $\mathrm{H}$ \\
\hline 43 & 08.1106 & $\mathrm{~L} 2, \mathrm{~b} 2$ & $\begin{array}{l}\mathrm{P} / \\
\mathrm{C}\end{array}$ & M & 3 & M11 & y.r. - 5 YR 5/6 & y.r. - 5 YR 5/6 & $\begin{array}{l}\text { y.r. - } 5 \text { YR 5/6; } \\
\text { r.br. - } 5 \text { YR 5/4 }\end{array}$ & 1 & $\mathrm{H}$ \\
\hline 44 & 08.1245 & $\mathrm{~L} 2, \mathrm{~b} 3$ & $\begin{array}{l}\mathrm{P} / \\
\mathrm{C}\end{array}$ & M & 2 & M11 & r.br. - 5 YR 5/4 & r.br. - 5 YR 5/4 & $\begin{array}{l}\text { r.br. - } 5 \text { YR 5/4; } \\
\text { g. - GLEY1 5/N }\end{array}$ & 1 & $\mathrm{H}$ \\
\hline 45 & 08.0547 & $\mathrm{TS}$ & $\begin{array}{l}\mathrm{RS} / \\
\mathrm{C}\end{array}$ & M & $4 \mathrm{~S}$ & M11 & $\begin{array}{l}\text { w.r. - } 10 \text { R 5/4; } \\
\text { l.r. - } 2.5 \text { YR 6/6 }\end{array}$ & $\begin{array}{l}\text { b. - GLEY1 } \\
2.5 / \mathrm{N}\end{array}$ & $\begin{array}{l}\text { 1.r. - } 2.5 \text { YR 6/6; } \\
\text { b. - GLEY1 2.5/N }\end{array}$ & 1 & $\mathrm{H}$ \\
\hline 46 & 08.0816 & F20 & $\begin{array}{l}\mathrm{RS} / \\
\mathrm{C}\end{array}$ & $\mathrm{F}$ & $4 \mathrm{~B}$ & M3 & $\begin{array}{l}\text { r. - } 10 \text { R 4/6; } \\
\text { r.y. - } 5 \text { YR 6/6 }\end{array}$ & r.y. - 5 YR 6/6 & r.y. - 5 YR 6/6 & 1 & $\mathrm{H}$ \\
\hline 47 & 09.1280 & $\mathrm{~L} 3, \mathrm{~b} 3$ & $\mathrm{RS} / \mathrm{F}$ & $\mathrm{FF}$ & $4 \mathrm{P}$ & M14 & $\begin{array}{l}\text { y.r. - } 5 \text { YR 5/6; } \\
\text { l.r.b. - } 5 \text { YR 6/3 }\end{array}$ & 1.r.b. - 5 YR $6 / 3$ & 1.r.b. - 5 YR $6 / 3$ & 2 & $\mathrm{H}$ \\
\hline 48 & 08.0853 & TS & $\begin{array}{l}\mathrm{P} / \\
\mathrm{C}\end{array}$ & $\mathrm{MF}$ & $2 \mathrm{~S}$ & M11 & r.y. - 5 YR 6/6 & r.y. - 5 YR 6/6 & $\begin{array}{l}\text { r.y. - } 5 \text { YR 6/6; } \\
\text { g. - GLEY1 5/N }\end{array}$ & 1 & $\mathrm{H}$ \\
\hline
\end{tabular}



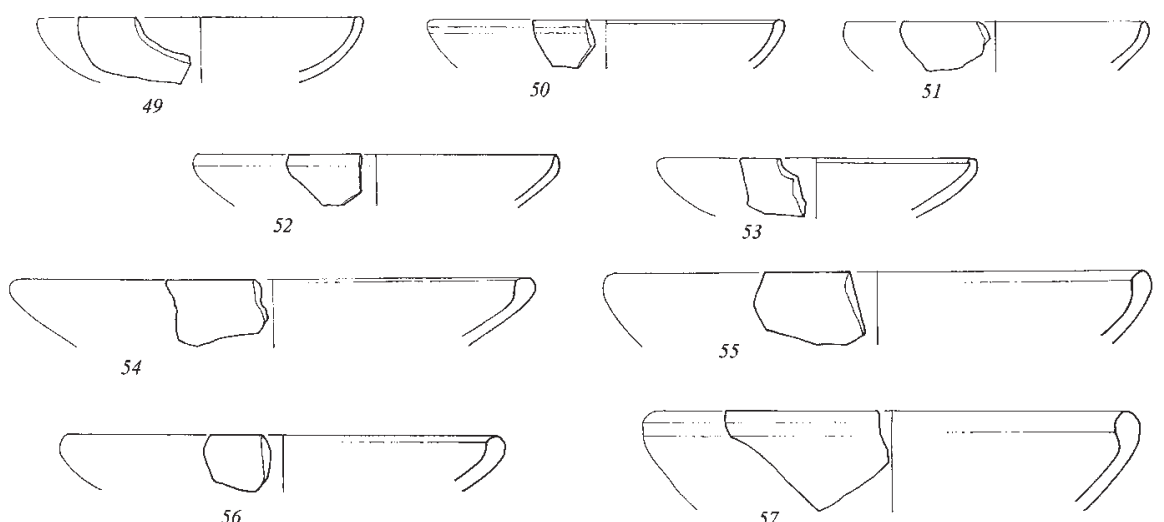

56
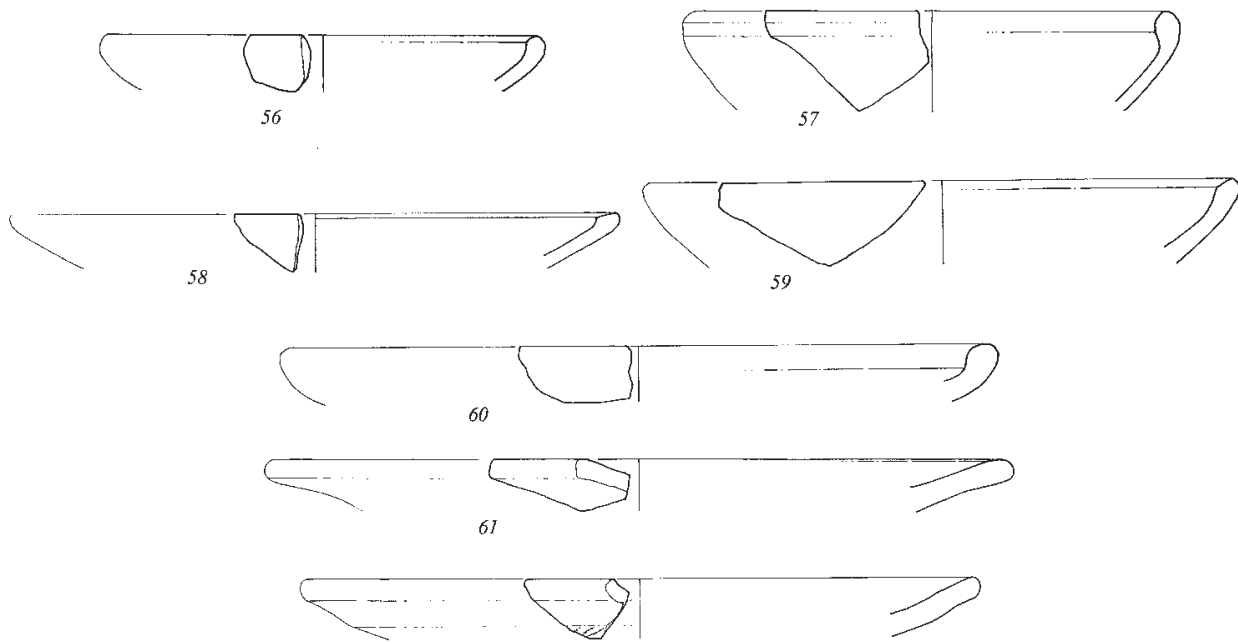

62
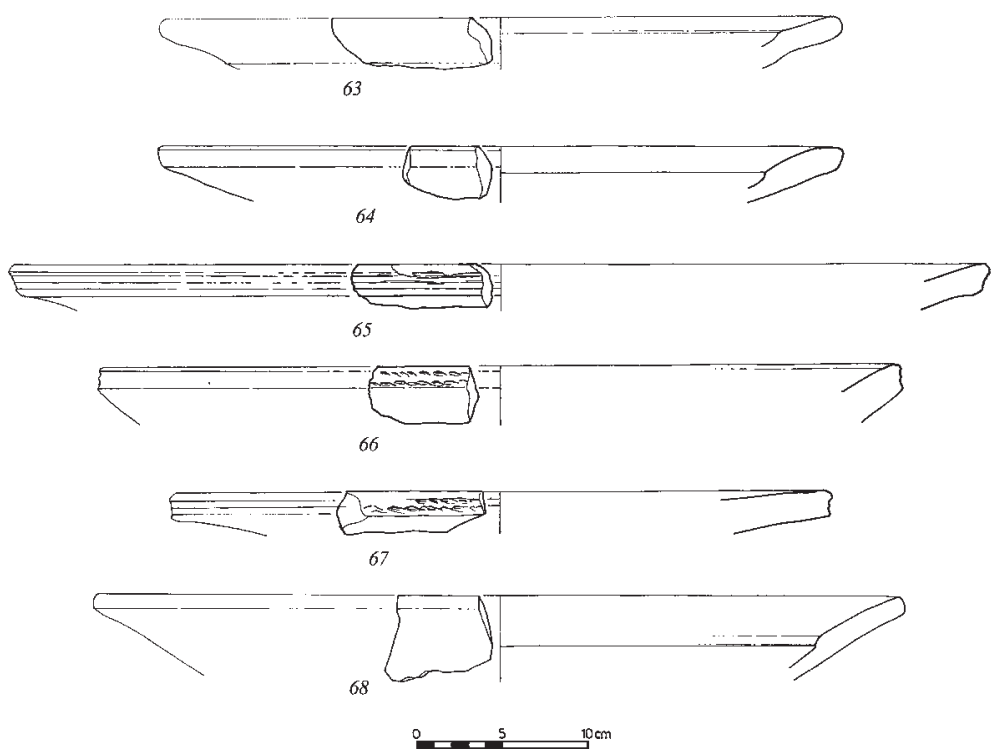

Fig. 20. Sherds dating to the Late Bronze Age. 
Fig. 20. Sherds dating to the Late Bronze Age.

\begin{tabular}{|c|c|c|c|c|c|c|c|c|c|c|c|}
\hline n. & UKn. & area & $\mathbf{W} / \mathbf{C l}$ & $\mathbf{E}$ & ST & $\mathbf{F a}$ & Color (out) & Color (in) & Color (sect.) & $\mathbf{A}$ & $\mathbf{T}$ \\
\hline 49 & 08.1019 & $\mathrm{~L} 2, \mathrm{~b} 2$ & $\begin{array}{l}\mathrm{D} / \\
\mathrm{C}\end{array}$ & $\mathrm{F}$ & 2So & M11 & r.br. - 5 YR 5/3 & r.br. - 5 YR 5/3 & r.br. - 5 YR 5/3 & 1 & $\mathrm{~W}$ \\
\hline 50 & 09.0423 & G16 & $\begin{array}{l}\mathrm{P} / \\
\mathrm{C}\end{array}$ & M & 2So & M1 & $\begin{array}{l}\text { 1.r.b. - } 2.5 \text { YR } \\
6 / 4\end{array}$ & $\begin{array}{l}\text { 1.r.b. - } 2.5 \text { YR } \\
6 / 4\end{array}$ & $\begin{array}{l}\text { 1.r.b. - } 2.5 \text { YR } \\
6 / 4\end{array}$ & 1 & $\mathrm{~W}$ \\
\hline 51 & 08.0415 & $\mathrm{~F} 20$ & $\begin{array}{l}\mathrm{D} / \\
\mathrm{C}\end{array}$ & M & 2So & I1 & r. - 2.5 YR 5/8 & r. - 2.5 YR 5/8 & r. - 2.5 YR 5/8 & 1 & $\mathrm{~W}$ \\
\hline 52 & 08.0802 & $\mathrm{~F} 20$ & $\begin{array}{l}\mathrm{D} / \\
\mathrm{C}\end{array}$ & $\mathrm{F}$ & 2So & M11 & r.br. - 5 YR 5/4 & r.br. - 5 YR 5/4 & r.br. - 5 YR 5/4 & 1 & $\mathrm{~W}$ \\
\hline 53 & 08.0792 & $\mathrm{~F} 20$ & $\begin{array}{l}\mathrm{D} / \\
\mathrm{C}\end{array}$ & $\mathrm{F}$ & 3So & M1 & $\begin{array}{l}\text { r. - } 10 \text { R 5/8; } \\
\text { r.br. - } 5 \text { YR 5/4 }\end{array}$ & r.br. - 5 YR 5/4 & r.br. - 5 YR 5/4 & 1 & $\mathrm{~W}$ \\
\hline 54 & 09.0298 & F16 & $\begin{array}{l}\mathrm{P} / \\
\mathrm{C}\end{array}$ & M & 2So & M2 & $\begin{array}{l}\text { l.r.b. - } 2.5 \text { YR } \\
6 / 4\end{array}$ & $\begin{array}{l}\text { l.r.b. - } 2.5 \text { YR } \\
6 / 4\end{array}$ & $\begin{array}{l}\text { l.r.b. - } 2.5 \text { YR } \\
6 / 4\end{array}$ & 1 & $\mathrm{~W}$ \\
\hline 55 & 09.0089 & $\mathrm{H} 18$ & $\begin{array}{l}\mathrm{P} / \\
\mathrm{C}\end{array}$ & M & 2So & M3 & $\begin{array}{l}\text { l.r.b. - } 2.5 \text { YR } 6 / 4 ; \\
\text { y.r. - } 5 \text { YR 5/6 }\end{array}$ & $\begin{array}{l}\text { 1.r.b. - } 2.5 \text { YR } 6 / 4 ; \\
\text { y.r. - } 5 \text { YR 5/6 }\end{array}$ & g. - 5 YR 5/1 & 1 & $\mathrm{~W}$ \\
\hline 56 & 09.0730 & H15 & $\begin{array}{l}\mathrm{P} / \\
\mathrm{C}\end{array}$ & M & 2So & M1 & $\begin{array}{l}\text { l.r.b. - } 5 \text { YR } 6 / 4 ; \\
\text { y.r. - } 5 \text { YR 5/4 }\end{array}$ & $\begin{array}{l}\text { 1.r.b. - } 5 \text { YR 6/4; } \\
\text { y.r. - } 5 \text { YR 5/4 }\end{array}$ & g. - 5 YR 5/1 & 1 & W \\
\hline 57 & 08.0764 & F19 & $\begin{array}{l}\mathrm{D} / \\
\mathrm{C}\end{array}$ & M & 2So & M11 & r. - 2.5 YR 5/6 & r. - 2.5 YR 5/6 & $\begin{array}{l}\text { r. - } 2.5 \text { YR 5/6; } \\
\text { g.g. - } 10 \text { Y 5/1 }\end{array}$ & 1 & $\mathrm{~W}$ \\
\hline 58 & 08.0362 & $\mathrm{~F} 20$ & $\begin{array}{l}\mathrm{D} / \\
\mathrm{C}\end{array}$ & M & 2So & M11 & 1.r. - 2.5 YR $6 / 6$ & 1.r. - 2.5 YR $6 / 6$ & $\begin{array}{l}\text { 1.r. - } 2.5 \text { YR 6/6; } \\
\text { g. - GLEY1 5/N }\end{array}$ & 1 & $\mathrm{~W}$ \\
\hline 59 & 09.0348 & G17 & $\begin{array}{l}\mathrm{P} / \\
\mathrm{C}\end{array}$ & M & 2So & M11 & $\begin{array}{l}\text { l.r.b. - } 2.5 \text { YR } \\
6 / 4\end{array}$ & $\begin{array}{l}\text { l.r.b. - } 2.5 \text { YR } \\
6 / 4\end{array}$ & $\begin{array}{l}\text { l.r.b. - } 2.5 \mathrm{YR} \\
6 / 4\end{array}$ & 1 & $\mathrm{~W}$ \\
\hline 60 & 08.1132 & TS & $\begin{array}{l}\mathrm{D} / \\
\mathrm{C}\end{array}$ & M & 2So & M11 & y.r. - 5 YR 5/6 & y.r. - 5 YR 5/6 & y.r. - 5 YR 5/6 & 1 & HW \\
\hline 61 & 08.1904 & $\mathrm{~L} 4, \mathrm{~b} 1$ & $\begin{array}{l}\mathrm{D} / \\
\mathrm{C}\end{array}$ & M & 3So & M9 & r. -2.5 YR 5/6 & $\begin{array}{l}\text { p. - } 5 \text { YR 7/4; } \\
\text { r. - } 2.5 \text { YR 5/6 }\end{array}$ & r. - 2.5 YR 5/6 & 1 & $\mathrm{~W}$ \\
\hline 62 & 08.2205 & $\mathrm{TS}$ & $\begin{array}{l}\mathrm{P} / \\
\mathrm{C}\end{array}$ & M & 3So & M11 & $\begin{array}{l}\text { p.r. - } 10 \text { R } 6 / 4 ; \\
\text { r.y. - } 5 \text { YR } 6 / 6\end{array}$ & $\begin{array}{l}\text { p.r. - } 10 \text { R } 6 / 4 ; \\
\text { r.y. - } 5 \text { YR } 6 / 6\end{array}$ & $\begin{array}{l}\text { r.y. - } 5 \text { YR 6/6; } \\
\text { d.g. - GLEY1 4/N }\end{array}$ & 1 & HW \\
\hline 63 & 08.2201 & TS & $\begin{array}{l}\mathrm{D} / \\
\mathrm{C}\end{array}$ & M & 2So & M5 & br. - 7.5 YR 5/3 & r.br. - 5 YR 5/3 & r.br. - 5 YR 5/3 & 1 & HW \\
\hline 64 & 09.0755 & H15 & $\begin{array}{l}\mathrm{P} / \\
\mathrm{C}\end{array}$ & $\mathrm{C}$ & $2 \mathrm{~B}$ & M17 & $\begin{array}{l}\text { br. - } 7.5 \text { YR 4/2; } \\
\text { br. - } 7.5 \text { YR 4/2 B }\end{array}$ & $\begin{array}{l}\text { r.br. - } 5 \text { YR 5/4; } \\
\text { y.r. - } 5 \text { YR 4/6 YR }\end{array}$ & d.g. - 10 YR 4/1 & 1 & HW \\
\hline 65 & 09.0106 & $\mathrm{H} 18$ & $\begin{array}{l}\mathrm{P} / \\
\mathrm{C}\end{array}$ & $\mathrm{MC}$ & 2So & M11 & $\begin{array}{l}\text { v.p.b. - } 10 \text { YR } \\
7 / 3\end{array}$ & $\begin{array}{l}\text { l.r.b. - } 2.5 \text { YR } \\
6 / 4\end{array}$ & $\begin{array}{l}\text { l.r.b. - } 2.5 \mathrm{YR} \\
6 / 4\end{array}$ & 1 & HW \\
\hline 66 & 09.0049 & H16 & $\mathrm{K} / \mathrm{K}$ & $\mathrm{MF}$ & 1 & M8 & $\begin{array}{l}\text { 1.r.b. - } 2.5 \text { YR } \\
6 / 4\end{array}$ & $\begin{array}{l}\text { 1.r.b. - } 2.5 \text { YR } \\
6 / 4\end{array}$ & $\begin{array}{l}\text { 1.r.b. - } 2.5 \text { YR } \\
6 / 4\end{array}$ & 1 & $\mathrm{H}$ \\
\hline 67 & 09.0279 & H17 & $\mathrm{K} / \mathrm{K}$ & $\mathrm{MC}$ & 2So & M15 & $\begin{array}{l}\text { r.br. - } 5 \text { YR 5/3; } \\
\text { y.r. - } 5 \text { YR 5/6 }\end{array}$ & $\begin{array}{l}\text { r.br. - } 5 \text { YR 5/3; } \\
\text { y.r. - } 5 \text { YR 5/6 }\end{array}$ & g. - 7.5 YR 5/1 & 1 & HW \\
\hline 68 & 08.2000 & $\mathrm{~L} 4, \mathrm{~b} 2$ & $\begin{array}{l}\mathrm{D} / \\
\mathrm{C}\end{array}$ & M & $3 \mathrm{~B}$ & M5 & y.r. - 5 YR 5/6 & y.r. - 5 YR 5/6 & y.r. - 5 YR 5/6 & 1 & HW \\
\hline
\end{tabular}



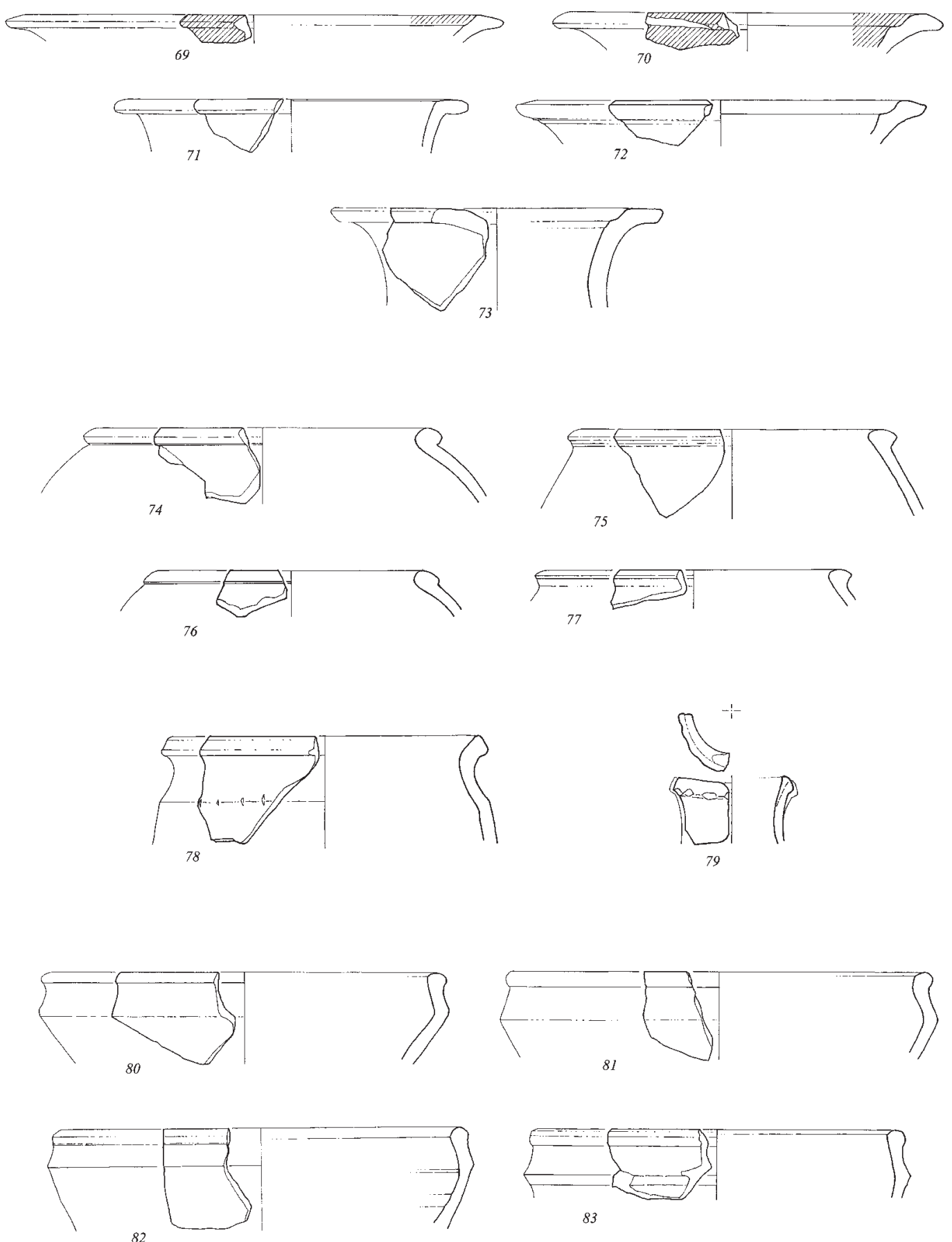

83

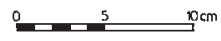

Fig. 21. Sherds dating to the Late Bronze Age/Iron Age. 
Fig. 21. Sherds dating to the Late Bronze Age/Iron Age.

\begin{tabular}{|c|c|c|c|c|c|c|c|c|c|c|c|}
\hline n. & UKn. & area & $\mathbf{W} / \mathbf{C l}$ & $\mathbf{E}$ & ST & $\mathbf{F a}$ & Color (out) & Color (in) & Color (sect.) & $\mathbf{A}$ & $\mathbf{T}$ \\
\hline 69 & 08.1284 & $\mathrm{~L} 2, \mathrm{~b} 3$ & $\begin{array}{l}\mathrm{RS} / \\
\mathrm{C}\end{array}$ & MF & $4 \mathrm{~B}$ & M11 & $\begin{array}{l}\text { r. - } 10 \text { YR 5/6; } \\
\text { br. - } 7.5 \text { YR 5/2 }\end{array}$ & $\begin{array}{l}\text { r. - } 10 \text { YR 5/6; } \\
\text { br. - } 7.5 \text { YR 5/2 }\end{array}$ & $\begin{array}{l}\text { br. - } 7.5 \text { YR 5/2; } \\
\text { y.r. - } 5 \text { YR 5/6 }\end{array}$ & 1 & W \\
\hline 70 & 08.1638 & $\mathrm{~L} 3, \mathrm{~b} 3$ & $\begin{array}{l}\mathrm{RS} / \\
\mathrm{C}\end{array}$ & M & $4 \mathrm{~B}$ & M11 & $\begin{array}{l}\text { w.r. - } 10 \text { R } 5 / 4 ; \\
\text { r.br. - } 5 \text { YR 4/4 }\end{array}$ & r.br. - 5 YR 4/4 & $\begin{array}{l}\text { r.br. - } 5 \text { YR 4/4; } \\
\text { d.g. - GLEY1 4/N }\end{array}$ & 1 & W \\
\hline 71 & 08.0920 & $\mathrm{~L} 1, \mathrm{~b} 3$ & $\begin{array}{l}\mathrm{P} / \\
\mathrm{C} \\
\end{array}$ & M & $4 \mathrm{~S}$ & M11 & $\begin{array}{l}\text { p. - } 7.5 \text { YR 7/3; } \\
\text { 1.r.b. - } 5 \text { YR 6/4 }\end{array}$ & 1.r.b. - 5 YR $6 / 4$ & 1.r.b. - 5 YR $6 / 4$ & 1 & $\mathrm{~W}$ \\
\hline 72 & 08.1311 & $\mathrm{~L} 2, \mathrm{~b} 4$ & $\begin{array}{l}\mathrm{P} / \\
\mathrm{C}\end{array}$ & M & $3 \mathrm{~S}$ & M11 & y.r. - 5 YR 5/6 & y.r. - 5 YR 5/6 & $\begin{array}{l}\text { p.g. - } 7.5 \text { YR } 6 / 2 ; \\
\text { y.r. - } 5 \text { YR } 5 / 6\end{array}$ & 1 & W \\
\hline 73 & 08.1900 & L3,b5 & $\begin{array}{l}\mathrm{P} / \\
\mathrm{C}\end{array}$ & $\mathrm{F}$ & $4 \mathrm{~S}$ & M11 & r. -2.5 YR 5/8 & r. - 2.5 YR 5/6 & $\begin{array}{l}\text { r. - } 2.5 \text { YR 5/6; } \\
\text { d.g. - GLEY1 4/N }\end{array}$ & 1 & W \\
\hline 74 & 08.772 & F19 & $\begin{array}{l}\mathrm{K} / \\
\mathrm{K} \\
\end{array}$ & M & $3 \mathrm{~S}$ & M3b & r.br. - 2.5 YR $5 / 3$ & r.br. - 2.5 YR $5 / 3$ & $\begin{array}{l}\text { r.br. - } 2.5 \text { YR 5/3; } \\
\text { r. - } 10 \text { R 5/8 }\end{array}$ & 1 & $\mathrm{~W}$ \\
\hline 75 & 08.1056 & $\mathrm{~L} 2, \mathrm{~b} 2$ & \begin{tabular}{|l|}
$\mathrm{K} /$ \\
$\mathrm{K}$ \\
\end{tabular} & M & $3 \mathrm{~S}$ & M3b & r.br. - 5 YR 5/4 & r.br. - 5 YR 5/4 & r.br. - 5 YR 5/4 & 1 & $\mathrm{~W}$ \\
\hline 76 & 09.0901 & E16 & $\mathrm{K} / \mathrm{K}$ & M & $2 \mathrm{~S}$ & M1 & p. - 5 YR 7/4 & p. - 5 YR 7/4 & y.r. - 5 YR 5/6 & 1 & W \\
\hline 77 & 09.0600 & H13 & $\mathrm{K} / \mathrm{K}$ & MF & $3 \mathrm{~S}$ & M2 & $\begin{array}{l}\text { p.b. - } 10 \text { YR } 6 / 3 ; \\
\text { br. - } 10 \text { YR } 5 / 3\end{array}$ & br. - 10 YR $5 / 3$ & d.g. - 10 YR 4/1 & 1 & $\mathrm{~W}$ \\
\hline 78 & 09.1172 & L-1,b5A & $\begin{array}{l}\mathrm{P} / \\
\mathrm{C}\end{array}$ & M & $2 \mathrm{~S}$ & M17 & $\begin{array}{l}\text { l.o.b. - } 2.5 \text { YR } 5 / 6 \text {; } \\
\text { o.y. - } 2.5 \text { YR } 6 / 8\end{array}$ & $\begin{array}{l}\text { r. - } 2.5 \text { YR 5/6; } \\
\text { l.r. - } 2.5 \text { YR 6/8 }\end{array}$ & g. - 5 YR 5/1 & 1 & W \\
\hline 79 & 09.0515 & G14 & $\begin{array}{l}\mathrm{P} / \\
\mathrm{C}\end{array}$ & M & 2So & M3 & $\begin{array}{l}\text { r. - } 2.5 \text { YR } 5 / 6 ; \\
\text { p. - } 7.5 \text { YR } 7 / 4\end{array}$ & $\begin{array}{l}\text { r. - } 2.5 \text { YR } 5 / 6 ; \\
\text { p. - } 7.5 \text { YR } 7 / 4\end{array}$ & g. - 7.5 YR 5/1 & 1 & $\mathrm{~W}$ \\
\hline 80 & 08.810 & $\mathrm{~F} 20$ & $\begin{array}{l}\mathrm{P} / \\
\mathrm{C}\end{array}$ & M & $2 \mathrm{~S}$ & M7 & d.r.g. - 5 YR 4/2 & d.r.g. - 5 YR 4/2 & d.r.g. - 5 YR 4/2 & 1 & $\mathrm{~W}$ \\
\hline 81 & 08.796 & $\mathrm{~F} 20$ & $\begin{array}{l}\mathrm{P} / \\
\mathrm{C}\end{array}$ & $\mathrm{F}$ & $3 \mathrm{~S}$ & M11 & $\begin{array}{l}\text { l.g. - } 10 \text { YR 7/2; } \\
\text { r.br. - } 5 \text { YR 5/4 }\end{array}$ & $\begin{array}{l}\text { l.g. - } 10 \text { YR 7/2; } \\
\text { r.br. - } 5 \text { YR 5/4 }\end{array}$ & r.br. - 5 YR 5/4 & 1 & $\mathrm{~W}$ \\
\hline 82 & 08.0311 & $\mathrm{~F} 20$ & $\begin{array}{l}\mathrm{P} / \\
\mathrm{C}\end{array}$ & M & 3 & M11 & 1.r.b. - 5 YR $6 / 4$ & y.r. - 5 YR 5/8 & $\begin{array}{l}\text { g. - } 5 \text { YR 5/1; } \\
\text { y.r. - } 5 \text { YR 5/8 }\end{array}$ & 1 & $\mathrm{~W}$ \\
\hline 83 & 08.1351 & $\mathrm{~L} 2, \mathrm{~b} 4$ & $\begin{array}{l}\mathrm{P} / \\
\mathrm{C}\end{array}$ & MF & 3 & M11 & g. - GLEY1 5/N & r.br. - 5 YR 5/4 & r.br. - 5 YR 5/4 & 1 & $\mathrm{~W}$ \\
\hline
\end{tabular}




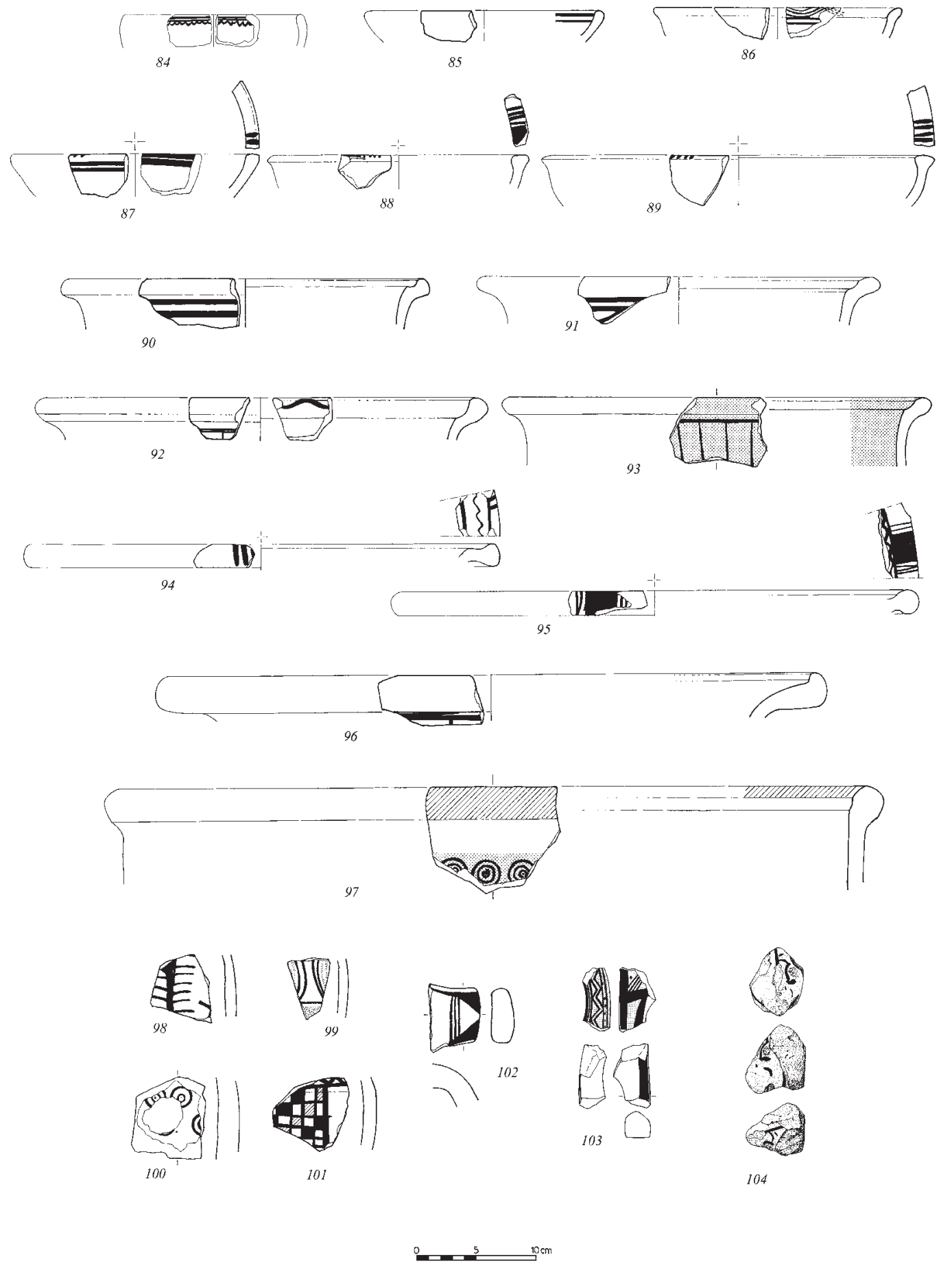

Fig. 22. Sherds dating to the Middle Iron Age. 
Fig. 22. Sherds dating to the Middle Iron Age.

\begin{tabular}{|c|c|c|c|c|c|c|c|c|c|c|c|}
\hline n. & UKn. & area & $\mathbf{W} / \mathbf{C l}$ & $\mathbf{E}$ & ST & Fa & Color (out) & Color (in) & Color (sect.) & $\mathbf{A}$ & $\mathbf{T}$ \\
\hline 84 & 09.0789 & H15 & $\mathrm{PT} / \mathrm{F}$ & MF & 4Bo & M3 & $\begin{array}{l}\text { br. - } 7.5 \text { YR } 4 / 2+ \\
\text { v.p.b. - } 10 \text { YR } 8 / 3\end{array}$ & $\begin{array}{l}\text { br. - } 7.5 \text { YR } 4 / 2+ \\
\text { v.p.b. - } 10 \text { YR } 8 / 3\end{array}$ & r.y. - 7.5 YR 6/6 & 1 & W \\
\hline 85 & 09.0368 & G17 & $\mathrm{PT} / \mathrm{C}$ & MF & $2 \mathrm{~B}$ & M3 & 1.b. - 7.5 YR $6 / 3$ & $\begin{array}{l}\text { d.r.g. }-2.5 \text { YR } 4 / 1+ \\
\text { l.b. - } 7.5 \text { YR } 6 / 4 \\
\end{array}$ & $7.5 \mathrm{YR} 5 / 4$ & 1 & $\mathrm{~W}$ \\
\hline 86 & 09.0528 & G14 & $\mathrm{PT} / \mathrm{C}$ & M & 4Bo & M15 & p.y. - 5 Y 8/2 & $\begin{array}{l}\text { d.r.g. - } 5 \text { YR } 4 / 2+ \\
\text { v.p.b. - } 10 \text { YR 7/3 }\end{array}$ & y.r. - 5 YR 5/6 & 1 & $\mathrm{~W}$ \\
\hline 87 & 09.0967 & L9 & $\mathrm{PT} / \mathrm{C}$ & MF & $3 \mathrm{~B}$ & M3B & $\begin{array}{l}\text { r.br. }-5 \text { YR } 4 / 3+ \\
\text { br. } 7.5 \text { YR } 5 / 3 \text {; } \\
\text { l.r. - } 10 \text { R } 6 / 6\end{array}$ & $\begin{array}{l}\text { r.br. }-5 \text { YR } 4 / 3+ \\
\text { g. }-10 \text { YR } 6 / 1 \text {; } \\
\text { d.r.g. } 10 \text { R } 4 / 1\end{array}$ & d.r.g. - 10 R 4/1 & 1 & W \\
\hline 88 & 08.0523 & G19 & $\begin{array}{l}\mathrm{PT} / \\
\mathrm{C}\end{array}$ & M & $4 \mathrm{~B}$ & M2 & $\begin{array}{l}\text { du.r. - } 10 \text { R } 3 / 2+ \\
\text { r.br. }-2.5 \text { YR } 5 / 4\end{array}$ & r.br. - 2.5 YR 5/4 & r.br. - 2.5 YR 5/4 & 1 & W \\
\hline 89 & 09.0107 & H18 & $\mathrm{PT} / \mathrm{F}$ & $\mathrm{F}$ & 4Bo & M10 & $\begin{array}{l}\text { W.r. - 2.5 YR } 4 / 2+ \\
\text { l.r. - } 2.5 \text { YR } 6 / 6\end{array}$ & 1.r. - 2.5 YR $6 / 6$ & 1.r. - 2.5 YR $6 / 6$ & 1 & W \\
\hline 90 & 09.0773 & H15 & $\mathrm{PT} / \mathrm{C}$ & MF & $4 S$ & M4 & $\begin{array}{l}\text { d.r.b. - } 10 \text { R } 3 / 1+ \\
\text { l.b. - } 7.5 \text { YR } 6 / 4\end{array}$ & 1.b. - 7.5 YR $6 / 4$ & r. -2.5 YR $5 / 8$ & 1 & W \\
\hline 91 & 08.2021 & $\mathrm{HM}$ & $\mathrm{PT} / \mathrm{C}$ & M & $4 \mathrm{~S}$ & M2 & $\begin{array}{l}\text { l.r.b. - } 5 \text { YR } 6 / 4+ \\
\text { l.r.b. - } 2.5 \text { YR } 6 / 4\end{array}$ & 1.r.b. - 2.5 YR $6 / 4$ & 1.r.b. - 2.5 YR $6 / 4$ & 1 & $\mathrm{~W}$ \\
\hline 92 & 09.0324 & F16 & $\mathrm{PT} / \mathrm{C}$ & MF & 3Bo & $\begin{array}{c}\text { M3 } \\
\text { B }\end{array}$ & $\begin{array}{l}\text { r.br. - } 5 \text { YR 5/4 + } \\
\text { l.b.g. - } 10 \text { YR 6/2; } \\
\text { g. - } 10 \text { YR 6/1 }\end{array}$ & $\begin{array}{l}\text { r.br. - } 5 \text { YR 5/4+ } \\
\text { l.b.g. - } 10 \text { YR 6/2; } \\
\text { g. - } 10 \text { YR 6/1 }\end{array}$ & br. - 7.5 YR 5/3 & 1 & W \\
\hline 93 & 09.0309 & F16 & $\begin{array}{l}\mathrm{PYS} / \\
\mathrm{C}\end{array}$ & M & 4Bo & M3 & $\begin{array}{l}\text { d.r.g. - } 5 \text { YR } 4 / 2+ \\
\text { r.y. - } 7.5 \text { YR } 7 / 6\end{array}$ & r.y. - 7.5 YR 7/6 & r.y. - 5 YR 6/6 & 1 & W \\
\hline 94 & 08.0548 & HM & $\begin{array}{l}\mathrm{PT} / \\
\mathrm{C}\end{array}$ & M & $4 \mathrm{P}$ & & $\begin{array}{l}\text { d.r.g. - } 5 \text { YR } 4 / 2+ \\
\text { l.r. }-2.5 \text { YR } 6 / 8\end{array}$ & $\begin{array}{l}\text { d.r.g. - } 5 \text { YR } 4 / 2+ \\
\text { l.r. - } 2.5 \text { YR } 6 / 6\end{array}$ & l.r. - 2.5 YR 6/6 & 1 & W \\
\hline 95 & 08.0680 & I19 & $\begin{array}{l}\mathrm{PT} / \\
\mathrm{C}\end{array}$ & $\mathrm{F}$ & $4 \mathrm{P}$ & M11 & $\begin{array}{l}\text { w.r. - } 10 \text { R } 4 / 2+ \\
\text { l.b. - } 7.5 \text { YR } 6 / 4 \text {; } \\
\text { l.r. - 2.5YR 6/8 }\end{array}$ & $\begin{array}{l}\text { w.r. - } 10 \mathrm{R} 4 / 2+ \\
\text { l.b. - } 7.5 \text { YR } 6 / 4 \text {; } \\
\text { l.r. - } 2.5 \text { YR } 6 / 8\end{array}$ & 1.r. - 2.5 YR $6 / 8$ & 1 & W \\
\hline 96 & 09.1105 & D9 & $\mathrm{PT} / \mathrm{C}$ & M & $4 \mathrm{~S}$ & M16 & $\begin{array}{l}\text { w.r. - } 2.5 \text { YR } 4 / 2+ \\
\text { p. - } 7.5 \text { YR } 7 / 4 ; \\
\text { r.y. - } 5 \text { YR } 6 / 6\end{array}$ & $\begin{array}{l}\text { w.r. - } 2.5 \text { YR } 4 / 2+ \\
\text { p. - } 7.5 \text { YR } 7 / 4 ; \\
\text { r.y. - } 5 \text { YR } 6 / 6\end{array}$ & 1.b. - 7.5 YR $6 / 4$ & 1 & W \\
\hline 97 & 09.0181 & G17 & $\mathrm{PT} / \mathrm{C}$ & M & 4Bo & M2 & $\begin{array}{l}\text { d.r.b. - } 2.5 \text { YR } 3 / 3+ \\
\text { v.p.b. - } 10 \text { YR } 8 / 3+ \\
\text { l.b. - } 7.5 \text { YR } 6 / 4 ; \\
\text { y.r. - } 5 \text { YR 5/6 }\end{array}$ & $\begin{array}{l}\text { l.b. - } 7.5 \text { YR } 6 / 4 ; \\
\text { y.r. - } 5 \text { YR 5/6 }\end{array}$ & g. - 5 YR 5/1 & 1 & W \\
\hline 98 & 08.1908 & $\mathrm{~L} 4, \mathrm{~b} 1$ & $\begin{array}{l}\mathrm{PT} / \\
\mathrm{C}\end{array}$ & $\mathrm{F}$ & $4 \mathrm{P}$ & M11 & $\begin{array}{l}\text { d.r.b. - } 5 \text { YR } 3 / 4+ \\
\text { l.b. - } 7.5 \text { YR } 6 / 4 ; \\
\text { r. - } 2.5 \text { YR 5/6 }\end{array}$ & r. -2.5 YR 5/6 & r. -2.5 YR 5/6 & 1 & $\mathrm{~W}$ \\
\hline 99 & 08.0549 & $\mathrm{TS}$ & $\begin{array}{l}\mathrm{PT} / \\
\mathrm{C}\end{array}$ & M & $4 \mathrm{P}$ & M3 & $\begin{array}{l}\text { r.br. - } 5 \text { YR } 4 / 4 \text {; } \\
\text { r.br. - } 5 \text { YR } 3 / 2+ \\
\text { v.p.b. - } 10 \text { YR 8/3; } \\
\text { l.r. - 2.5 YR 6/6 }\end{array}$ & 1.r. - 2.5 YR $6 / 6$ & 1.r. - 2.5 YR $6 / 6$ & 1 & W \\
\hline 100 & 08.2022 & $\mathrm{TS}$ & $\begin{array}{l}\mathrm{PT} / \\
\mathrm{C}\end{array}$ & M & $4 \mathrm{P}$ & M8 & $\begin{array}{l}\text { b. - } 10 \text { YR } 2 / 1+ \\
\text { v.p.b. - } 10 \text { YR } 8 / 2 ; \\
\text { r.y. }-5 \text { YR } 7 / 8\end{array}$ & 1.r.b. - 5 YR $6 / 3$ & $\begin{array}{l}\text { r.y. - } 5 \text { YR; } 6 / 6 \text {; } \\
\text { l.r.b. - } 5 \text { YR } 6 / 3\end{array}$ & 1 & $\mathrm{~W}$ \\
\hline 101 & 09.0081 & H16 & $\begin{array}{l}\mathrm{Pf} / \\
\mathrm{C}\end{array}$ & $\mathrm{C}$ & $4 \mathrm{~S}$ & M15 & $\begin{array}{l}\text { l.r.b. - } 2.5 \text { YR } 6 / 4 ; \\
\text { d.r.g. - } 2.5 \text { YR } 3 / 1+ \\
\text { p. - } 7.5 \text { YR } 8 / 3\end{array}$ & y.r. - 5YR 5/6 & y.r. - 5 YR 5/6 & 1 & $\mathrm{~W}$ \\
\hline 102 & 08.1903 & $\mathrm{~L} 4, \mathrm{~b} 1$ & $\begin{array}{l}\mathrm{PT} / \\
\mathrm{C}\end{array}$ & M & $4 \mathrm{P}$ & M8 & $\begin{array}{l}\text { v.d.g. - } 10 \text { YR 3/1 + } \\
\text { v.p.b. - } 10 \text { YR 8/3; } \\
\text { r.y. - } 5 \text { YR 6/6 }\end{array}$ & r.y. - 5 YR 6/6 & r.y. - 5 YR 6/6 & 1 & $\mathrm{H}$ \\
\hline 103 & 09.0598 & H13 & $\begin{array}{l}\text { PYS/ } \\
\text { C }\end{array}$ & M & $4 \mathrm{~B}$ & M3B & $\begin{array}{l}\text { d.g.b. - } 2.5 \text { YR } 4 / 2+ \\
\text { p.w. - } 10 \text { YR } 8 / 2 ; \\
\text { l.r. - 2.5 YR 6/6 }\end{array}$ & 1.r. - 2.5 YR $6 / 6$ & 1.r. - 2.5 YR $6 / 6$ & 1 & $\mathrm{H}$ \\
\hline 104 & 09.0899 & E16 & $\mathrm{PYS} / \mathrm{F}$ & MF & $4 \mathrm{~B}$ & M3 & $\begin{array}{l}\text { br. - } 10 \text { YR } 4 / 3 \text {; } \\
\text { r. - } 2.5 \text { YR } 5 / 8+ \\
\text { v.p.b. - } 10 \text { YR } 8 / 4 \text {; } \\
\text { l.r. - } 2.5 \text { YR } 7 / 8\end{array}$ & $\begin{array}{l}\text { p. - } 7.5 \text { YR } 7 / 3 \text {; } \\
\text { 1.r. - } 2.5 \text { YR } 7 / 8\end{array}$ & 1.r. - 2.5 YR $7 / 8$ & 1 & $\mathrm{H}$ \\
\hline
\end{tabular}




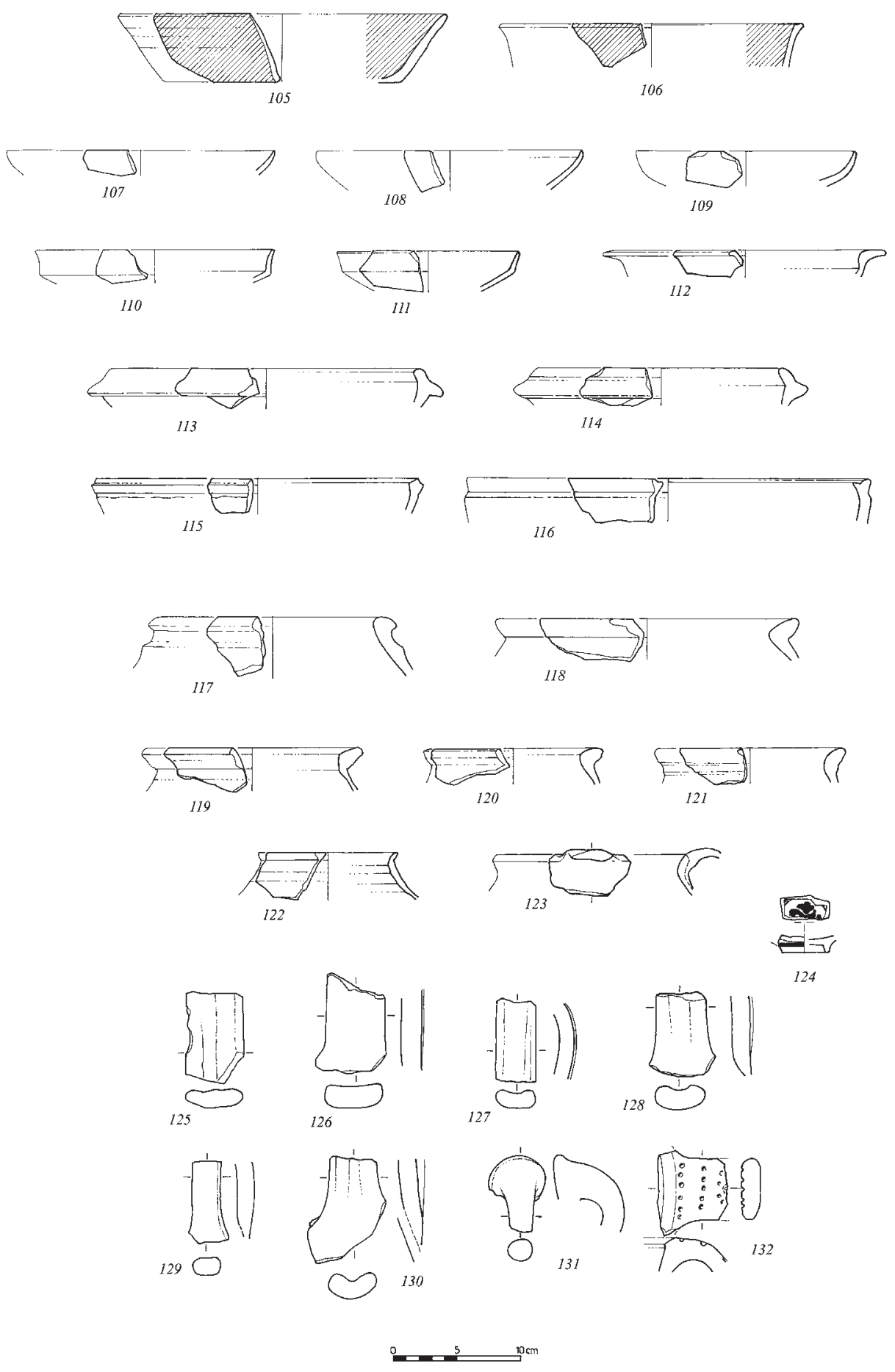

Fig. 23. Sherds dating to the 'later' period. 
Fig. 23. Sherds dating to the 'later' period.

\begin{tabular}{|c|c|c|c|c|c|c|c|c|c|c|c|}
\hline n. & UKn. & area & $\mathbf{W} / \mathbf{C l}$ & $\mathbf{E}$ & ST & $\mathbf{F a}$ & Color (out) & Color (in) & Color (sect.) & $\mathbf{A}$ & $\mathbf{T}$ \\
\hline 105 & 09.0944 & L9 & $\mathrm{OS} / \mathrm{F}$ & $\mathrm{FF}$ & 4Bo & M14 & 1.r. - 2.5 YR $6 / 8$ & & r.y. - 5 YR 6/6 & 1 & $\mathrm{~W}$ \\
\hline 106 & 09.0900 & E16 & $\mathrm{RS} / \mathrm{F}$ & $\mathrm{FF}$ & $4 S+B$ & M14 & $\begin{array}{l}\text { r.br. - } 2.5 \text { YR } \\
4 / 3 \text {; }\end{array}$ & $\begin{array}{l}\text { d.r. - 10R3/6; } \\
\text { r.y. - } 5 \text { YR 7/6 }\end{array}$ & r.y. - 5 YR 6/6 & 3 & W \\
\hline 107 & 09.1233 & D14 & $\mathrm{YS} / \mathrm{F}$ & $\mathrm{F}$ & $4 \mathrm{P}$ & M14 & p.y. - 2.5 Y $8 / 4$ & p.y. - 2.5 Y 8/4 & r.y. - 5 YR 6/6 & 2 & W \\
\hline 108 & 09.1213 & D14 & $\begin{array}{l}\mathrm{P} / \\
\mathrm{F}\end{array}$ & $\mathrm{F}$ & $2 \mathrm{~S}$ & M1 & p. - 7.5 YR $7 / 3$ & p. - 7.5 YR 7/3 & br. - 7.5 YR 5/4 & 1 & W \\
\hline 109 & 09.0069 & H16 & $\begin{array}{l}\mathrm{P} / \\
\mathrm{F}\end{array}$ & $\mathrm{F}$ & $2 \mathrm{~S}$ & M14 & 1.b. - 7.5 YR $6 / 3$ & 1.b. - 7.5 YR $6 / 3$ & 1.b. - 7.5 YR $6 / 4$ & 1 & W \\
\hline 110 & 08.2206 & F20 & $\mathrm{RS} / \mathrm{F}$ & $\mathrm{F}$ & 4B & M7 & r. - 5 R 5/6 & 1.r. - 2.5 YR $6 / 6$ & $\begin{array}{l}\text { 1.r. - } 2.5 \text { YR 6/6; } \\
\text { r.g. - } 2.5 \text { YR 5/1 }\end{array}$ & 1 & W \\
\hline 111 & 09.1140 & $\mathrm{~L}-1,2 \mathrm{~A}$ & $\mathrm{RS} / \mathrm{F}$ & $\mathrm{F}$ & 4Bo & $\begin{array}{c}\text { M1 } \\
\text { V }\end{array}$ & $\begin{array}{l}\text { l.r. - } 10 \text { R } 6 / 6 ; \\
\text { r. - } 2.5 \text { YR 5/8 }\end{array}$ & $\begin{array}{l}\text { 1.r. - } 10 \text { R } 6 / 6 ; \\
\text { r. - } 2.5 \text { YR 5/8 }\end{array}$ & g. - GLEY1 5/N & 1 & W \\
\hline 112 & 09.0615 & H13 & $\begin{array}{l}\mathrm{P} / \\
\mathrm{C}\end{array}$ & $\mathrm{F}$ & $2 \mathrm{~S}$ & M1 & 1.b. - 7.5 YR $6 / 4$ & 1.b. - 7.5 YR $6 / 4$ & r.y. - 5 YR 6/6 & 1 & W \\
\hline 113 & 09.1056 & L11 & $\begin{array}{l}\mathrm{P} / \\
\mathrm{C}\end{array}$ & $\mathrm{MC}$ & 3So & M1 & $\begin{array}{l}\text { v.p.b. - } 10 \mathrm{YR} \\
7 / 3 \text {; }\end{array}$ & $\begin{array}{l}\text { 1.r. - } 2.5 \text { YR 6/6; } \\
\text { g. - } 5 \text { YR 5/1 }\end{array}$ & g. - 5 YR 5/1 & 1 & W \\
\hline 114 & 09.0019 & H16 & $\begin{array}{l}\mathrm{P} / \\
\mathrm{C}\end{array}$ & M & 2So & M2 & 1.r. - 2.5 YR $6 / 6$ & 1.r. - 2.5 YR $6 / 6$ & 1.r. - 2.5 YR 6/6 & 1 & W \\
\hline 115 & 09.0802 & G13 & $\begin{array}{l}\mathrm{P} / \\
\mathrm{C}\end{array}$ & M & $2 \mathrm{~S}$ & M2 & $\begin{array}{l}\text { br. - } 7.5 \text { YR } 5 / 2 \text {; } \\
\text { br. - } 7.5 \text { YR 5/3 }\end{array}$ & $\begin{array}{l}\text { br. - } 7.5 \text { YR } 5 / 2 ; \\
\text { br. - } 7.5 \text { YR } 5 / 3\end{array}$ & d.g. - 7.5 YR 4/1 & 1 & W \\
\hline 116 & 09.0988 & L8 & $\begin{array}{l}\mathrm{P} / \\
\mathrm{C}\end{array}$ & MF & 2Bo & M1 & $\begin{array}{l}\text { r. - } 2.5 \text { YR 5/6; } \\
\text { l.r. - } 2.5 \text { YR 6/6 }\end{array}$ & $\begin{array}{l}\text { 1.r. - } 2.5 \text { YR } 7 / 6 \text {; } \\
\text { l.r. - } 2.5 \text { YR } 6 / 6\end{array}$ & r.g. - 10 R 6/1 & 1 & W \\
\hline 117 & 08.0618 & K19 & $\mathrm{K}$ & $\mathrm{MF}$ & & M3b & $\begin{array}{l}\text { d.r.g. - } 2.5 \text { YR } \\
3 / 1\end{array}$ & $\begin{array}{l}\text { d.r.g. - } 2.5 \text { YR } \\
3 / 1\end{array}$ & $\begin{array}{l}\text { d.r.g. - } 2.5 \text { YR } \\
3 / 1\end{array}$ & 1 & $\mathrm{~W}$ \\
\hline 118 & 09.0839 & F14 & $\begin{array}{l}\mathrm{P} / \\
\mathrm{C}\end{array}$ & M & $3 \mathrm{~S}$ & $\begin{array}{c}\text { M3 } \\
\text { B }\end{array}$ & r.y. - 7.5 YR 7/4 & r.y. - 7.5 YR 7/4 & r. -2.5 YR 5/6 & 1 & $\mathrm{~W}$ \\
\hline 119 & 09.0226 & G15 & $\mathrm{PB} / \mathrm{C}$ & M & 3So & M3 & $\begin{array}{l}\text { r.b. - } 2.5 \text { YR } 5 / 3 ; \\
\text { l.r. - } 2.5 \text { YR } 6 / 6\end{array}$ & 1.r. - 2.5 YR $6 / 6$ & 1.r. - 2.5 YR $6 / 8$ & 1 & $\mathrm{~W}$ \\
\hline 120 & 09.0241 & G15 & $\begin{array}{l}\mathrm{P} / \\
\mathrm{C}\end{array}$ & M & 3So & M3 & 1.r. - 10 R $6 / 6$ & 1.r. - 10 R $7 / 6$ & 1.r. - 2.5 YR $6 / 8$ & 1 & $\mathrm{~W}$ \\
\hline 121 & 09.0878 & F15 & $\begin{array}{l}\mathrm{P} / \\
\mathrm{C}\end{array}$ & M & $1 \mathrm{~S}$ & M4 & p. -5 YR $7 / 3$ & r.y. - 5 YR 7/6 & r.g. - 5 YR 5/2 & 1 & W \\
\hline 122 & 09.0182 & G17 & $\begin{array}{l}\mathrm{P} / \\
\mathrm{C}\end{array}$ & $\mathrm{F}$ & 3Bo & M10 & r.y. - 7.5 YR 6/6 & r.y. - 5 YR 7/6 & r.br. - 5 YR 5/4 & 1 & W \\
\hline 123 & 09.0855 & F14 & $\mathrm{PB} / \mathrm{K}$ & $\mathrm{MF}$ & 1 & M15 & r.br. - 2.5 YR 5/4 & r.br. - 2.5 YR 5/4 & $\begin{array}{l}\text { d.r.g. - } 2.5 \text { YR } \\
4 / 1\end{array}$ & 1 & $\mathrm{~W}$ \\
\hline 124 & 09.0960 & L9 & $\mathrm{GL} / \mathrm{F}$ & $\mathrm{F}$ & 5 & M & white and blue & white and blue & white & 1 & W \\
\hline 125 & 09.0947 & L9 & $\begin{array}{l}\mathrm{P} / \\
\mathrm{C}\end{array}$ & MF & $2 \mathrm{~S}$ & M1 & r.y. - 7.5 YR 7/6 & r.y. - 7.5 YR 7/6 & 1.r. - 10 R $6 / 6$ & 1 & $\mathrm{H}$ \\
\hline 126 & 09.0163 & F17 & $\begin{array}{l}\mathrm{P} / \\
\mathrm{C}\end{array}$ & M & $2 \mathrm{~S}$ & M3 & $\begin{array}{l}\text { r.y. - } 7.5 \text { YR 7/6; } \\
\text { br. - 7.5 YR 5/4 }\end{array}$ & $\begin{array}{l}\text { r.y. - } 7.5 \text { YR } 7 / 6 ; \\
\text { b. - } 7.5 \text { YR 5/4 }\end{array}$ & g. - GLEY1 6/N & 1 & $\mathrm{H}$ \\
\hline 127 & 09.0172 & F17 & $\begin{array}{l}\mathrm{P} / \\
\mathrm{C}\end{array}$ & MF & 2So & M1 & 1.b. - 7.5 YR $6 / 3$ & br. - 7.5 YR 5/2 & 1.g. - 7.5 YR 7/1 & 1 & $\mathrm{H}$ \\
\hline 128 & 09.0948 & L9 & $\begin{array}{l}\mathrm{P} / \\
\mathrm{C}\end{array}$ & M & $2 \mathrm{~S}$ & M11 & 1.r. - 2.5 YR $6 / 6$ & 1.r. - 2.5 YR $6 / 6$ & r. - 2.5 YR 5/8 & 1 & $\mathrm{H}$ \\
\hline 129 & 09.0230 & G15 & $\begin{array}{l}\mathrm{P} / \\
\mathrm{C}\end{array}$ & $\mathrm{M}$ & $2 \mathrm{~S}$ & M3 & 1.r.b. - 5 YR $6 / 4$ & 1.r.b. - 5 YR $6 / 4$ & 1.r. - 2.5 YR $6 / 8$ & 1 & $\mathrm{H}$ \\
\hline 130 & 09.0328 & F16 & $\begin{array}{l}\mathrm{P} / \\
\mathrm{C}\end{array}$ & M & 2So & $\begin{array}{c}\text { M3 } \\
\text { B }\end{array}$ & br. - 7.5 YR 5/2 & 1.r. - 7.5 YR $5 / 2$ & g. - 7.5 YR 5/1 & 1 & $\mathrm{H}$ \\
\hline 131 & 09.0208 & G15 & $\begin{array}{l}\mathrm{P} / \\
\mathrm{C}\end{array}$ & M & 4So & M1 & $\begin{array}{l}\text { p. - } 10 \text { YR } 8 / 3+ \\
\text { l.b. - } 7.5 \text { YR } 6 / 3\end{array}$ & 1.b. -7.5 YR $6 / 3$ & y.b. - 10 YR 5/4 & 1 & $\mathrm{H}$ \\
\hline 132 & 09.1185 & $\mathrm{HM}$ & $\begin{array}{l}\mathrm{P} / \\
\mathrm{C}\end{array}$ & M & $2 \mathrm{~S}$ & M1 & w.r. - 10 R 4/4 & w.r. - 10 R 4/4 & w.r. - 10 R 4/4 & 1 & $\mathrm{H}$ \\
\hline
\end{tabular}



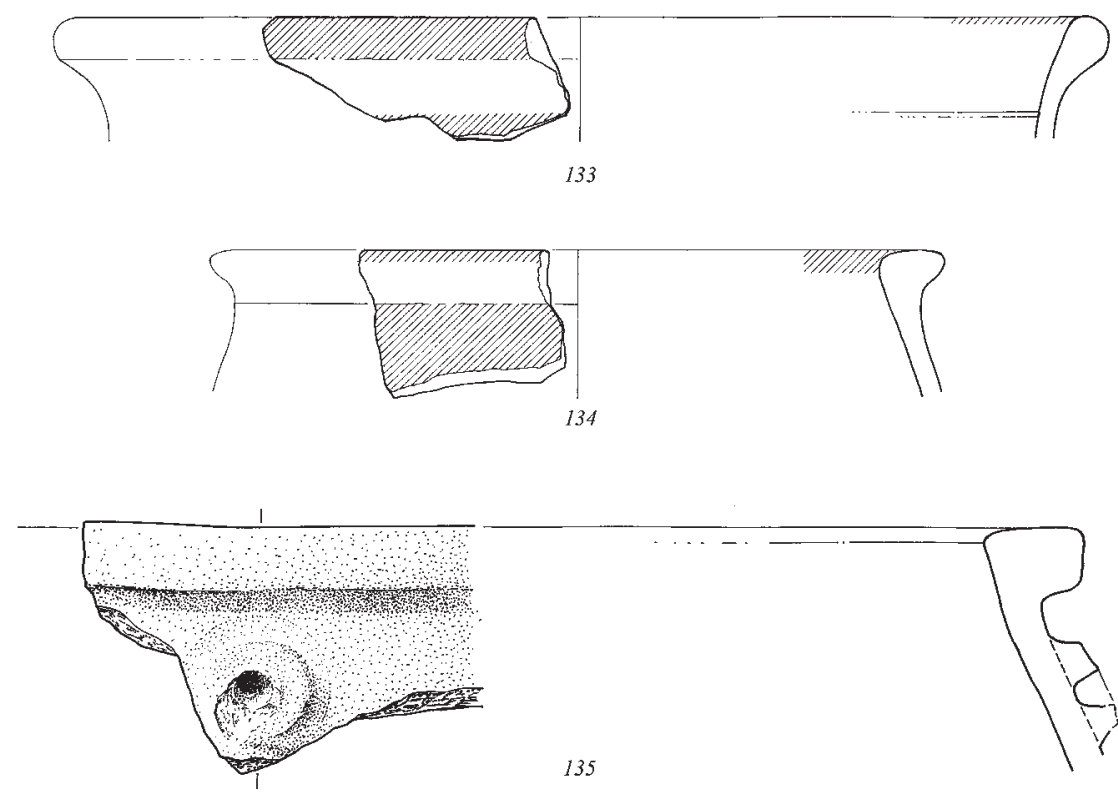

135
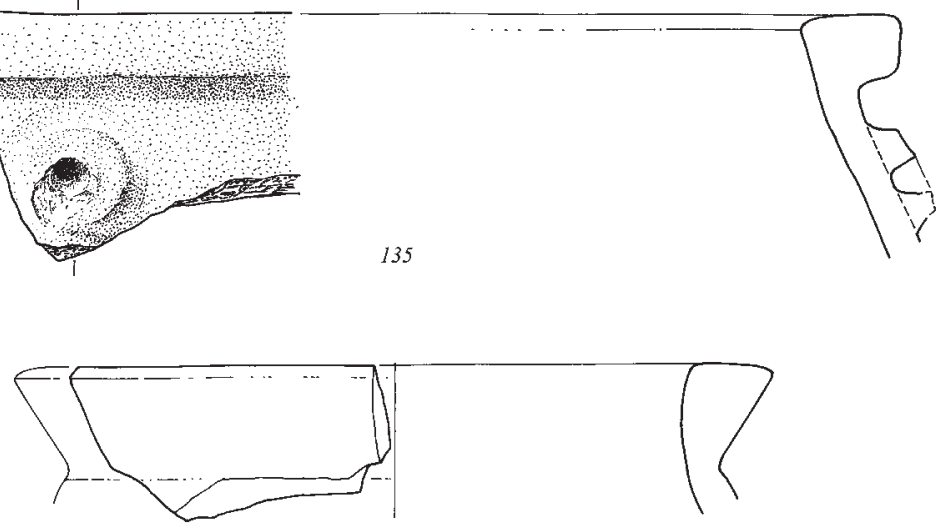

136
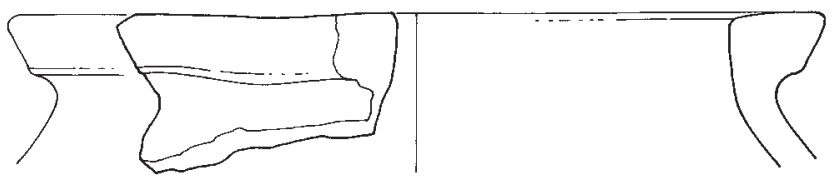

137
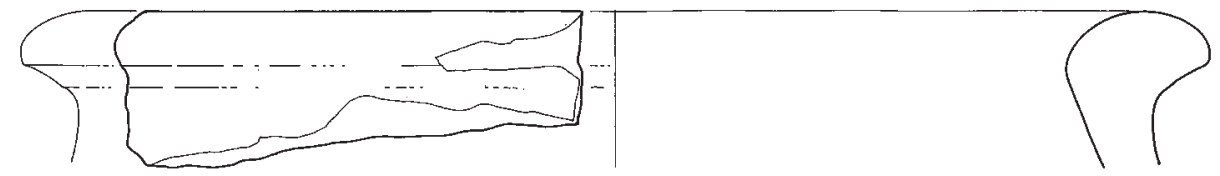

138

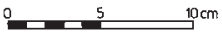

Fig. 24. Storage jar sherds. 
Fig. 24. Storage jar sherds.

\begin{tabular}{|c|c|c|c|c|c|c|c|c|c|c|c|}
\hline n. & UKn. & area & $\mathbf{W} / \mathbf{C l}$ & $\mathbf{E}$ & ST & $\mathbf{F a}$ & Color (out) & Color (in) & Color (sect.) & $\mathbf{A}$ & $T$ \\
\hline 133 & 09.0158 & F17 & $\mathrm{PT} / \mathrm{C}$ & M & 2Bo & M1 & $\begin{array}{l}\text { r. - } 10 \text { R } 5 / 6+ \\
\text { l.b. - } 7.5 \text { YR } 6 / 4\end{array}$ & 1.r. - 2.5 YR 6/6 & 1.r.b. - 2.5 YR $6 / 4$ & 1 & W \\
\hline 134 & 08.1026 & $\mathrm{~L} 2, \mathrm{~b} 1$ & $\begin{array}{l}\mathrm{RS} / \\
\mathrm{S}\end{array}$ & M & $4 \mathrm{~B}$ & M5 & $\begin{array}{l}\text { r. - } 10 \text { R 5/6; } \\
\text { 1.r. - } 2.5 \text { YR 6/8 }\end{array}$ & $\begin{array}{l}\text { r. - } 10 \text { R 5/6; } \\
\text { 1.r. - } 2.5 \text { YR 6/8 }\end{array}$ & 1.r. - 2.5 YR $6 / 8$ & 1 & W \\
\hline 135 & 09.0004 & $\mathrm{~L} 1, \mathrm{~b} 2$ & $\begin{array}{l}\mathrm{P} / \\
\mathrm{S}\end{array}$ & $\mathrm{MC}$ & $4 \mathrm{~S}$ & M3 & 1.b. - 7.5 YR $6 / 4$ & 1.b. - 7.5 YR $6 / 3$ & br. - 7.5 YR 5/4 & 1 & HW \\
\hline 136 & 09.0152 & F17 & PS & M & 2So & M8 & 1.b. - 7.5 YR $6 / 3$ & br. - 7.5 YR 5/2 & 1.r. - 2.5 YR $6 / 8$ & 1 & W \\
\hline 137 & 09.0983 & L8 & $\begin{array}{l}\mathrm{P} / \\
\mathrm{S}\end{array}$ & M & $2 \mathrm{~S}$ & M1 & 1.b. - 7.5 YR $6 / 4$ & 1.b. - 7.5 YR $6 / 4$ & g. - 7.5 YR 5/1 & 1 & W \\
\hline 138 & 09.0898 & E16 & $\begin{array}{l}\mathrm{C} / \\
\mathrm{S}\end{array}$ & $\mathrm{MC}$ & $3 \mathrm{~S}$ & M9 & r.g. - 10 R 6/1 & p. - 7.5 YR $7 / 4$ & g. - 7.5 YR 5/1 & 1 & HW \\
\hline
\end{tabular}

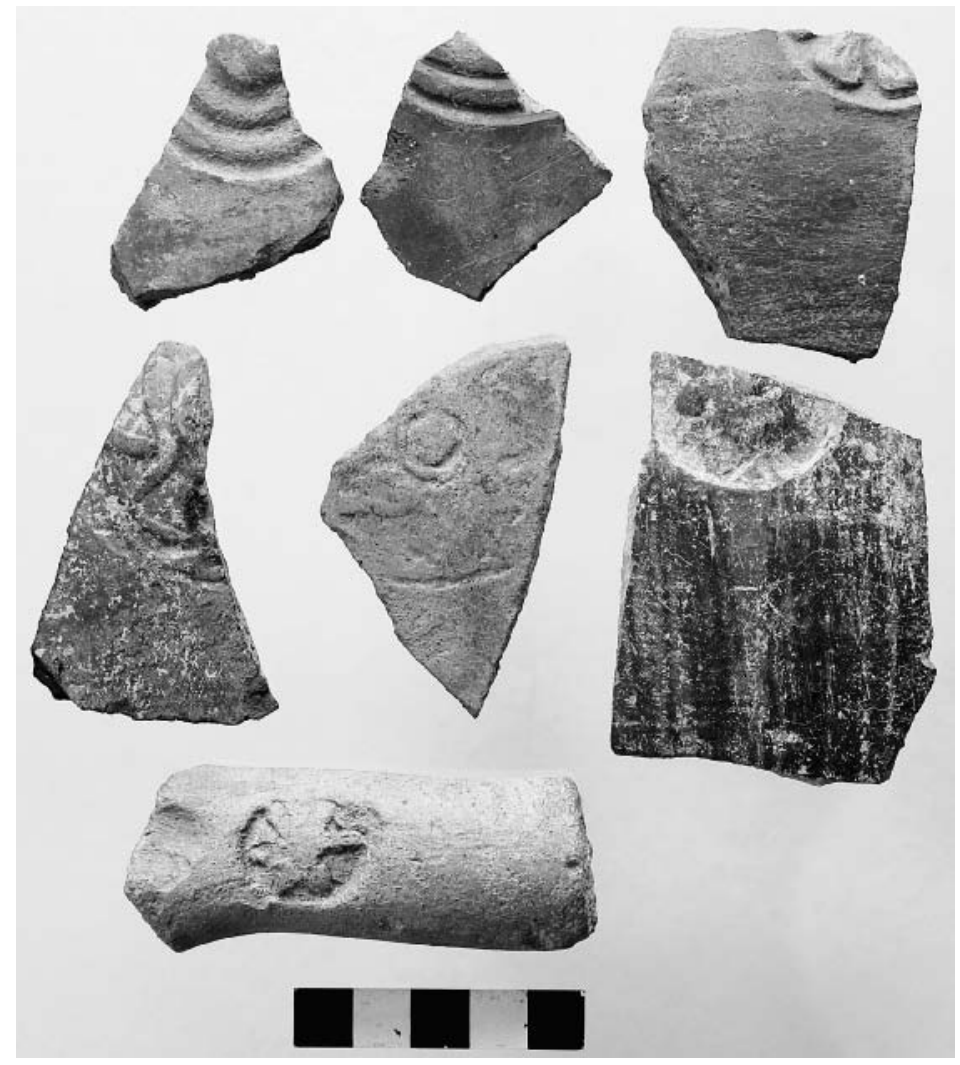

Fig. 25. Stamped sherds. 

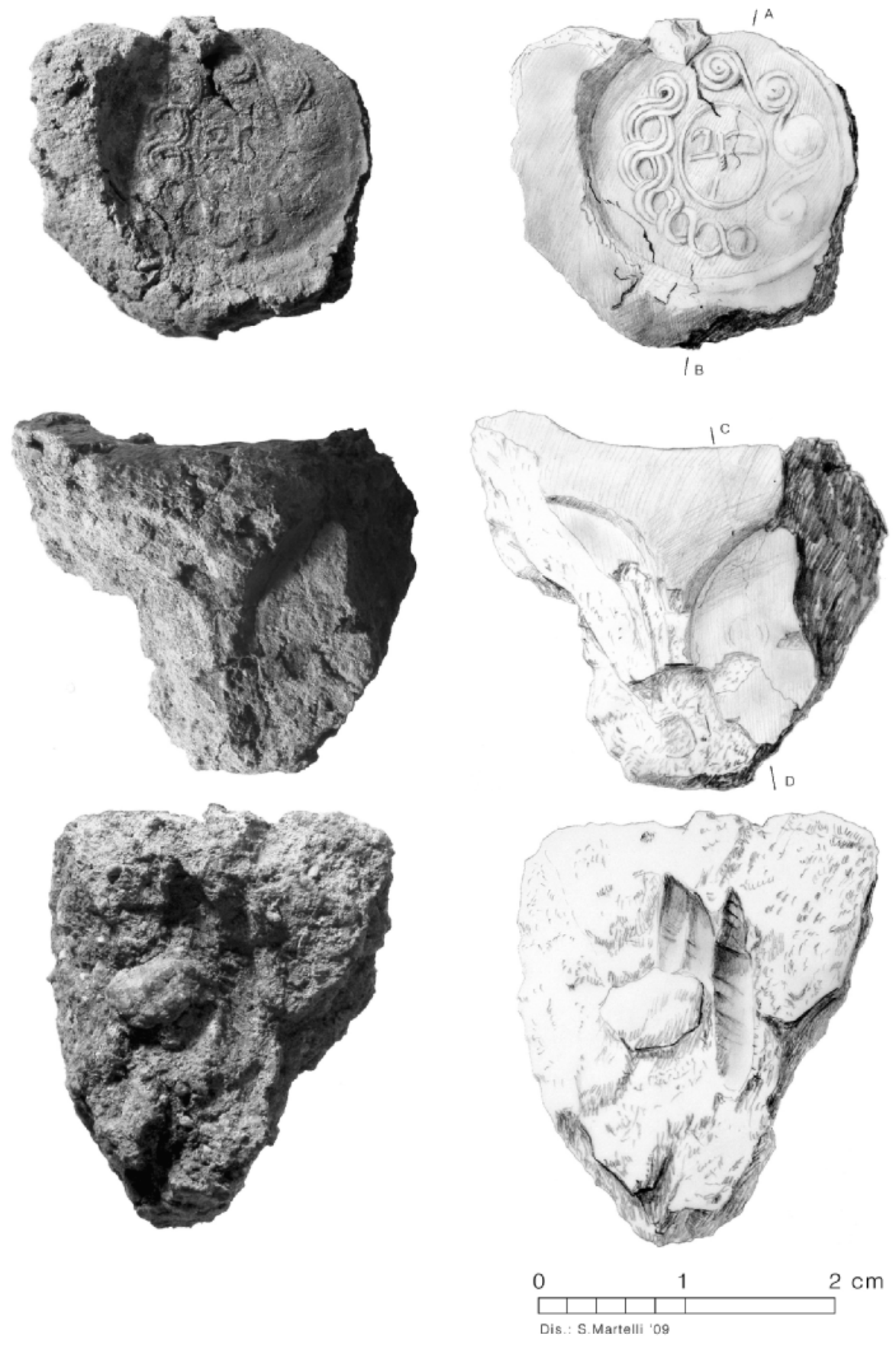

Fig. 26. The clay bulla UK09.Ob.1 (drawing by S. Martelli). 

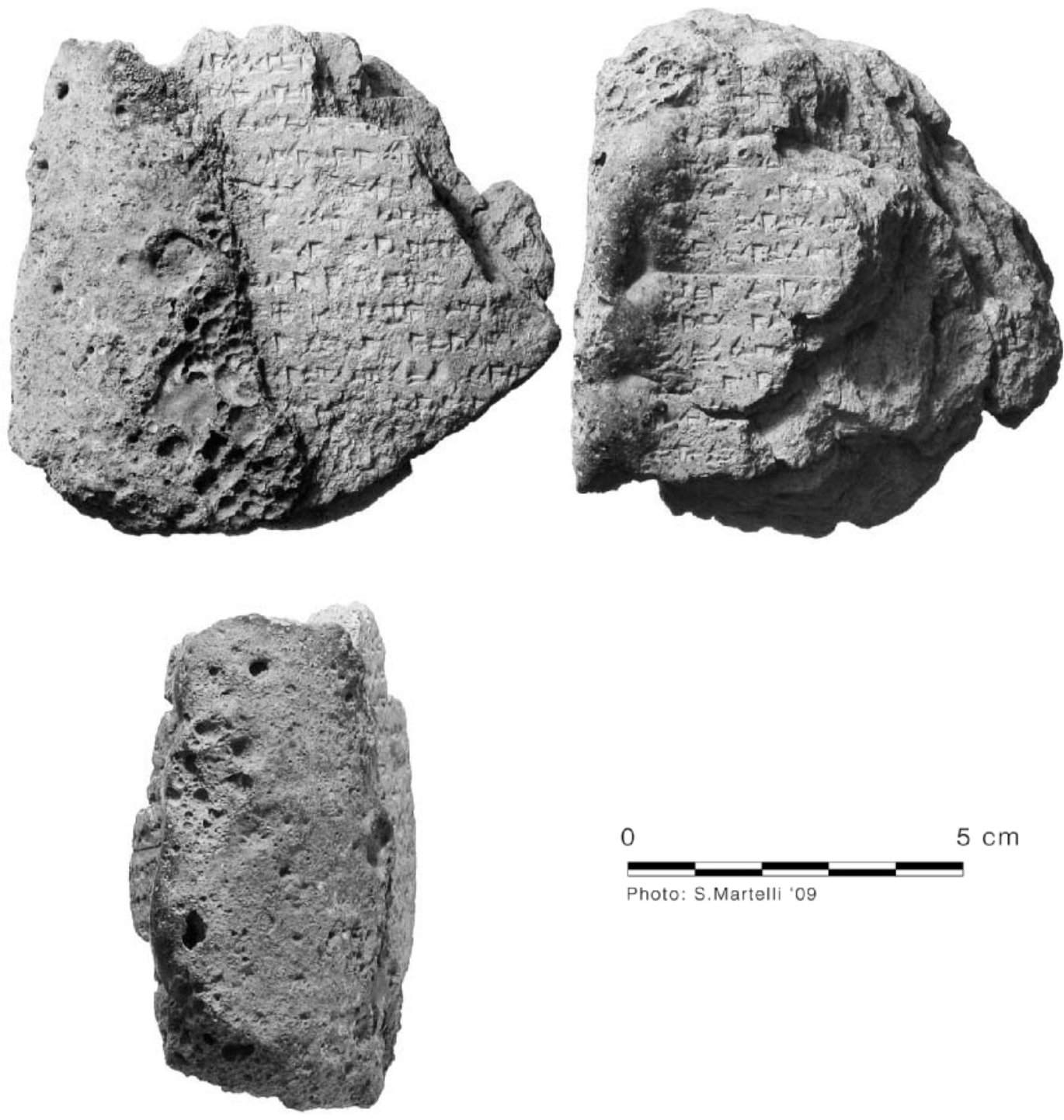

$5 \mathrm{~cm}$

Fig. 27. Obverse, reverse and edge of the tablet UK09.Ob.2. 